\title{
Evaluation of Polychlorinated Biphenyls ": OAK in Fish and SPMDs Near the U.S. Department of Energy Kansas City Plant
}
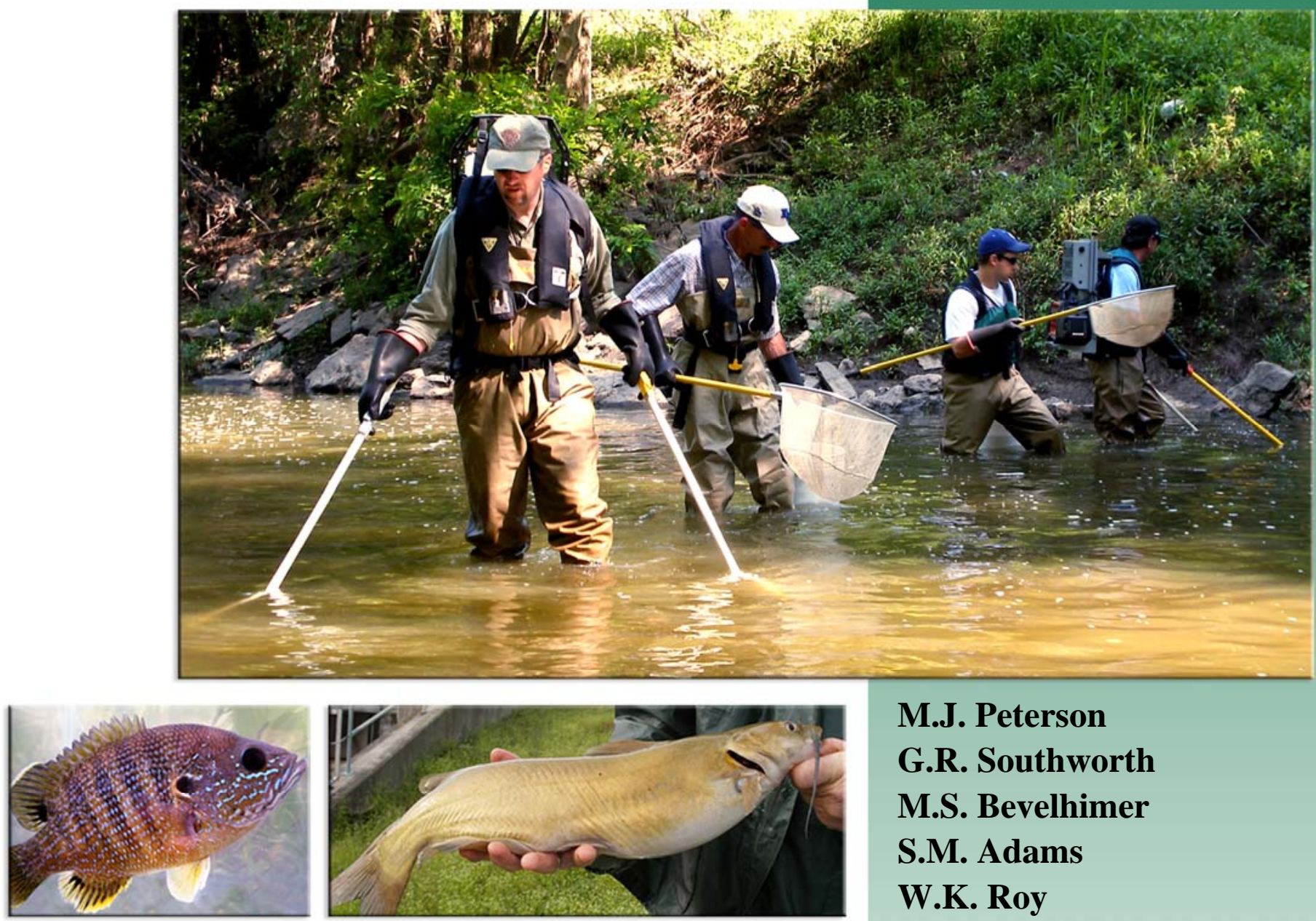

M.J. Peterson

G.R. Southworth

M.S. Bevelhimer

S.M. Adams

W.K. Roy

C.A. Roy

M. Stites

December 2008

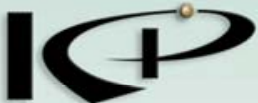




\section{DOCUMENT AVAILABILITY}

Reports produced after January 1, 1996, are generally available free via the U.S. Department of Energy (DOE) Information Bridge.

Web site http://www.osti.gov/bridge

Reports produced before January 1, 1996, may be purchased by members of the public from the following source.

National Technical Information Service

5285 Port Royal Road

Springfield, VA 22161

Telephone 703-605-6000 (1-800-553-6847)

TDD 703-487-4639

Fax 703-605-6900

E-mail info@ntis.fedworld.gov

Web site http://www.ntis.gov/support/ordernowabout.htm

Reports are available to DOE employees, DOE contractors, Energy Technology Data Exchange (ETDE) representatives, and International Nuclear Information System (INIS) representatives from the following source.

Office of Scientific and Technical Information

P.O. Box 62

Oak Ridge, TN 37831

Telephone 865-576-8401

Fax 865-576-5728

E-mail reports@adonis.osti.gov

Web site http://www.osti.gov/contact.html

This report was prepared as an account of work sponsored by an agency of the United States Government. Neither the United States Government nor any agency thereof, nor any of their employees, makes any warranty, express or implied, or assumes any legal liability or responsibility for the accuracy, completeness, or usefulness of any information, apparatus, product, or process disclosed, or represents that its use would not infringe privately owned rights. Reference herein to any specific commercial product, process, or service by trade name, trademark, manufacturer, or otherwise, does not necessarily constitute or imply its endorsement, recommendation, or favoring by the United States Government or any agency thereof. The views and opinions of authors expressed herein do not necessarily state or reflect those of the United States Government or any agency thereof. 


\title{
EVALUATION OF POLYCHLORINATED BIPHENYLS IN FISH AND SPMDS NEAR THE U.S. DEPARTMENT OF ENERGY'S KANSAS CITY PLANT
}

\author{
Mark J. Peterson \\ George R. Southworth \\ Mark S. Bevelhimer \\ S. Marshall Adams \\ W. Kelly Roy \\ Craig A. Roy \\ Environmental Sciences Division \\ Oak Ridge National Laboratory \\ Mike Stites \\ U.S. Department of Energy \\ Kansas City Plant
}

Date Published: December 2008

Prepared for

U.S. Department of Energy

Kansas City Plant

\author{
Prepared by \\ OAK RIDGE NATIONAL LABORATORY \\ Oak Ridge, Tennessee 37831 \\ managed by \\ UT-BATTELLE, LLC \\ for the \\ U.S. DEPARTMENT OF ENERGY \\ under contract DE-AC05-00OR22725
}





\section{CONTENTS}

LIST OF FIGURES

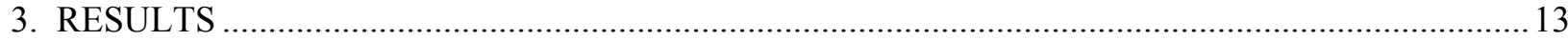

3.1 FISH

3.2 SEMIPERMEABLE MEMBRANE DEVICES (SPMDS) ........................................................ 16

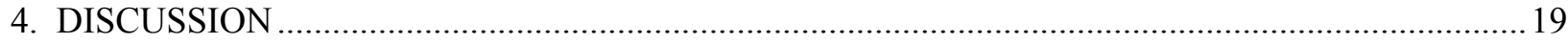

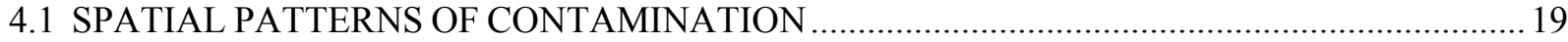

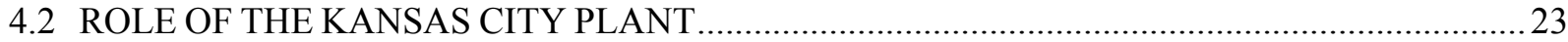

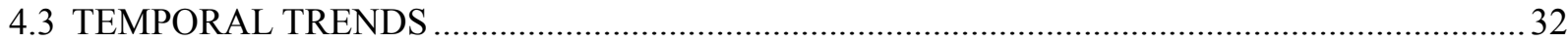

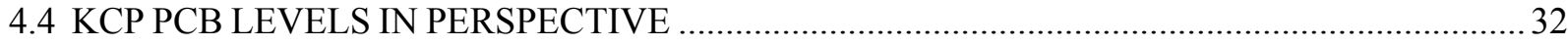

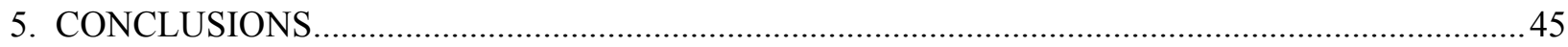

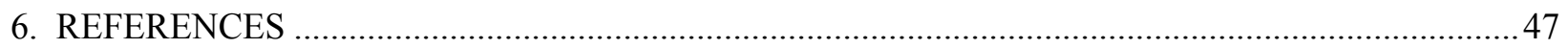

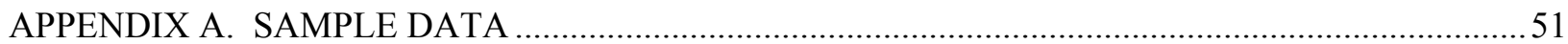

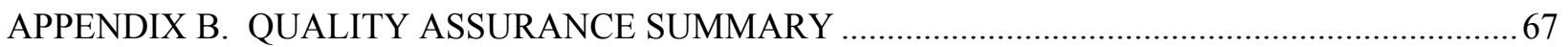





\section{LIST OF FIGURES}

Fig. 1. Location of the Kansas City Plant in relation to local waters and major roads.

Fig. 2. Fish and semi-permeable membrane device (SPMD) sampling locations near the Kansas

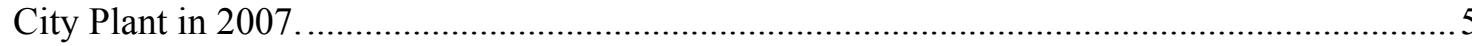
5

Fig. 3. Targeted fish species collected from stream and river sites near the Kansas City Plant: green sunfish (Lepomis cyanellus; top) and channel catfish (Ictalurus punctatus; bottom). ................ 7

Fig. 4. SPMD locations for the April-May 2008 deployment in Boone Creek and outfall 001.............8

Fig. 5. Semi-permeable membrane devices (SPMDs) are comprised of polyethylene tubes containing a layer of triolein oil (left) and are deployed by wrapping around a test tube rack and caged to help prevent damage from debris or biota during deployment (right, top and bottom)...............

Fig. 6. Plot of PCB congener concentration for each species pair (catfish versus sunfish) for each

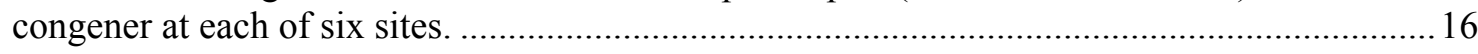

Fig. 7. Spatial pattern of mean PCB (Aroclor 1248/1254/1260) concentrations (ug/g) in green sunfish (top graph) and channel catfish (bottom graph), Indian Creek and the Blue River, 2007.

Fig. 8. Mean concentrations ( $\mu \mathrm{g} / \mathrm{g}$ ) of PCBs (Aroclor 1248,1254, and 1260) in green sunfish, June 2007.

Fig. 9. Mean concentrations $(\mu \mathrm{g} / \mathrm{g}$ ) of PCBs (Aroclor 1248, 1254, 1260) in channel catfish, June 2007.

Fig. 10. Difference in PCB congener concentrations in catfish (blue) and sunfish (yellow) between BLK 26 and BLK 31.

Fig. 11. Difference in PCB congener concentrations in catfish (blue) and sunfish (yellow) between ICK 0.2 and ICK 3.0.....

Fig. 12. Difference in PCB congener concentrations in catfish (blue) and sunfish (yellow) between ICK 0.2 and ICK 1.0 .

Fig. 13. Plot of principle components 1 and 2 for 53 catfish (circles) and 52 sunfish (plus signs samples based on 20 of the most common PCB congeners.

Fig. 14. Plot of the first two principle component scores for 52 sunfish from 6 sites. .28

Fig. 15. Plot of the first two principle component scores for 53 catfish from 6 sites. .28

Fig. 16. Plot of the first two principle component scores for sunfish and catfish from three Blue River sites (BLK 25, 27, and 31). 


\section{LIST OF FIGURES (cont'd)}

Fig. 17. Plot of the first two principle component scores for sunfish and catfish from three Indian Creek sites (ICK 0.2, 1.0, and 3.0).

Fig. 18. Plot of the first two principle components derived from 40 PCB congeners analyzed from SPMDs at 10 locations. 30

Fig. 19. Plot of the second and third principle components derived from 40 PCB congeners analyzed from SPMDs at 10 locations.

Fig. 20. Temporal changes in mean total PCB concentrations in green sunfish in Indian Creek at sites upstream (ICK 3.0) and downstream of outfall 003/004 (ICK 1.0) at the U.S. Dept. of Energy Kansas City Plant, 1991- 2007.

Fig. 21. Temporal changes in mean total PCB concentrations in green sunfish in Indian Creek at ICK 0.2, downstream of outfall 002 at the U.S. Dept. of Energy Kansas City Plant, 1991- 2007.

Fig. 22. Changes in mean total PCB concentrations in channel catfish at the lowermost Indian Creek site (ICK 0.2), downstream of outfall 002 near the U.S. Dept. of Energy Kansas City Plant, 1991- 2007.

Fig. 23. Temporal changes in mean total PCB concentrations in green sunfish in the Blue River, upstream (BLK 31.0) and downstream (BLK 27.0) of the confluence of Indian Creek, 1991- 2007.

Fig. 24. Temporal changes in mean total PCB concentrations in green sunfish in the Blue River, downstream of the Indian Creek and Boone Creek confluences, 1991- 2007 .36

Fig. 25. Changes in mean total PCB concentrations in channel catfish at the uppermost Blue River sampling site, upstream of the U.S. Dept. of Energy Kansas City Plant, 1991- 2007. 36

Fig. 26. Changes in mean total PCB concentrations in channel catfish in the Blue River downstream of the confluence with Indian Creek, 1991- 2007.

Fig. 27. Changes in mean total PCB concentrations in channel catfish in the Blue River downstream of the confluences with Indian Creek and Boone Creek, 1991- 2007.

Fig. 28. Changes in mean total PCB concentrations in sunfish in Boone Creek at a site downstream of the U.S. Dept. of Energy Kansas City Plant, 1991- 2007.

Fig. 29. Mean sum of 12 dioxin-like congeners for sunfish and catfish in 2005 and 2007 at seven sites (see also Table 3).

Fig. 30. Mean concentrations (ng/kg) of dioxin toxic equivalents (TEQs) in green sunfish, 2007. .42 


\section{LIST OF FIGURES (cont'd)}

Fig. 31. Mean concentrations ( $\mathrm{ng} / \mathrm{kg}$ ) of dioxin toxic equivalents (TEQs) in channel catfish, 2007..... 43

Fig. B-1. Ratio of original to duplicate result for 20 PCB congeners for 10 pairs of duplicate fish samples. 



\section{LIST OF TABLES}

Table 1. Mean Aroclor-specific PCB concentrations $(\mu \mathrm{g} / \mathrm{g}, \pm \mathrm{SE})$ in green sunfish (Lepomis cyanellus) in streams near the Kansas City Plant, June 2007.

Table 2. Mean Aroclor-specific PCB concentrations $(\mu \mathrm{g} / \mathrm{g}, \pm \mathrm{SE})$ in channel catfish (Ictalurus

punctatus) in streams near the Kansas City Plant, June 2007 14

Table 3. Average concentrations (ng/g) of the most toxic PCBs for catfish and sunfish at each $\mathrm{KCP}$ site..

Table 4. Aroclor-specific PCB concentrations (ng/g wet wt) analyzed from semipermeable membrane devices (SPMDS) deployed near the Kansas City Plant for one month in 2007 and for one month in 2008 .

Table 5. Comparison of observed and expected toxicity of PCB mixtures in fish from sites near

KCP (reference sites excluded)

Table A-1. 2007 Kansas City Plant fish collections.

Table A-2. Field data, Aroclor-specific PCB concentrations (ng/g, wet wt), and \% lipid content, in individual green sunfish and channel catfish fillet collected from sites on Indian Creek (ICK), Blue River (BLK), and Boone Creek (BCK) near the Kansas City Plant, June 2007

Table A-3. Congener-specific PCB concentrations (ng/g, wet wt) in individual green sunfish and channel catfish fillets and SPMD collected from sites on Indian Creek (ICK), Blue River (BLK), and Boone Creek (BCK) near the Kansas City Plant, July 2007. 



\section{LIST OF ACRONYMS}

\begin{tabular}{|c|c|}
\hline BCK & Boone Creek kilometer \\
\hline BLK & Blue River kilometer \\
\hline BMAP & Biological Monitoring and Abatement Program \\
\hline DOE & Department of Energy \\
\hline $\mathrm{ECD}$ & Electron Capture Detection \\
\hline EPA & Environmental Protection Agency \\
\hline FDA & U.S. Food and Drug Administration \\
\hline GPD & Gallons per day \\
\hline ICK & Indian Creek kilometer \\
\hline $\mathrm{KCP}$ & Kansas City Plant \\
\hline NPDES & National Pollutant Discharge Elimination System \\
\hline ORNL & Oak Ridge National Laboratory \\
\hline PCB & Polychlorinated biphenyl \\
\hline QA & Quality Assurance \\
\hline QC & Quality Control \\
\hline SPMD & Semi-permeable Membrane Device \\
\hline TCDD & $2,3,7,8$ tetrachlorodibenzodioxin \\
\hline TEF & Toxicity Equivalent Factor \\
\hline TEQ & Toxic Equivalent \\
\hline $\mathrm{TM}$ & Technical Memorandum \\
\hline WHO & World Health Organization \\
\hline
\end{tabular}





\section{ACKNOWLEDGMENTS}

This study was funded by the U.S. Department of Energy Kansas City Plant (KCP) and Honeywell FM\&T. Special thanks are extended to Mike Stites (KCP) for his guidance and support and to Joe Baker $(\mathrm{KCP})$ for assistance with field sampling. We also thank Test America for providing analytical support. 



\section{INTRODUCTION}

This report presents the results of recent and historical studies of polychlorinated biphenyl (PCB) bioaccumulation in waters near the Kansas City Plant (KCP) in Kansas City, Missouri. The focus of this report is on fish sampling and analysis in the summer of 2007, and how the recent PCB results compare to past levels. In addition to the extensive sampling of fish, semi-permeable membrane devices (SPMDs) were deployed at sites in 2007 and again within the Boone Creek watershed in the spring of 2008.

Studies conducted by the Missouri Department of Conservation in the mid-1980s (McGrath 1988a, 1988b) found high levels of polychlorinated biphenyls (PCBs) and chlordane in fish from the Blue River. These results triggered a fish advisory for the river, which has varied some over the last $20+$ years but currently involves limiting consumption of large carp species (>23") and channel catfish (>19") to once per month and once per week respectively (DHSS 2008). There is also a US and state-wide fish advisory for sensitive human populations.

Oak Ridge National Laboratory staff monitored fish PCB concentrations near the KCP from 1991-1993 (Southworth et al. 1992, Ashwood et al. 1993, Ashwood and Peterson 1994), and in 1998 (Ashwood 1998), 2003 (Peterson et al. 2003), and 2005 (Peterson et al. 2006). These studies in support of the Kansas City Plant characterized concentrations of PCBs in fish from not only the Blue River but also Indian Creek and Boone Creek. When compared to upstream sample stations, elevated PCB concentrations in Indian Creek and Blue River fish have consistently been found at locations downstream of the National Pollutant Discharge Elimination System (NPDES) permitted stormwater discharges (including Outfall 001, 002 and 003), which drain sections of the KCP complex. However, past studies concluded that the KCP appeared to be one of multiple sources of PCBs to both Indian Creek and the Blue River.

The major objectives of the present study are to provide PCB concentrations in fish useful in determining the potential human health risks associated with fish in waters near the $\mathrm{KCP}$, to evaluate the relative significance of KCP PCB discharges relative to other inputs on fish levels, and to determine if levels have changed in the years since fish were last analyzed. Because monitoring change over time is an important component of this effort, the fish sampling locations and species collected in 2007 were essentially the same as in previous studies. In general, locations were chosen upstream and downstream of major KCP outfalls to help evaluate the importance of those outfalls as sources of PCBs. Green sunfish (Lepomis cyanellus) and channel catfish (Ictalurus punctatus) were again the primary species collected. SPMD sampling was deemed an important tool for characterizing storm drain sources of PCBs from the facility. These passive monitors were very effective at tracing PCB contamination within the KCP storm drain network (Peterson et al. 2003; 2006), as they reflect exposure specifically at the emplacement site.

The class of compounds known as PCBs is comprised of 209 different compounds or congeners. They all have the same basic double-ring biphenyl structure but differ by the number and location of chlorine atoms attached to the rings. The number and positions of the chlorine atoms determines the geometric configuration of the molecule, which affects its environmental persistence and toxicity. Natural biological processes degrade PCB molecules by either cleaving the molecule entirely into different compounds or by removing chlorine atoms, which results in different congeners. Different Aroclor mixtures are known by four-digit numbers (e.g., 1242, 1248, 1254, 1260) with the higher numbered mixtures being comprised of more highly chlorinated PCB compounds. Similarly, congeners are identified systematically by number from 1 to 209 with the congeners with a single chlorine atom assigned the lowest numbers and the congener with a complete complement of 10 chlorine atoms assigned 
number 209. In addition to the most-commonly used analytical method of determining Aroclor mixtures, congeners were also analyzed in this study to (1) better evaluate the toxicity of the PCBs in the system and (2) evaluate differences among sites including the distribution of PCBs originating from the facility.

All fish and SPMD samples obtained for this assessment were analyzed by both Aroclor-based analyses (SW846 Method 8082) and also by high resolution gas chromatography/mass spectrometry using isotopically labeled internal standards (EPA Method 1668a). This latter analysis can more unequivocally identify and quantify those PCB congeners responsible for virtually all the toxicity and risk associated with these compounds, relative to Aroclor-based analyses. Much of the PCB use at the KCP, particularly in the part of the facility draining to Outfall 002, was of low chlorinated commercial PCB mixtures which contain far lower concentrations of these highly toxic congeners than higher chlorinated PCBs. The 2007 monitoring for both commercial PCB mixtures (Aroclors) and their specific toxic congener constituents provides the most comprehensive picture yet of the role of the KCP on PCB bioaccumulation in Indian Creek and the Blue River. 


\section{METHODS}

\subsection{DESCRIPTION OF STUDY SITE}

The Kansas City Plant (KCP) is a part of the Bannister Federal Complex located in a commercial and residential area $\sim 13$ miles south of downtown Kansas City, Missouri, within the incorporated city limits. The KCP occupies 137 of the 300 acres covered by the complex. The nearby Blue River and its tributaries, Indian Creek and Boone Creek, receive surface water runoff, discharges permitted under the National Pollutant Discharge Elimination System (NPDES), and groundwater from the federal complex (Figure 1).

Although PCBs are no longer used in KCP operations, remnant areas of PCB soil contamination remain beneath the main building which is not accessible for purposes of remediation. PCBs were used at the KCP in manufacturing operations from the early 1960's through the mid-1970's as a heat transfer fluid in plastic injection molding operations. Several PCB releases occurred associated with heat transfer fluid line breaks. Areas of inaccessible PCB soil contamination remain beneath the building. Numerous corrective actions have been completed to address accessible areas of contamination and to prevent the migration of PCBs into the storm sewer system (DOE 2003). In order to comply with a residual chlorine limit in the KCP's NPDES permit, single pass cooling water discharges to KCP storm sewers were removed during 2002 and 2003. Wastewater discharges from Outfall 002 had been shown by both NPDES monitoring and passive PCB monitors (Peterson 2003) to be a relatively continuous low level source of PCBs to Indian Creek. Following the elimination of single pass cooling water, air conditioning condensate was the only non-rain event source of flow to the storm sewer system. This remaining flow in Outfall 002 amounted to approximately five to ten gallons per minute. At this flow PCBs continue to be detected at approximately $0.5 \mu \mathrm{g} / \mathrm{L}$, which is the permitted discharge limit. In March of 2005 the Outfall 002 Reroute System became operational diverting all non-rain event flow in Outfall 002 to the KCP's Groundwater Treatment System. As a result, Outfall 002 now only discharges following precipitation events and these discharges typically do not contain detectable levels of PCBs. Since this action, average daily flow has decreased from 186,000 gallons per day (GPD) in 2002 when 26 inches of annual rainfall was received to 77,729 GPD when 32 inches of annual rainfall was received. The frequency of discharge from Outfall 002 has decreased from $100 \%$ of the time to only discharging in association with a rain event.

Indian Creek and the Blue River also receive runoff from residential and commercial facilities, and discharges from sewage treatment plants upstream from the KCP. In general, the biological communities of lower Indian Creek and the Blue River below its confluence with Indian Creek are negatively impacted by a number of factors, including industrial and sewage treatment discharges, urban-parking lot runoff, intermittent spills, bank erosion and siltation, excessive sedimentation, and stream channelization. Water quality is relatively good in the Blue River above the confluence with Indian Creek, but a large sewage treatment plant on Indian Creek degrades water quality in the lower half of the river (Petchford et al. 1999, Wilkison et al. 2006). Like many urban streams, the system is flashy (i.e., rapidly rising and falling stream flows), and the extreme flow changes can also adversely affect resident aquatic biota.

\subsection{SAMPLE COLLECTION}

Stream sampling locations relative to KCP discharges are shown in Figure 2. Green sunfish and channel catfish were collected from three sites on the Blue River (BLK25, BLK27, and BLK31) and three sites on Indian Creek (ICK0.2, ICK1.0, and ICK3.0) using backpack electrofishers from June 5 - June 7, 2007. 


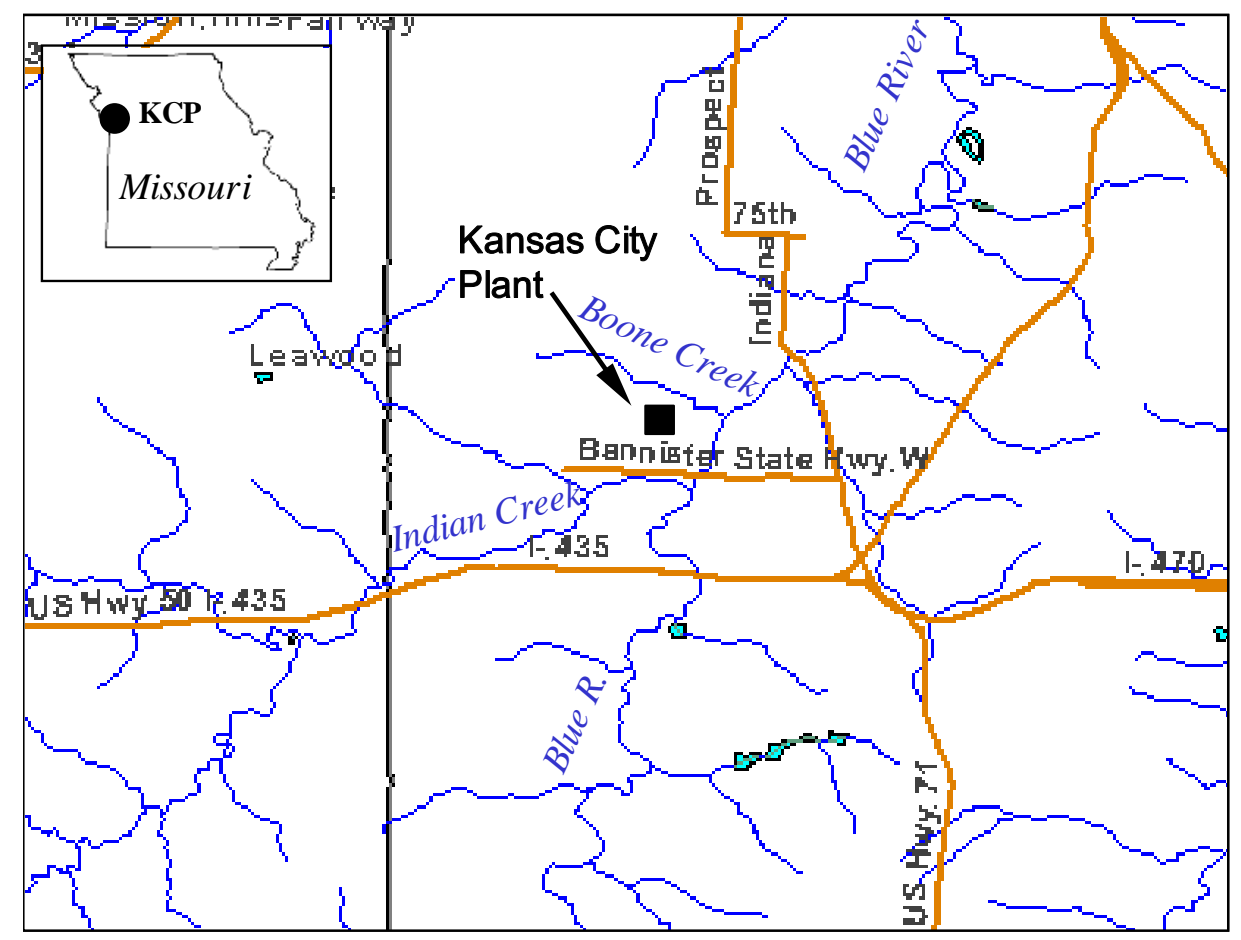

Fig. 1. Location of the Kansas City Plant in relation to local waters and major roads. 


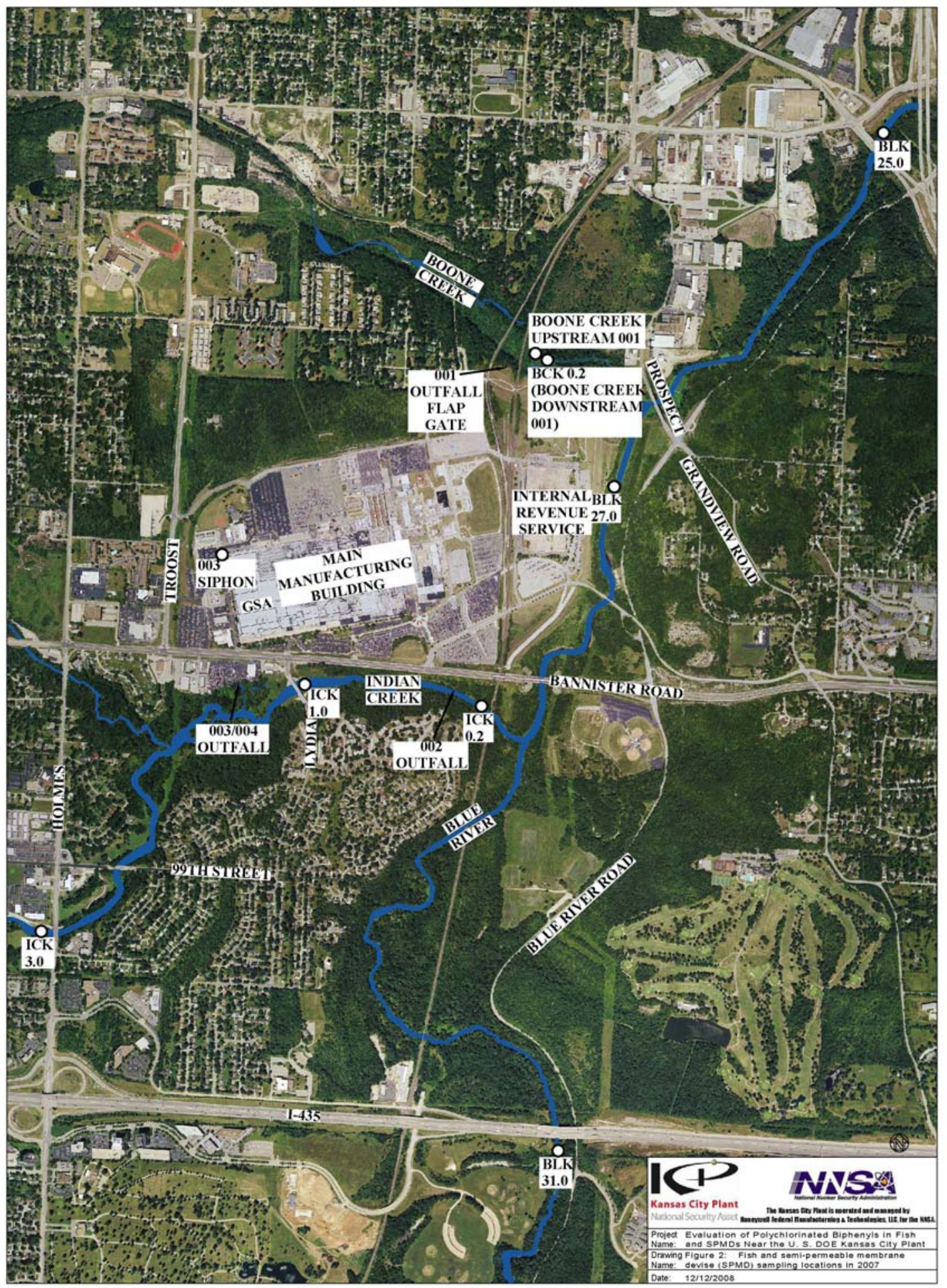

Fig. 2. Fish and semi-permeable membrane device (SPMD) sampling locations near the Kansas City Plant in 2007. 
Additionally, green sunfish were collected from a site on Boone Creek (BCK0.2), a tributary to the Blue River.

Sunfish greater than 40 grams in size and channel catfish greater than 400 grams in size were targeted (Figure 3), in order to minimize possible bias related to size/contaminant covariance and to provide a direct measure of risks to sport fishermen. However, at many sites larger fish were rare and smaller fish were taken to complete efforts to collect eight fish from each sample station. By contrast, when compared to previous sampling efforts, catfish were larger at certain locations during 2007. In addition, prior to the 2007 collection, channel catfish had not been collected during previous sampling efforts at the upper Indian Creek site (ICK3.0). Catfish were abundant here during the June 2007 sampling and represented by wide-ranging size classes. Numerous channel catfish and green sunfish were released at this site during the electrofishing sampling. Due to habitat constraints only small sunfish are typically collected from the Boone Creek sample station. Common snapping turtles (Chelydra serpentina) and unidentified crayfish were noted at the Boone Creek site (BCK0.2).

Semi-permeable membrane devices (SPMDs) were deployed at ten sites (Figure 2) June 5-7, 2007 and retrieved July 13-17, 2007. These sites include ICK0.2, ICK1.0, ICK3.0, BLK25, BLK31, Outfalls 001, 002, 003, and two sites on Boone Creek - one above and one below Outfall 001. SPMDs were also deployed from April 16 to May 16, 2008 at locations throughout Boone Creek, and outfall 001. Boone Creek deployment sites are shown in Figure 4. Trip blanks were not deployed but were analyzed for each field campaign in 2007 and 2008.

\subsection{SAMPLE PROCESSING}

Retained fish were identified by wiring a uniquely numbered tag to the lower jaw (catfish) or through the mouth and operculum (sunfish). Catfish received a stunning blow to the dorso-cranial region and sunfish were wrapped in aluminum foil before being placed on ice in a cooler per ORNL Animal Care and Use Protocol \#0356. Processing of the fish tissue was initiated within 48 hours of collection.

Each fish was weighed, measured to obtain total length, sexed, and examined for any superficial abnormalities. Fish measurement data is presented in Appendix Table A-1. Average catfish lengths and weights per site in Indian Creek and the Blue River ranged from as low as $40 \mathrm{~cm} / 662$ grams at BLK 31 to as high as $46 \mathrm{~cm} / 1010$ grams at ICK 1.0. Average sunfish lengths and weights ranged from as low as 11 $\mathrm{cm} / 33.4$ grams at BLK 31 to as high as $13 \mathrm{~cm} / 49.2$ grams at ICK 3.0. By necessity, a smaller-sized group of fish was collected from Boone Creek where suitable habitat for sunfish was limited. Because the eleven sunfish from Boone Creek lacked sufficient tissue for individual analysis, these filets were composited into three samples. These fish were also too small to accurately make sex determinations. The tabulated lengths and weights (Table A-1) for these fish are means of a 3-fish composite for the first sample and of 4-fish composites for the other two samples.

Green sunfish were de-scaled prior to excising fillets, while catfish fillets were obtained after removing the skin. Fish fillets were individually foiled wrapped, labeled, frozen and transported on dry ice back to ORNL where they were immediately frozen at $-20^{\circ} \mathrm{C}$. Channel catfish fillets were later homogenized at the ORNL fish processing laboratory by making three passes of the frozen fillets through a \#10 meat grinder. A subsample of the thoroughly homogenized, triple-pass ground catfish tissue was then packaged for submitting to the analytical laboratory. For all other species, un-ground fillets were submitted for analysis. Whenever possible, tissues were archived to provide for the possibility of followup analysis. 

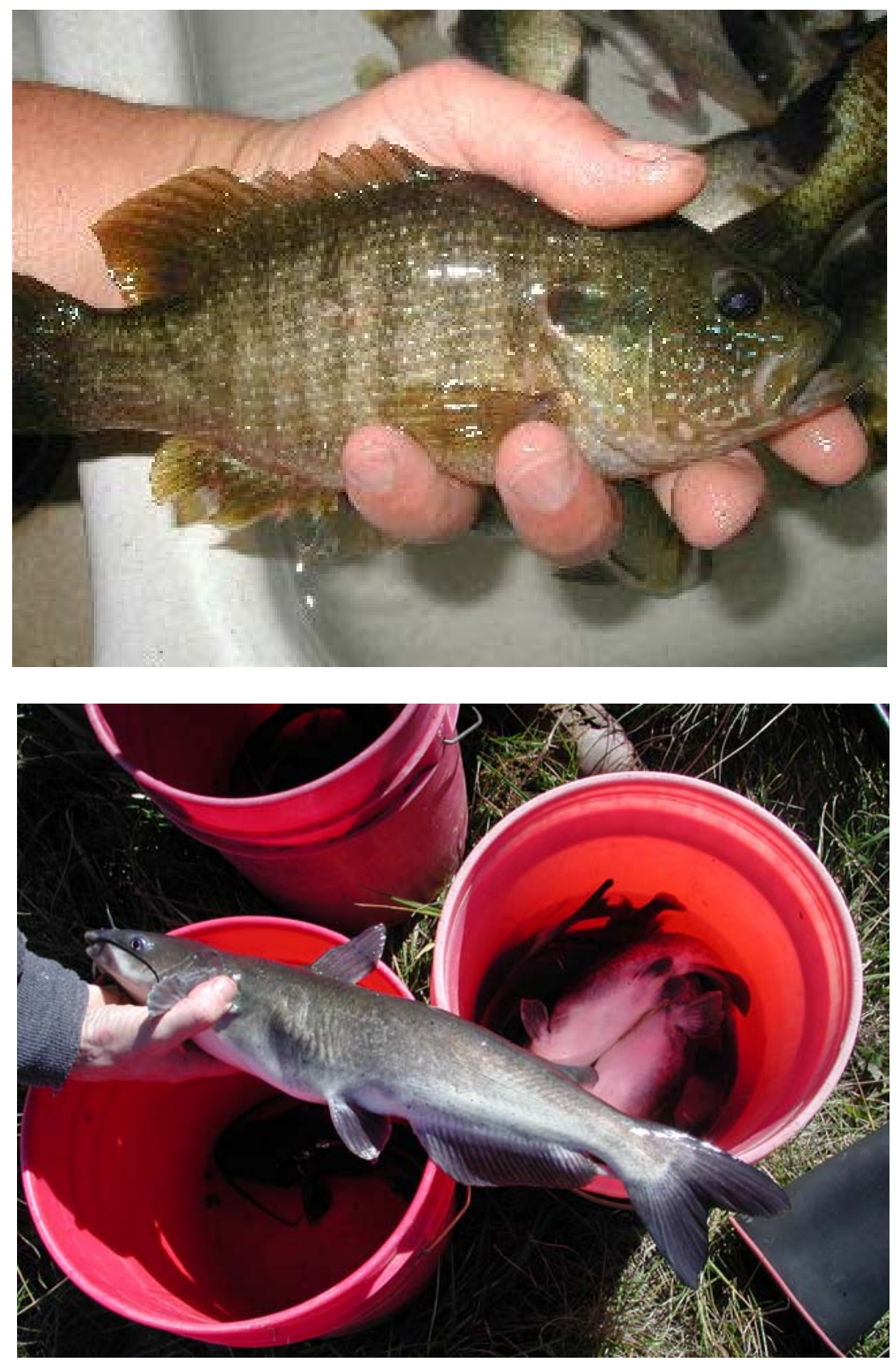

Fig. 3. Targeted fish species collected from stream and river sites near the Kansas City Plant: green sunfish (Lepomis cyanellus; top) and channel catfish (Ictalurus punctatus; bottom). 


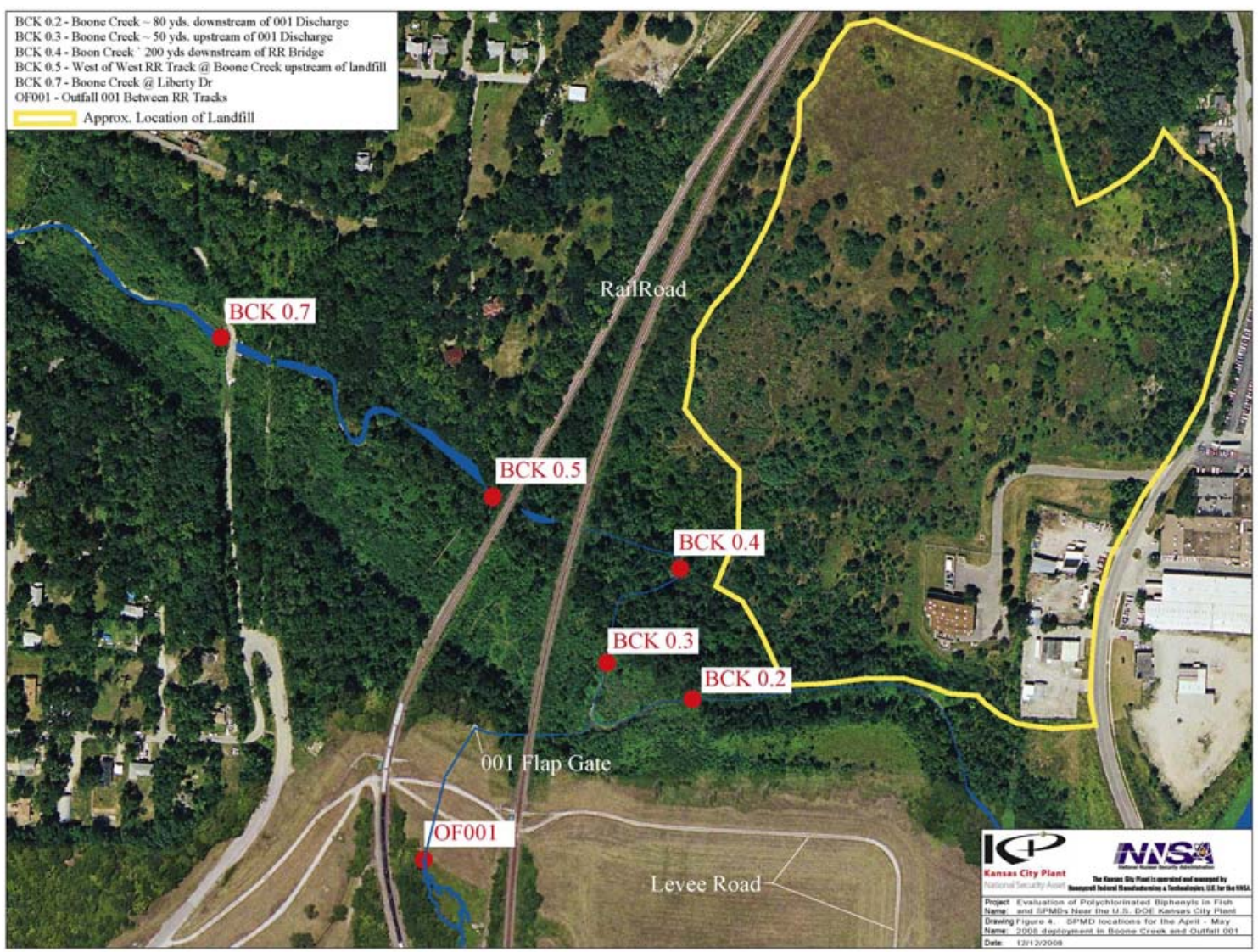

Fig. 4. SPMD locations for the April-May 2008 deployment in Boone Creek and outfall 001. 
Semipermeable membrane devices were prepared using low-density polyethylene lay-flat tubing (160 $\mathrm{cm}$ long, $2.6 \mathrm{~cm}$ wide, by $0.05 \mathrm{~mm}$ thick) (Figure 5). Tubing was cleaned in hexane for 48 hours prior to construction of the SPMDs. Each tube was heat sealed in the middle. One milliliter of triolein oil (95\% purity, Sigma Aldrich, Inc) was pipetted into each compartment of the tubing and spread into a thin layer coating the entire inside of the tubing, after which the tube was heat-sealed at both ends. After the caged SPMDs were placed at the sampling locations for four weeks, the cages were removed and the SPMDs were then extracted from each cage and wiped with a moistened towel to remove surface film. The SPMDs were shipped, on dry ice, to ORNL shortly after being retrieved by KCP personnel in mid-July 2007 and again in spring 2008. Upon receipt, the samples were frozen at $-20^{\circ} \mathrm{C}$. Later the corner was cut from one compartment of an SPMD, and the triolein oil was carefully squeezed into a pre-cleaned (IChem, Inc) glass vial and sent to the laboratory for analysis.
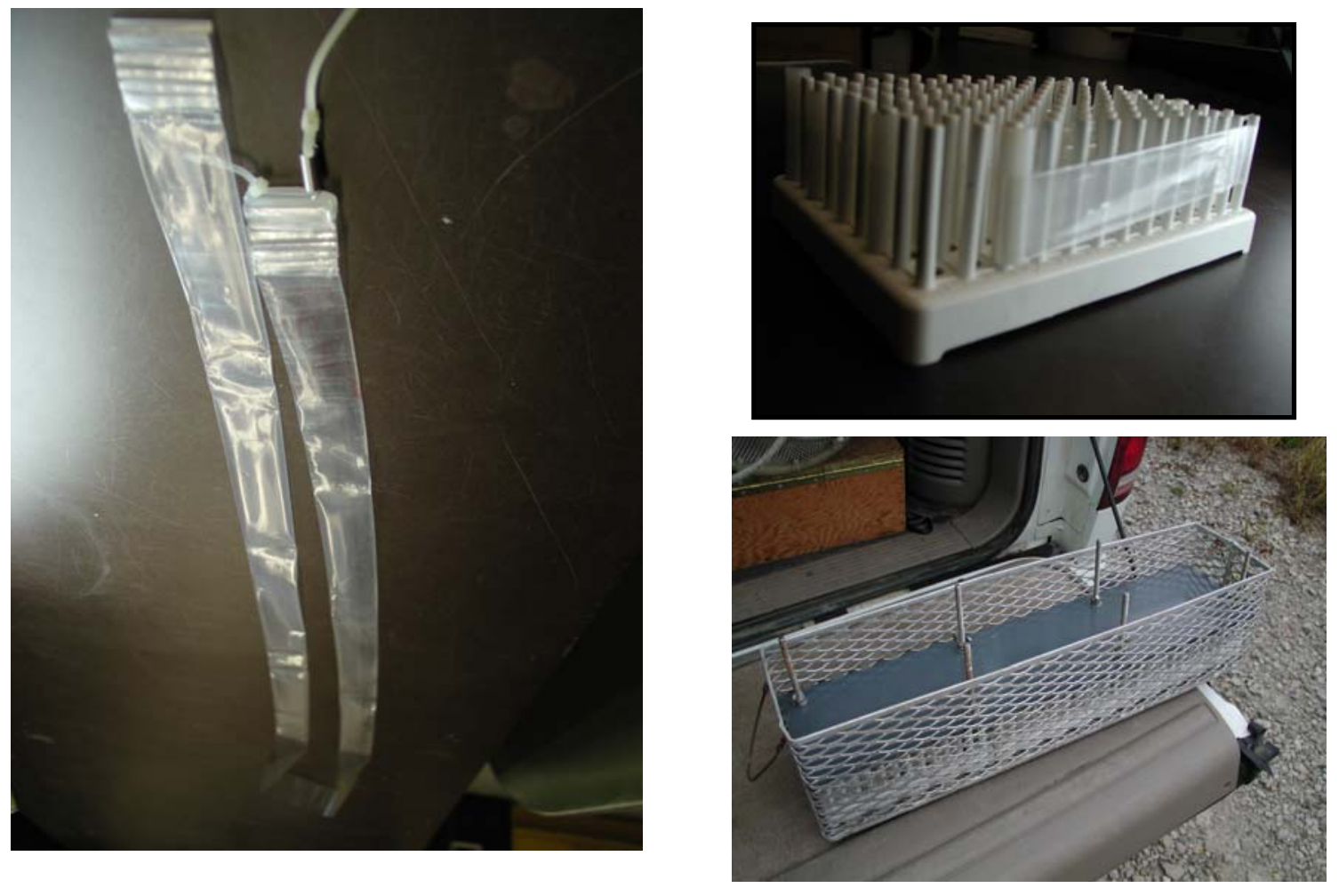

Fig. 5. Semi-permeable membrane devices (SPMDs) are comprised of polyethylene tubes containing a layer of triolein oil (left) and are deployed by wrapping around a test tube rack and caged to help prevent damage from debris or biota during deployment (right, top and bottom). Various cage setups are used depending on whether deployed at a stream or storm drain site.

\subsection{ANALYTICAL METHODS}

Conventional capillary column gas chromatography was used to quantify PCBs (all detected Aroclors). Test America analyzed all samples, including fish and SPMD oils. Samples were prepared by Soxhlet Extraction - SW846 Method 3540B. The extracts were analyzed by SW846 Method 8082 entitled "Polychlorinated Biphenyls (PCBs) by Gas Chromatography" (EPA 1986). The chromatograph was configured using dual capillary columns, with the second column results being considered confirmational 
data. Following dilution in hexane and Florisil cleanup, detection was accomplished using dual electron capture detectors (GC/ECD).

For routine capillary column analyses, results are reported with a variety of qualifiers that can be confusing to people unfamiliar with processing analytical data. Results with qualifiers are presented in a number of the tables in this report. Common value qualifiers presented in this study's datasets include: "<", "iu", and "ap". For any reported value without a qualifier there is reasonable confidence in the quantitation of the reported result. Undetected results that are below the contract required quantitation limit are flagged with a " $<$ ". For each value flagged with a " $<$ ", there is a corresponding lower limit, or method detection limit, that is approximately $10-20 \%$ of the quantitation limit. All detected PCB aroclors were designated Values designated with an "ap" are referencing chromatogram peaks that did not closely align with the fingerprint of Aroclor standards (the chemist identifies PCBs by comparing sample chromatogram peaks with peaks produced by Aroclor standards). The larger the peak, the easier it is to definitively identify a sample as PCB. Most commonly "ap" is used when sample concentrations are near or below the detection limit (and peaks are small).

Considerable effort was made to obtain low detection limits for this study. Important factors that influence the detection limit is sample size, the presence of interferences or other PCB mixtures and instrument limits. Analytical detection limits for this study were deemed excellent given the difficulty in obtaining the optimum sample size for the sunfish samples. Typically, the average quantitation limit was $<0.03 \mu \mathrm{g} / \mathrm{g}$, which translates to a detection limit in the $0.003-0.006 \mu \mathrm{g} / \mathrm{g}$ range.

In order to obtain information on the concentrations of specific highly toxic PCB congeners (WHO 1997), samples were also analyzed by high resolution gas chromatography/high resolution mass spectrometry (HRGC/HRMS), EPA Method 1668a. HRGC/HRMS is several orders of magnitude more sensitive than standard GC/ECD analysis of PCBs as Aroclor mixtures. Detection limits for the 209 PCB congeners normally ranged from 0.1 to $0.2 \mathrm{ng} / \mathrm{g}$ but was occasionally as high as $0.4 \mathrm{ng} / \mathrm{g}$.

\subsection{DATA ANALYSIS}

The first analytical approach used was to assess differences among sites, species, and years by comparing individual Aroclor or congener means for each species-site combination. Some congeners co-elute during gas chromatography analysis and are therefore indistinguishable and reported as a single combined value. In the following analyses, these combinations are usually referred to by the lower numbered member of the group. There are 30 groups of 2 to 6 co-elutes, so treating these co-elute groups as a single congener leaves 167 congener values for data analysis. There are 12 congeners that are generally recognized as being more toxic than the others (numbers 77, 81, 105, 114, 118, 123, 126, 156, 157, 167, 169, and 189). Some of the following analysis therefore deals with just these 12. Since congeners 156 and 157 co-elute, there are really only 11 congener results of significant interest relative to toxicity concerns.

The second analytical approach was a multivariate analysis (principle components analysis, PCA) that uses the results for many congeners simultaneously to detect differences among groups. The value of using PCA for analysis of PCB congeners has been demonstrated for a variety of species (Van den Brink et al. 2003; Papp et al. 2007). For the PCA analysis 20 congeners were used that appeared in every fish sample at detectable levels (\#s 4, 8, 11, 20, 21, 31, 44, 52, 64, 66, 70, 83, 90, 105, 118, 129, 147, 153, $180,187)$. The values were first normalized by dividing the individual congener value by the sum of all congeners for that sample and then log-transformed to achieve or improve normal distribution. 
Lastly, we used the congener data to estimate potential toxicity. Most of the toxicity and carcinogenic risk associated with PCB mixtures arises from a small number of PCB congeners whose chemical structures and toxicological mode of action resemble that of 2,3,7,8 tetrachlorodibenzodioxin, commonly referred to as TCDD or 'dioxin'. TCDD is the most toxic of a class of highly toxic chlorinated organic compounds known as chlorinated dibenzodioxins and chlorinated dibenzofurans. The toxicity of the constituents of this group, as well as the 'dioxin-like' PCBs, has been evaluated by EPA and normalized to TCDD, using a 'Toxicity Equivalent Factor', or TEF. In this scheme, TCDD would have a TEF of 1, and other dioxinlike chemicals factors of 1 or less (Van den Berg et al. 2005). The dioxin-like PCBs generally have TEF's of 0.00003 to 0.0001 , with two congeners (PCB-126 and PCB-169) having higher values (0.1 and 0.03, respectively) (Van Den Berg et al. 2005). Within mixtures such as environmental PCB extracts, the concentration of each of the 12 dioxin-like PCB congeners is multiplied by its TEF to generate a Toxic Equivalent (TEQ). The TEQ's of the mixture's components can then be summed to yield a single value that can be used in risk analyses. Increasingly, EPA has recognized the scientific value and utility of using TEQ-type risk evaluations and acknowledges the pitfalls of Aroclor-based studies that may overestimate the risk (EPA 2008). 



\section{RESULTS}

Mean PCB concentrations ( \pm standard error) are provided in summary tables for fish and SPMDs at each site. Individual fish results are provided in Appendix Table A-2. Depending on the media and the method, results are reported in $\mathrm{ug} / \mathrm{g}$ or $\mathrm{mg} / \mathrm{kg}$ (parts per million), $\mathrm{ng} / \mathrm{g}$ (parts per billion) and $\mathrm{pg} / \mathrm{g}$ (parts per trillion).

For many bioaccumulation studies, mean concentrations are highly dependent upon how detection limit values are used in the calculations. Fortunately for this study, the analytical detection limits were very low, and for the primary Aroclors 1248 and 1254, most sites had no non-detects. The exception was sunfish at the two reference sites, BLK 31 and ICK 3.0, both of which had samples with PCBs below the $0.01 \mathrm{ng} / \mathrm{g}$ detection limit. To calculate the Aroclor-based mean total PCB concentration for each site as shown in tables and figures of this report, the total PCB value for each sample was calculated by averaging just the detected Aroclors. For analysis of congener data, means were calculated in two different ways, first with non-detected values set at 0 and secondly with non-detected values set at half the detection limit. Although using half the detection limit is most common, results by both methods will be discussed.

\subsection{FISH}

Aroclor Analysis - In general, PCB concentrations in sunfish and channel catfish near the KCP were low (Tables 1 and 2), with some samples having PCB concentrations near detection limits, especially in sunfish. The spatial pattern of contamination in fish was very similar to the pattern observed in previous years. Higher PCB concentrations were found in fish downstream of KCP discharges in both Indian Creek and the Blue River with lower levels of PCBs detected in fish collected upstream of the plant. As was the case in all previous monitoring, the highest PCB concentrations in sunfish were found in fish from Boone Creek (average $=0.36 \mathrm{ug} / \mathrm{g}$ ). The highest PCB concentrations in catfish were found from the Blue River (BLK 27.0 and 25.0) and at ICK 0.2, where mean concentrations were at or exceeded 0.40 $\mathrm{ug} / \mathrm{g}$, about four-fold higher than the reference sites (ICK 3.0 and BLK 31.0). PCB concentrations in fish were primarily quantified by Aroclor analysis as Aroclor 1248 and Aroclor 1254. Unlike previous sampling, 1242 was not found in fish, and very few fish had detectable levels of Aroclor 1260. The differences among years in the detection and/or identification in the lower (1242) and higher (1260) Aroclors likely reflects the subjective judgment of the analytical chemist. The chemist must assign a designation to overlapping peaks and/or weathered PCB extracts that have an altered pattern of chromatographic peaks in comparison to standards based on the original commercial mixtures.

Congener Analysis - Concentrations of the total of all 209 congeners, the sum of 12 toxic congeners, and the sum of 'toxic equivalents', or TEQ, for each site-species combination are presented in Table 3 . In general, the total congener values (sum of all 209 congeners) were similar to or slightly less than the Aroclor value for each site-species combination, with the spatial pattern of PCB contamination in the watershed being very similar to the Aroclor results (lower Indian Creek and the Blue River below the confluence, and Boone Creek, were the most contaminated sites). As expected, the quantity of toxic congeners was much smaller than the total congener values, and the TEQ concentrations for each sitespecies combination was even smaller. Low TEQ values were expected since the mixture of Aroclor that was mostly used at KCP (i.e., 1242) contains mostly less-chlorinated congeners and few of the dioxin-like congeners relative to other mixtures (e.g., 1254 and 1260). Unlike the PCB pattern, the TEQ values in sunfish were not very different among sites when using half the detection limit for non-detects (Table 3 ). However, when using 0 for non-detects, there is an apparent difference between those sites above the 
outfalls and those below. When comparing differences for each congener between species at each site, sunfish concentrations were $18 \%$ those for catfish on average (Figure 6). This result is typical of comparisons of fish of different trophic levels. Catfish are more omnivorous than sunfish and are more likely to eat food higher in PCBs such as other fish and detritus.

Table 1. Mean Aroclor-specific PCB concentrations ( $\mu \mathrm{g} / \mathrm{g}, \pm \mathrm{SE}$ ) in green sunfish (Lepomis cyanellus) in streams near the Kansas City Plant, June 2007. $\mathrm{N}=8$ individual fish collected from each site except $\mathrm{N}=3$ fish composite samples in Boone Creek. Detection limit values for all individual samples are reported in Appendix A-1.

\begin{tabular}{lllll}
\hline \multirow{2}{*}{ Site } & \multicolumn{3}{c}{ PCBs } \\
\cline { 2 - 5 } & Aroclor-1248 & Aroclor-1254 & Aroclor-1260 & Total \\
\hline Indian Creek & & & & \\
ICK 3.0 & $<0.01$ & $<0.01$ & $<0.01$ & $0.01 \pm 0.003$ \\
ICK 1.0 & $0.04 \pm 0.02$ & $0.03 \pm 0.01$ & $0 \pm 0$ & $0.07 \pm 0.02$ \\
ICK 0.2 & $0.12 \pm 0.06$ & $0.04 \pm 0.01$ & $0 \pm 0$ & $0.16 \pm 0.08$ \\
Blue River & & & & \\
BLK 31 & $<0.01$ & $<0.01$ & $<0.01$ & $<0.01$ \\
BLK 27.0 & $0.05 \pm 0.01$ & $0.05 \pm 0.01$ & $0.01 \pm 0$ & $0.11 \pm 0.02$ \\
BLK 25.0 & $0.07 \pm 0.01$ & $0.04 \pm 0.01$ & $0 \pm 0$ & $0.12 \pm 0.01$ \\
Boone Creek & & & & \\
BCK 0.2 & $0.21 \pm 0.05$ & $0.15 \pm 0.06$ & $0 \pm 0$ & $0.36 \pm 0.11$ \\
\hline
\end{tabular}

Table 2. Mean Aroclor-specific PCB concentrations ( $\mu \mathrm{g} / \mathrm{g}, \pm \mathrm{SE}$ ) in channel catfish (Ictalurus punctatus) in streams near the Kansas City Plant, June 2007. N=8 individual fish collected from each site except $\mathrm{N}=3$ fish composite samples in Boone Creek. Detection limit values for all individual samples are reported in Appendix A-1.

\begin{tabular}{lllll}
\hline \multirow{2}{*}{ Site } & \multicolumn{3}{c}{ PCBs } \\
\cline { 2 - 5 } & Aroclor-1248 & Aroclor-1254 & Aroclor-1260 & Total \\
\hline Indian Creek & & & & \\
ICK 3.0 & $0.04 \pm 0.01$ & $0.04 \pm 0.01$ & $0.02 \pm 0.01$ & $0.10 \pm 0.02$ \\
ICK 1.0 & $0.10 \pm 0.04$ & $0.09 \pm 0.03$ & $0.04 \pm 0.02$ & $0.23 \pm 0.08$ \\
ICK 0.2 & $0.21 \pm 0.07$ & $0.15 \pm 0.04$ & $0.05 \pm 0.02$ & $0.40 \pm 0.10$ \\
& & & & \\
Blue River & & & & \\
BLK 31 & $0.03 \pm 0.02$ & $0.04 \pm 0.02$ & $0.01 \pm 0.01$ & $0.08 \pm 0.05$ \\
BLK 27.0 & $0.19 \pm 0.04$ & $0.17 \pm 0.02$ & $0.07 \pm 0.01$ & $0.43 \pm 0.07$ \\
BLK 25.0 & $0.20 \pm 0.03$ & $0.16 \pm 0.03$ & $0.05 \pm 0.02$ & $0.41 \pm 0.06$ \\
\hline
\end{tabular}


Table 3. Average concentrations (ng/g) of the most toxic PCBs for catfish and sunfish at each KCP site. The sum of all 209 congeners for each group is included for comparison. The toxic proportion is calculated as the Sum of 12 divided by the Sum of 209.

\begin{tabular}{|c|c|c|c|c|c|c|c|c|c|c|c|c|c|}
\hline Species & $\begin{array}{c}\text { Channel } \\
\text { Catfish }\end{array}$ & $\begin{array}{c}\text { Channel } \\
\text { Catfish }\end{array}$ & $\begin{array}{c}\text { Channel } \\
\text { Catfish }\end{array}$ & $\begin{array}{c}\text { Channel } \\
\text { Catfish }\end{array}$ & $\begin{array}{c}\text { Channel } \\
\text { Catfish }\end{array}$ & $\begin{array}{c}\text { Channel } \\
\text { Catfish }\end{array}$ & $\begin{array}{c}\text { Green } \\
\text { Sunfish }\end{array}$ & $\begin{array}{c}\text { Green } \\
\text { Sunfish }\end{array}$ & $\begin{array}{c}\text { Green } \\
\text { Sunfish }\end{array}$ & $\begin{array}{c}\text { Green } \\
\text { Sunfish }\end{array}$ & $\begin{array}{c}\text { Green } \\
\text { Sunfish }\end{array}$ & $\begin{array}{c}\text { Green } \\
\text { Sunfish }\end{array}$ & $\begin{array}{c}\text { Green } \\
\text { Sunfish }\end{array}$ \\
\hline Site & BLK25 & BLK27 & BLK31 & ICK0.2 & ICK 1.0 & ICK3.0 & BLK25 & BLK27 & BLK31 & ICK0.2 & ICK 1.0 & ICK3.0 & BCK0.2 \\
\hline PCB-77 & 0.086 & 0.090 & 0.051 & 0.088 & 0.047 & 0.044 & 0.176 & 0.125 & 0.040 & 0.230 & 0.067 & 0.047 & 0.387 \\
\hline PCB-81 & 0.053 & 0.040 & 0.040 & 0.062 & 0.049 & 0.042 & 0.048 & 0.047 & 0.050 & 0.055 & 0.045 & 0.050 & 0.050 \\
\hline PCB-105 & 3.107 & 4.000 & 1.030 & 2.554 & 1.335 & 0.724 & 0.503 & 0.367 & 0.062 & 0.566 & 0.179 & 0.073 & 2.467 \\
\hline PCB-114 & 0.258 & 0.319 & 0.075 & 0.262 & 0.134 & 0.055 & 0.036 & 0.037 & 0.042 & 0.064 & 0.037 & 0.036 & 0.180 \\
\hline PCB-118 & 8.011 & 10.513 & 2.671 & 6.011 & 3.686 & 1.897 & 1.089 & 0.851 & 0.145 & 1.195 & 0.426 & 0.191 & 6.333 \\
\hline PCB-123 & 0.193 & 0.246 & 0.063 & 0.175 & 0.097 & 0.036 & 0.026 & 0.021 & 0.035 & 0.040 & 0.026 & 0.046 & 0.079 \\
\hline PCB-126 & 0.150 & 0.109 & 0.051 & 0.087 & 0.073 & 0.027 & 0.039 & 0.034 & 0.050 & 0.050 & 0.042 & 0.050 & 0.046 \\
\hline PCB-156/157 & 0.568 & 0.868 & 0.257 & 0.603 & 0.328 & 0.169 & 0.082 & 0.071 & 0.024 & 0.058 & 0.036 & 0.052 & 0.683 \\
\hline PCB-167 & 0.282 & 0.379 & 0.111 & 0.257 & 0.169 & 0.065 & 0.035 & 0.030 & 0.032 & 0.024 & 0.020 & 0.044 & 0.183 \\
\hline PCB-169 & 0.062 & 0.036 & 0.051 & 0.070 & 0.050 & 0.050 & 0.047 & 0.051 & 0.050 & 0.050 & 0.050 & 0.050 & 0.050 \\
\hline PCB-189 & 0.076 & 0.054 & 0.050 & 0.077 & 0.045 & 0.026 & 0.042 & 0.035 & 0.050 & 0.047 & 0.050 & 0.050 & 0.048 \\
\hline Sum of 12 & 12.85 & 16.65 & 4.45 & 10.25 & 6.01 & 3.13 & 2.12 & 1.67 & 0.58 & 2.38 & 0.98 & 0.69 & 10.51 \\
\hline Sum of 209 & 387.4 & 384.7 & 79.7 & 297.7 & 157.2 & 65.9 & 70.7 & 58.6 & 9.2 & 106.8 & 29.4 & 10.5 & 380.9 \\
\hline Toxic Proportion & 0.033 & 0.043 & 0.056 & 0.034 & 0.038 & 0.048 & 0.030 & 0.029 & 0.063 & 0.022 & 0.033 & 0.066 & 0.028 \\
\hline $\begin{array}{r}\text { Dioxin TEQ }(\mathrm{ng} / \mathrm{g}) \\
\text { w/non-detects }=0.5^{*} \mathrm{DL}\end{array}$ & 0.0170 & 0.0122 & 0.0068 & 0.0114 & 0.0094 & 0.0045 & 0.0054 & 0.0050 & 0.0065 & 0.0065 & 0.0057 & 0.0065 & 0.0064 \\
\hline $\begin{array}{r}\text { Dioxin TEQ }(\mathrm{ng} / \mathrm{g}) \\
\text { w/non-detects }=0\end{array}$ & 0.0147 & 0.0122 & 0.0030 & 0.0096 & 0.0076 & 0.0017 & 0.0015 & 0.0022 & 0.00001 & 0.0007 & 0.0004 & 0.00001 & 0.0016 \\
\hline
\end{tabular}




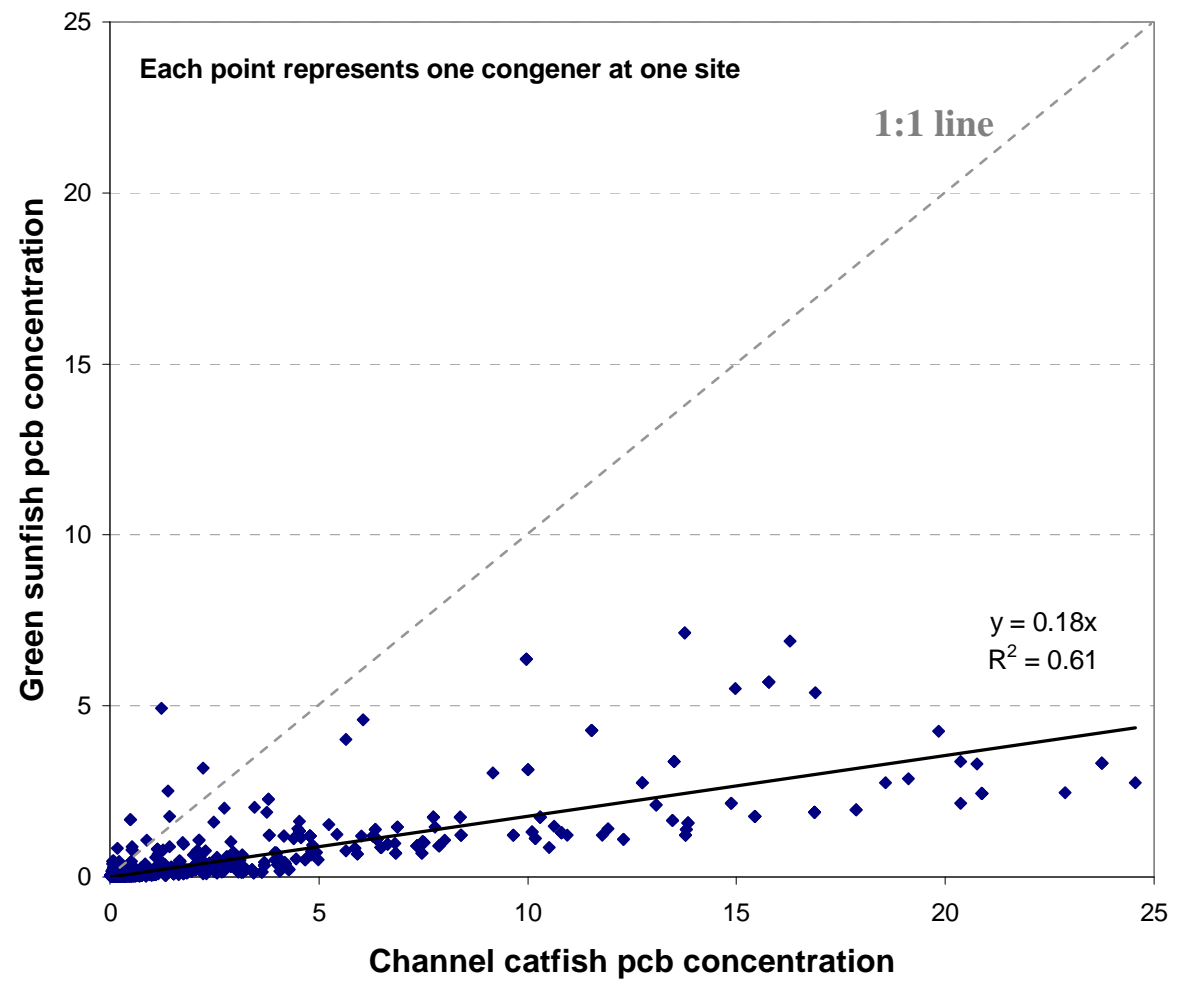

Fig. 6. Plot of PCB congener concentration for each species pair (catfish versus sunfish) for each congener at each of six sites.

\subsection{SEMIPERMEABLE MEMBRANE DEVICES (SPMDs)}

Semipermeable membrane devices have been effectively used to monitor PCBs within the storm drain network at KCP (Peterson et al. 2003), but detection limits and sediment clogging have impaired somewhat their utility as an in-stream monitor. SPMDs are affected by flow, temperature and other factors, and should be considered a gross measure of PCB exposure. The 2007 and 2008 SPMD Aroclor results are presented in Table 4, and congener results presented in Appendix Table A-3. Sampling locations are indicated in Figures 2 and 4.

There are two common features indicated by the results from both years: (1) the higher chlorinated Aroclor (1260) was not detected in any of the samples, and (2) Aroclor 1254 was detected in all samples both years. About half of the samples in 2007 had detects for Aroclor 1248 while all of the 2008 samples had detectible levels of Aroclor 1248. Another feature common to results from both years is that the trip blank was high being 670 and 1100 for Aroclor 1248 and 1254 in 2007, and 410 for Aroclor 1248 and 600 for Aroclor 1254 in 2008. Because of the high blanks, results were calculated minus the blank values in Table 4. In general, the 2007 results were consistent with fish results where locations overlapped: total PCBs were highest in Boone Creek and the Blue River, with the lowest values in upper Indian Creek and the upper Blue River. Outfall 003 was unexpectedly high during the 2007 deployment. In 2008 total PCBs were highest at Boone Creek above and below outfall 001, consistent with 2007 results. Overall PCB congener patterns were similar to the Aroclor data, but appeared to be less discriminatory in separating site differences, especially in 2008. The blank values for the individual congeners were 
Table 4. Aroclor-specific PCB concentrations (ng/g wet wt) analyzed from semipermeable membrane devices (SPMDS) deployed near the Kansas City Plant for one month in 2007 and for one month in 2008

\begin{tabular}{|c|c|c|c|c|c|c|c|c|c|}
\hline$\underline{\text { Site }}$ & Date & Sample No. & Aroclor 1248 & $\begin{array}{l}1248 \text { minus } \\
\text { trip blank }\end{array}$ & $\underline{\text { Aroclor } 1254}$ & $\begin{array}{l}1254 \text { minus } \\
\underline{\text { trip blank }}\end{array}$ & $\underline{\text { Aroclor } 1260}$ & $\underline{\text { Total PCBs }}$ & $\begin{array}{l}\text { Total PCBs } \\
\text { minus blanks } \\
\end{array}$ \\
\hline BLK 25 & $7 / 13 / 07$ & 12769 & 1800 & 1130 & 830 & 0 & $<360 \mathrm{iu}$ & 2630 & 1130 \\
\hline BLK 31 & $7 / 13 / 07$ & 12738 & $<550 \mathrm{iu}$ & 0 & 1400 & 300 & $<550 \mathrm{iu}$ & 1400 & 300 \\
\hline ICK 0.2 & $7 / 13 / 07$ & 12737 & 810 & 140 & 880 & 0 & $<390 \mathrm{iu}$ & 1690 & 140 \\
\hline ICK 1.0 & $7 / 13 / 07$ & 12768 & $<520 \mathrm{gu}$ & 0 & 510 & 0 & $<510 \mathrm{iu}$ & 510 & 0 \\
\hline ICK 3.0 & $7 / 13 / 07$ & 12937 & 320 & 0 & 1000 & 0 & $<390 \mathrm{iu}$ & 1320 & 0 \\
\hline BCK above & $7 / 13 / 07$ & 12587 & 4200 & 3530 & 1900 & 800 & $<1500 \mathrm{iu}$ & 6100 & 4330 \\
\hline BCK below & $7 / 16 / 07$ & 12739 & 2300 & 1630 & 1200 & 100 & $<980 \mathrm{iu}$ & 3500 & 1730 \\
\hline OF001 & $7 / 13 / 07$ & 12938A & $<4500 \mathrm{gu}$ & 0 & 1800 & 700 & $<1500 \mathrm{iu}$ & 1800 & 700 \\
\hline OF001 & $7 / 13 / 07$ & 12938B & $<4100 \mathrm{gu}$ & 0 & 1900 & 800 & $<1300 \mathrm{iu}$ & 1900 & 800 \\
\hline OF002 & $7 / 13 / 07$ & 12939 & $<5100$ & 0 & 1900 & 800 & $<980 \mathrm{iu}$ & 1900 & 800 \\
\hline OF003 & $7 / 13 / 07$ & $12589 \mathrm{~A}$ & $<540 \mathrm{iu}$ & 0 & 2900 & 1800 & $<730 \mathrm{gu}$ & 2900 & 1800 \\
\hline OF003 & 7/13/07 & 12589B & $<610 \mathrm{gu}$ & 0 & 3200 & 2100 & $<800 \mathrm{gu}$ & 3200 & 2100 \\
\hline Trip blank & $7 / 13 / 07$ & 12767 & 670 & & 1100 & & $<320 \mathrm{gu}$ & & \\
\hline BCK 0.2 & $5 / 16 / 08$ & 13611 & 2100 & 1690 & 540 & 0 & $<300 \mathrm{iu}$ & 2640 & 1690 \\
\hline outfall 001 & $5 / 16 / 08$ & 13614 & 1000 & 590 & 270 & 0 & $<460 \mathrm{iu}$ & 1270 & 590 \\
\hline BCK 0.3 & $5 / 16 / 08$ & 13616 & 2000 & 1590 & 790 & 190 & $<620 \mathrm{iu}$ & 2790 & 1780 \\
\hline BCK 0.4 & $5 / 16 / 08$ & 13612 & 790 & 380 & 260 & 0 & $<220 \mathrm{iu}$ & 1050 & 380 \\
\hline BCK 0.5 & $5 / 16 / 08$ & 13610 & 1300 & 890 & 360 & 0 & $<410 \mathrm{iu}$ & 1660 & 890 \\
\hline BCK 0.7 & $5 / 16 / 08$ & 13615 & 1600 & 1190 & 380 & 0 & $<470 \mathrm{iu}$ & 1980 & 1190 \\
\hline ICK 0.2 (dup) & 7/13/07 & 12737 & 620 & 210 & 600 & 0 & $<320 \mathrm{iu}$ & 1220 & 210 \\
\hline ICK 1.0 (dup) & $7 / 13 / 07$ & 12768 & 570 & 160 & 570 & 0 & $<230 \mathrm{iu}$ & 1140 & 160 \\
\hline Trip blank & $5 / 16 / 08$ & 13613 & 410 & & 600 & & $<260 \mathrm{iu}$ & & \\
\hline
\end{tabular}

(dup) re-analysis from 2007

gu- elevated reporting limit. Reporting limit is elevated due to matrix

interference

iu-matrix interference 
unusually high in 2008; subtraction of the blank values from the deployed SPMDs resulted in negative values for nearly half the samples. The reason for the high congener values in the blank in both sampling years is unknown, but SPMD oils are very sensitive to PCB exposure and can take up PCBs from the air. When interpreting the SPMD results, there is greater confidence in the sampling site results where PCBs are substantially higher than the blank concentrations. 


\section{DISCUSSION}

The PCB results in fish and SPMDs are evaluated in the following discussion by (1) evaluating the spatial patterns of bioaccumulation, (2) evaluating the role of the KCP using principal components analysis, (3) evaluating PCB trends over time, and (4) by putting the current results in perspective (relative to other waters and risk benchmarks).

\subsection{SPATIAL PATTERNS OF CONTAMINATION}

Biological sampling sites were chosen to bracket the major discharges from KCP to Indian Creek and the Blue River. Although total PCB concentrations in sunfish were relatively low at all sites, an association with the KCP and its discharges at the sites downstream of the KCP was again evident in 2007, as it had been in previous monitoring (Aroclor results are shown in Figures 7 and 8). Mean PCB concentration in Indian Creek sunfish was highest at ICK $0.2(0.16 \mathrm{ug} / \mathrm{g})$ and declined slightly at downstream sites in the Blue River (Table 1). Lowest concentrations were found at the upstream reference sites at BLK $31(<0.01$ $\mathrm{ug} / \mathrm{g}$ ) and ICK $3.0(0.01 \mathrm{ug} / \mathrm{g})$. A similar pattern was evident for PCBs in channel catfish (Table 2 and Figures 7 and 9). For catfish, PCB levels were also lowest at the two upstream reference sites and highest at the lower Indian Creek site, ICK $0.2(0.40 \mathrm{ug} / \mathrm{g})$, and at the two downstream Blue River sites, BLK 27 $(0.43 \mathrm{ug} / \mathrm{g})$ and BLK $25(0.41 \mathrm{ug} / \mathrm{g})$.

PCB levels in sunfish and catfish were high in 2007 relative to 2005 and 2002 at sites downstream of $\mathrm{KCP}$ discharges to Indian Creek and the Blue River. In the case of sunfish, PCB levels in all years are very low, so the absolute increase is small. In the case of catfish, it is likely that the larger size of fish, and the resultant higher level of lipids, is at least in part responsible for the higher values in 2007. For example, the average weight of catfish at ICK 0.2 was 514 grams in 2005 (with $2.4 \%$ lipids) and 808 grams (with 3.9\% lipids) in 2007. Since PCBs are known to be lipophilic, the higher lipid content of fish in 2007 could explain the concomitant higher levels of PCBs in 2007. Similar sized fish are targeted across years to avoid correlation issues with size; however, in most years there is little choice but to take what specimens are available.

In 2007, the distinction between lower chlorinated mixtures (Aroclor 1242/1248) and highly chlorinated mixtures (Aroclor 1254/1260) was less clear, with both occurring at all sites (Tables 1-2). Aroclor 1242 was not detected in any samples. Distinguishing Aroclor differences is undoubtedly more difficult when PCB levels are near the detection limit, as was the case for many of the collected KCP samples, particular the sunfish samples (See Appendix Table A-2). In addition, as discussed earlier there is some subjectivity among chemists in distinguishing and quantifying Aroclor mixtures during chemical analysis.

The Aroclor-based SPMD results do provide indication of the presence of PCBs in storm drain and surface waters within or near the KCP. In the 2007 deployment, SPMDs place in outfall 003 and two Boone Creek sites upstream and downstream of 001 accumulated the highest PCB levels, with more moderate levels found in SPMDs placed in 001, 002, and the lower Blue River (BLK 25.0). PCB concentrations in SPMDs placed at other creek and river locations, including upstream reference sites, were either not detected or low enough after subtracting the blank to question whether PCBs were detected from the sampling site. The 2008 SPMD deployment appears to confirm the 2007 results that there are PCBs in Boone Creek waters both upstream and downstream of 001. It's important to note that flow has not been considered in this evaluation, but varied considerably between sites. An assessment of flux may reveal a very different pattern than the relative concentrations. SPMDs are largely qualitative tools and are most valuable in providing gross differences in PCB exposure. 

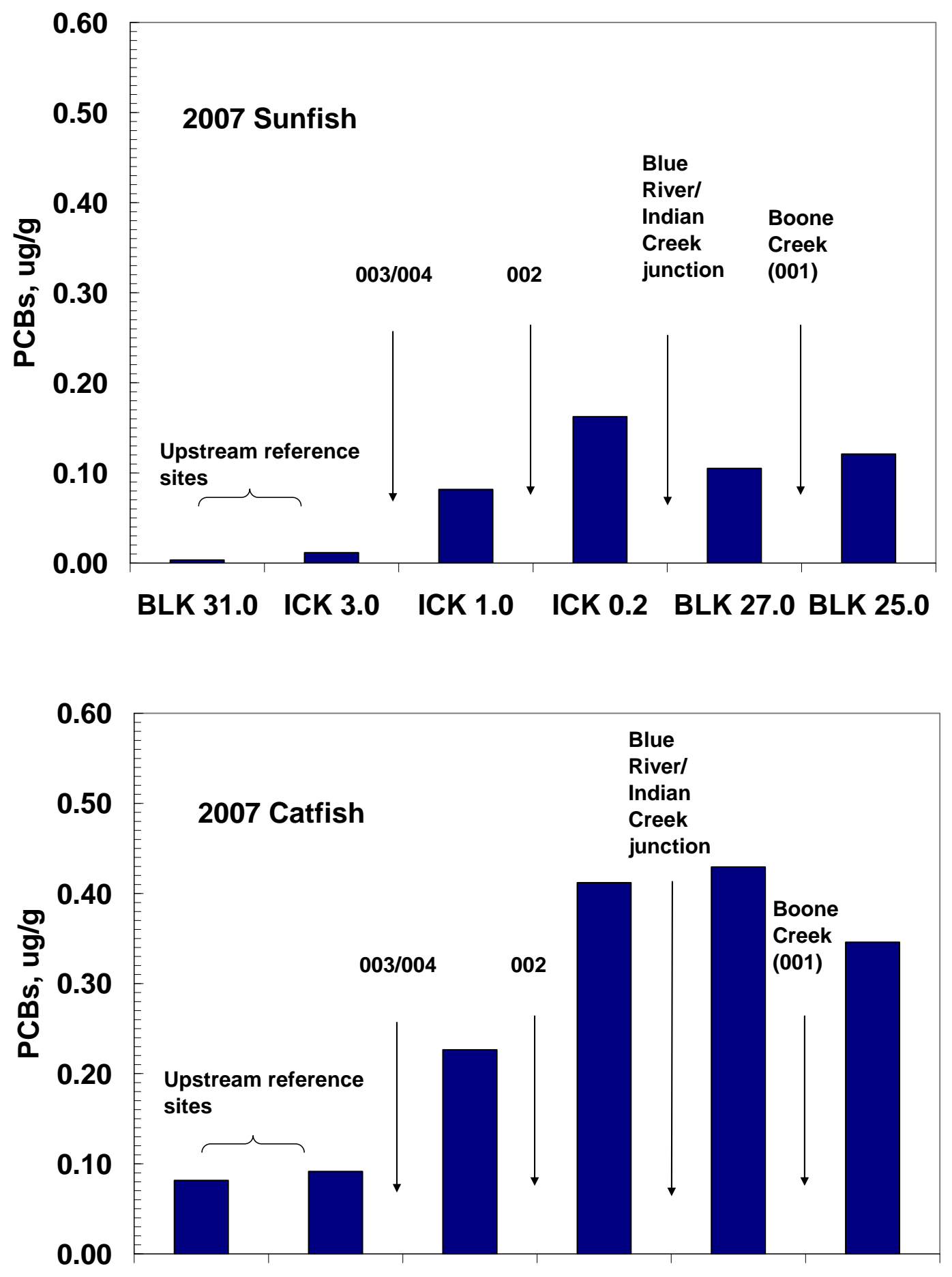

BLK 31.0 ICK 3.0 ICK 1.0 ICK 0.2 $\quad$ BLK 27.0 BLK 25.0

Fig. 7. Spatial pattern of mean PCB (Aroclor 1248/1254/1260) concentrations (ug/g) in green sunfish (top graph) and channel catfish (bottom graph), Indian Creek and the Blue River, 2007. 


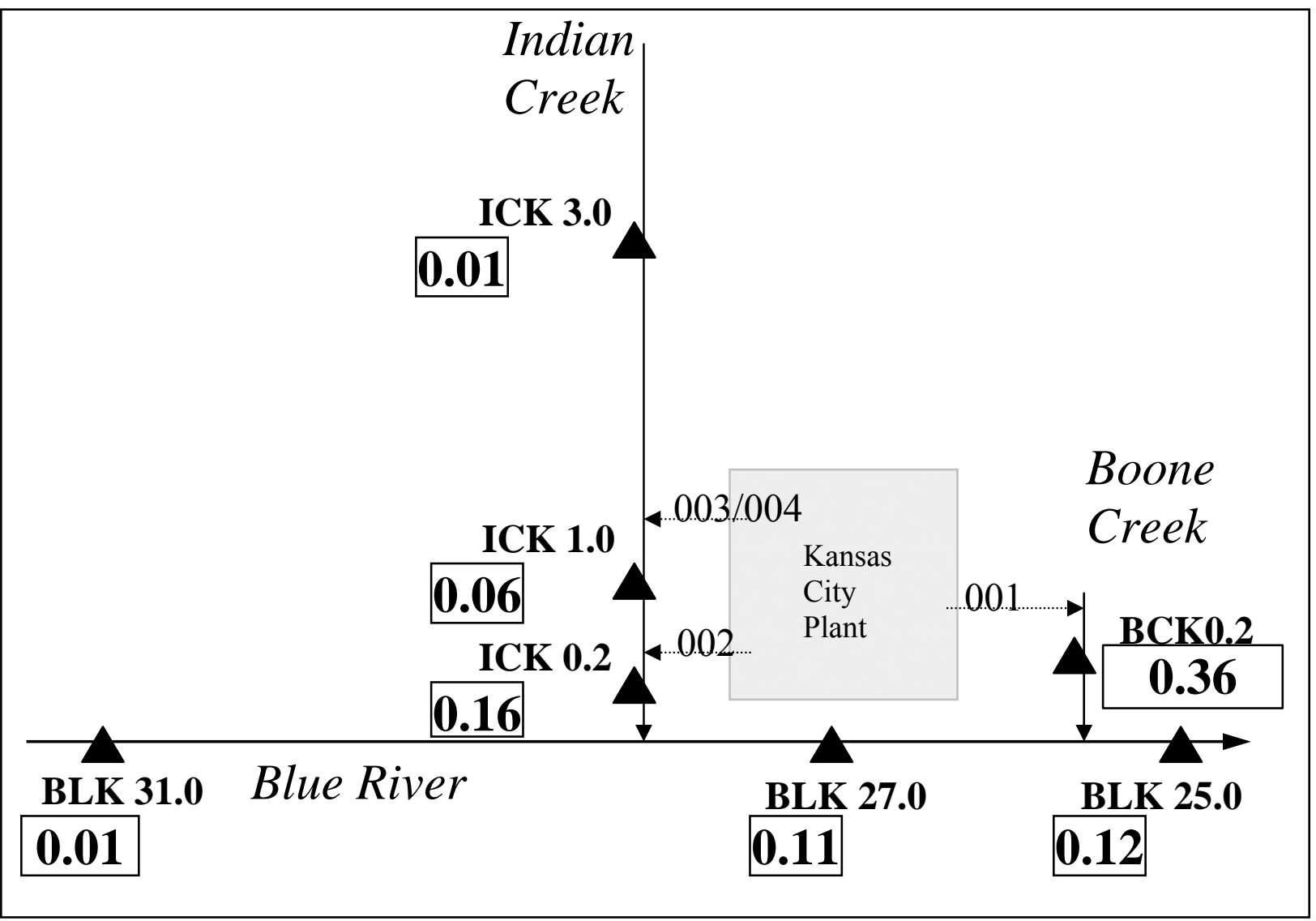

Fig. 8. Mean concentrations ( $\mu \mathrm{g} / \mathrm{g})$ of PCBs (Aroclor 1248,1254, and 1260) in green sunfish, June 2007. 


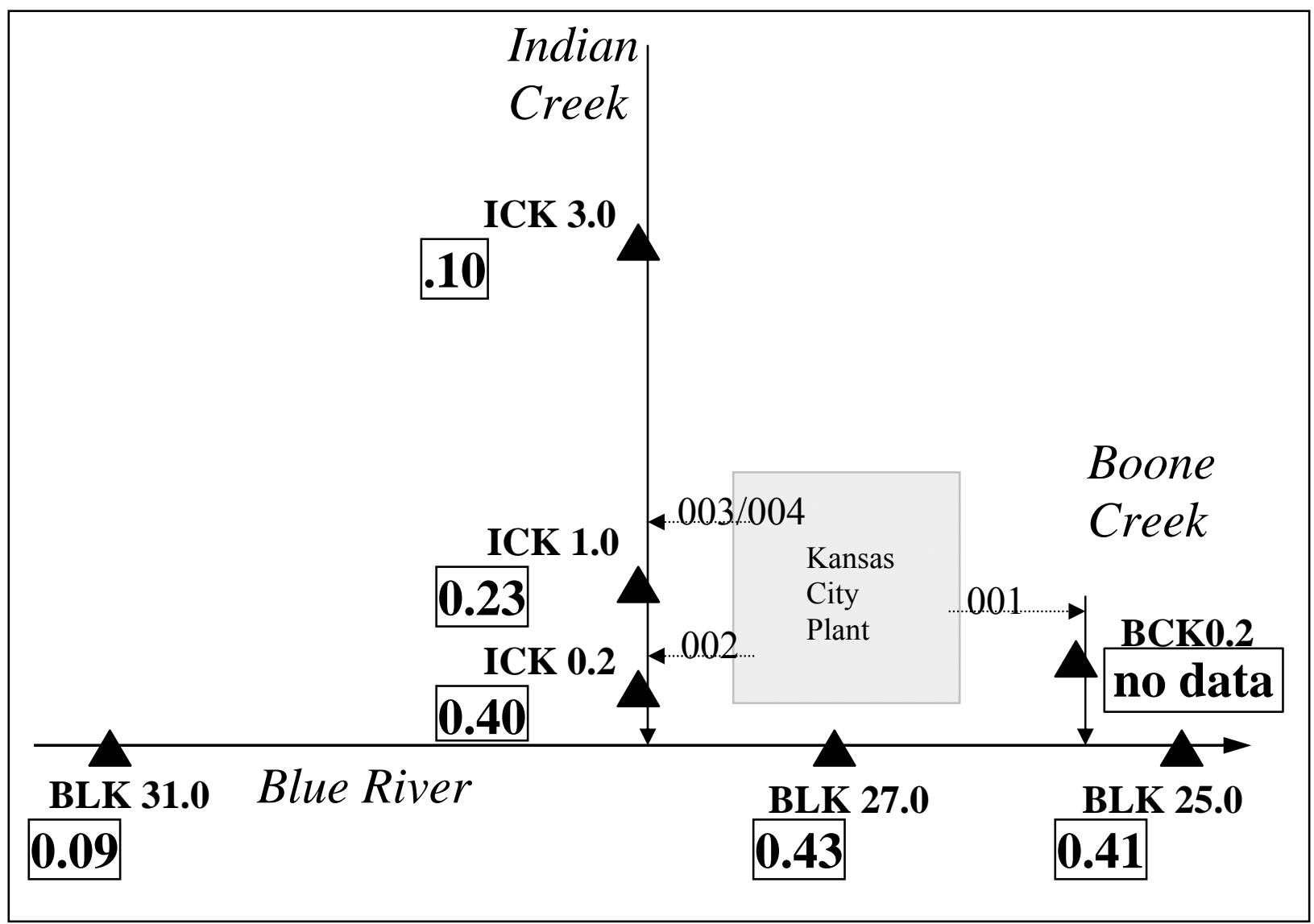

Fig. 9. Mean concentrations ( $\mu \mathrm{g} / \mathrm{g})$ of PCBs (Aroclor 1248, 1254, 1260) in channel catfish, June 2007. 


\subsection{ROLE OF THE KANSAS CITY PLANT}

The mean congener concentrations were compared among select pairs of sites to determine which congeners are most likely contributed by the facility. Figure 10 shows the difference in concentration of each congener between the most upstream (reference) Blue River site (BLK 31) and the most downstream Blue River site (BLK 25). There are many congeners that show up at a relatively higher concentration at the site downstream of the facility. Importantly most of those congeners were not the most toxic congeners. Congeners with higher concentrations in catfish also usually had elevated concentrations in sunfish as well, though usually not as high as catfish. Figure 11 shows a similar comparison for the most upstream Indian Creek site (ICK 3.0) and the most downstream Indian Creek site (ICK 0.2). The results were similar to those for the Blue River sites with most of the same congeners showing up in greater concentrations downstream of the facility.

The last pair-wise comparison was between Indian Creek sites ICK 1.0 and ICK 0.2 to see if differences could be detected that might be interpreted as differences in makeup of PCBs being released from outfalls 002 and 003 (Figure 12). There are several congeners with concentrations higher below outfall 002 than below outfall 003, which suggests that more PCBs may be coming from the 002 outfall. For all three comparisons the differences are greater for the lower numbered (i.e., lower chlorinated) congeners.

The principle components analysis revealed a pronounced difference among species along the first principle component axis (Figure 13) when data from all sites were combined. This suggests that there are probably several congeners that occur disproportionately between the two species. Because of the apparent differences among the two species, the principle components analysis was performed on the two species separately to further pursue possible differences among sites. Figure 14 shows the plot of the first two principle component scores for 52 sunfish from 6 sites. The two upstream reference sites (BLK 31 and ICK 3.0) are largely distinct from the other four sites. Also of note is how little variation there is among the samples from BLK 25 (black circles in Figure 14).

Figure 15 shows results from the same principle components analysis for catfish at the six sites. For catfish the BLK 25 and BLK 27 sites are largely distinct from the other sites based on the first two principle component scores, while the other four sites are largely indistinguishable from each other.

A principle components analysis of the 12 species-site groups revealed no obvious trends and is not shown here. However, a plot of just the three Blue River sites for the two species reveals a clear difference between the two species and between the reference and impacted sites (Figure 16). A similar plot for the three sites in Indian Creek does not show clear demarcation among sites or species though there is some separation between species (Figure 17).

Principle components analysis was applied to the 2007 SPMD data using 40 congeners that were detected in all 10 SPMD samples. A plot of the first two components reveals little about patterns or similarities among sites (Figure 18). A plot of the second and third components (Figure 19) seems to separate upstream sites, outfall sites, and downstream sites into separate groupings, although this interpretation is somewhat subjective.

In summary, the principal components analysis confirms differences among sites and species similar to the total PCB comparisons (e.g., upstream vs below KCP sites), but provides additional evidence of a different congener makeup in fish above and below KCP discharges, and thus different PCB exposure, between sites. KCP is clearly an additional source of PCBs to downstream fish, but appears to contribute only a modest level of additional risk associated with eating those fish, based on the congener pattern. 

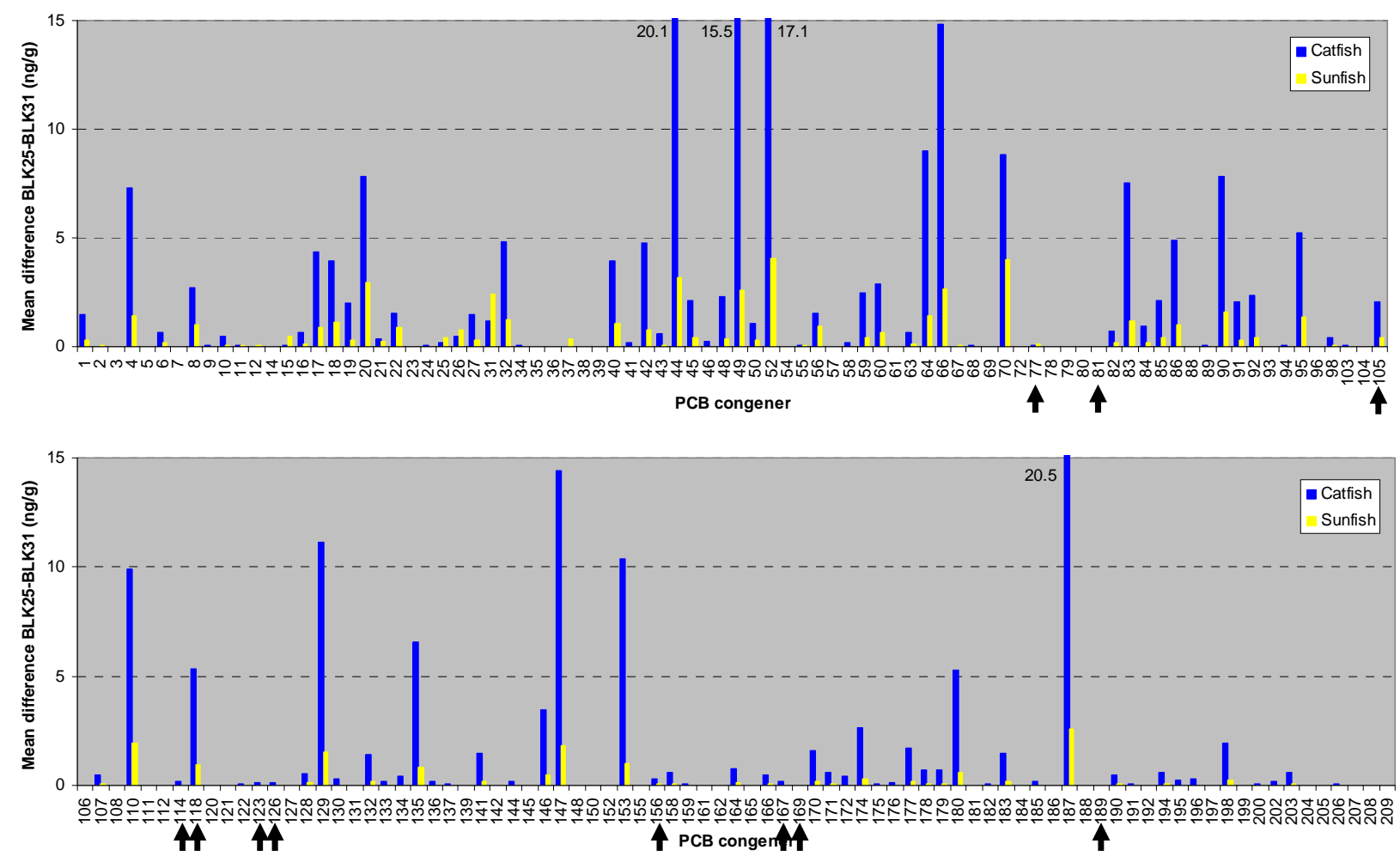

Fig. 10. Difference in PCB congener concentrations in catfish (blue) and sunfish (yellow) between BLK 26 and BLK 31. Congener \#s 1-105 in top panel and \#s 106-209 in lower panel. Arrows identify 12 most toxic congeners. 

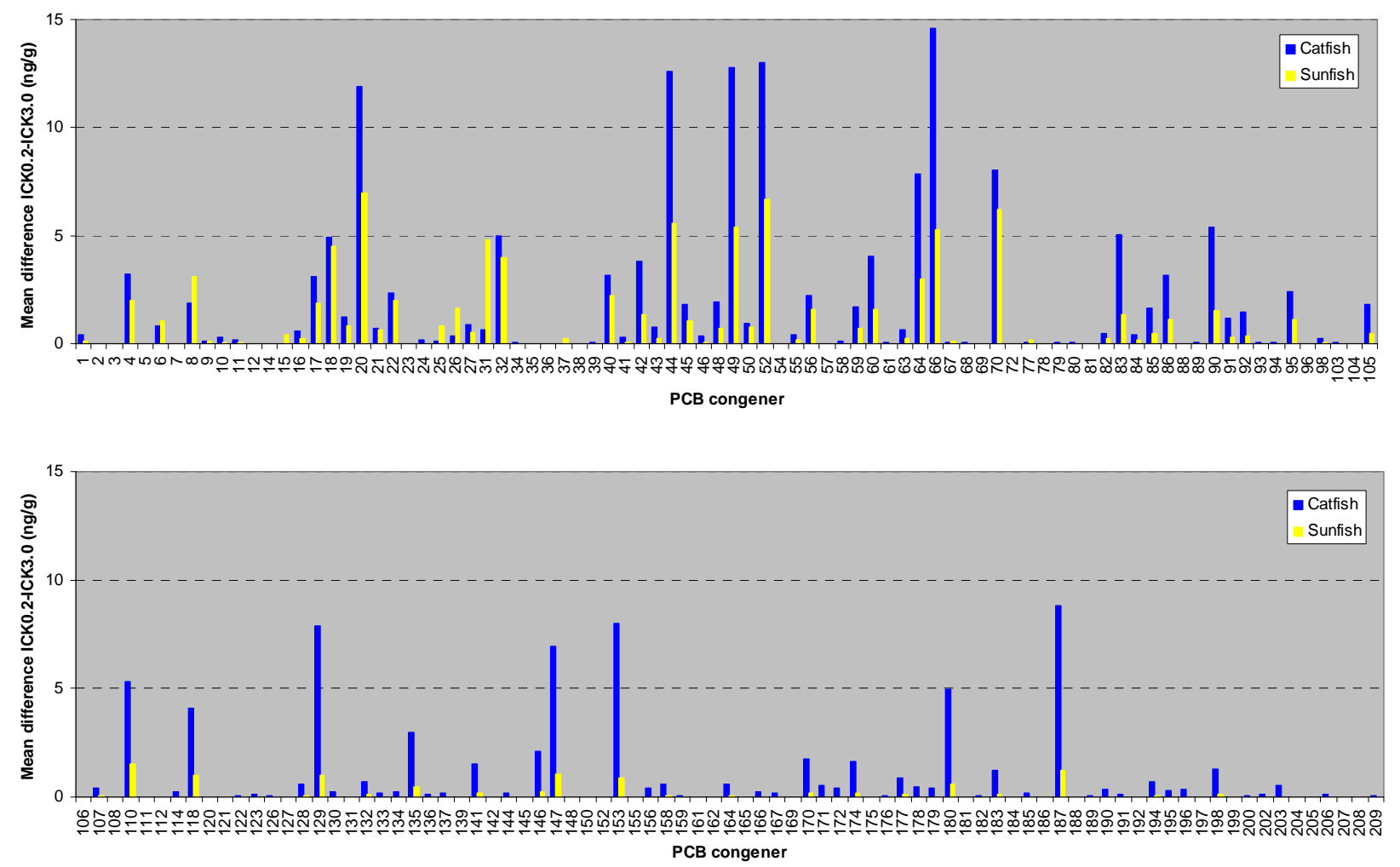

Fig. 11. Difference in PCB congener concentrations in catfish (blue) and sunfish (yellow) between ICK 0.2 and ICK 3.0. Congener \#s 1-105 in top panel and \#s 106-209 in lower panel. 

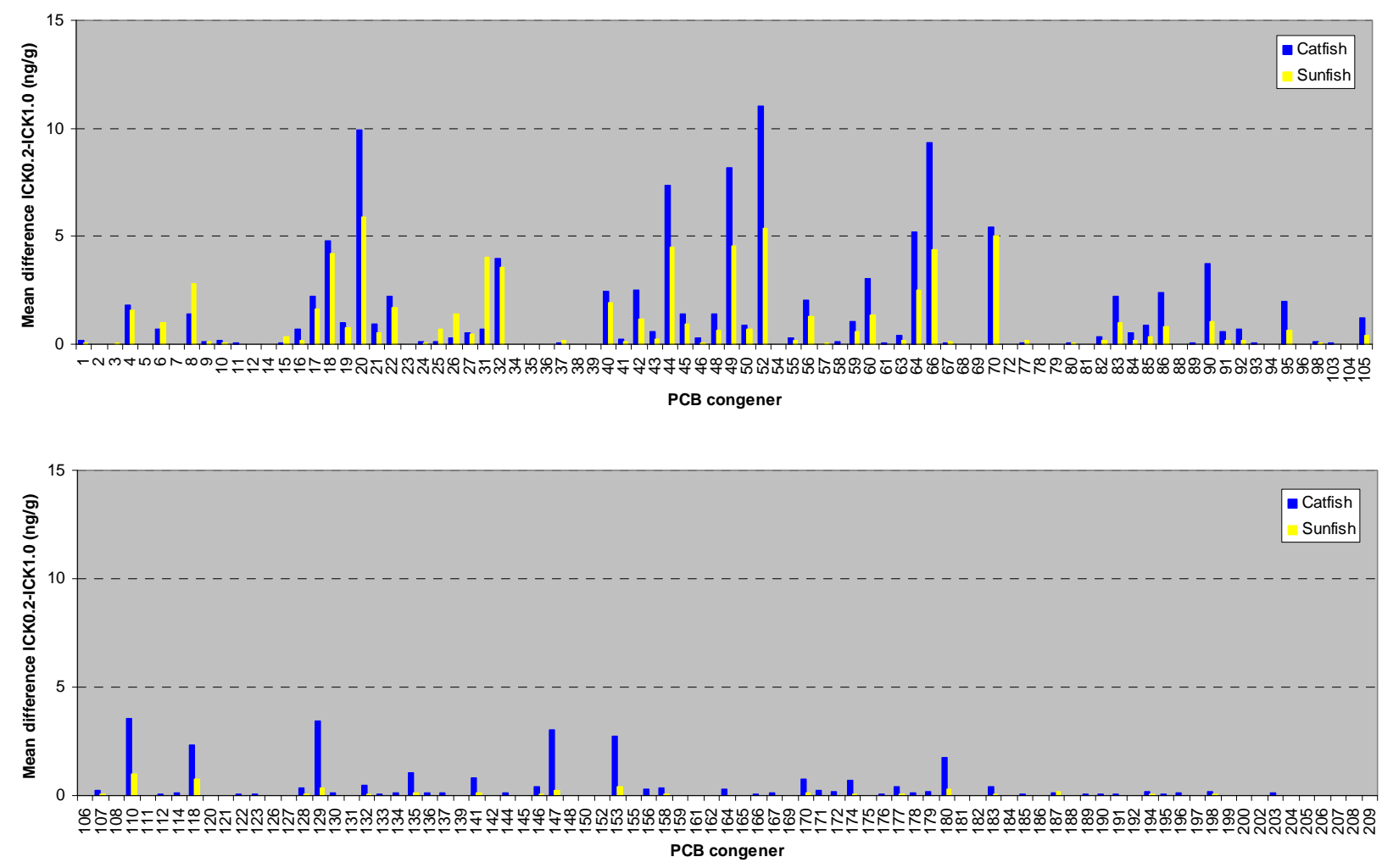

Fig. 12. Difference in PCB congener concentrations in catfish (blue) and sunfish (yellow) between ICK 0.2 and ICK 1.0. Congener \#s 1-105 in top panel and \#s 106-209 in lower panel. 


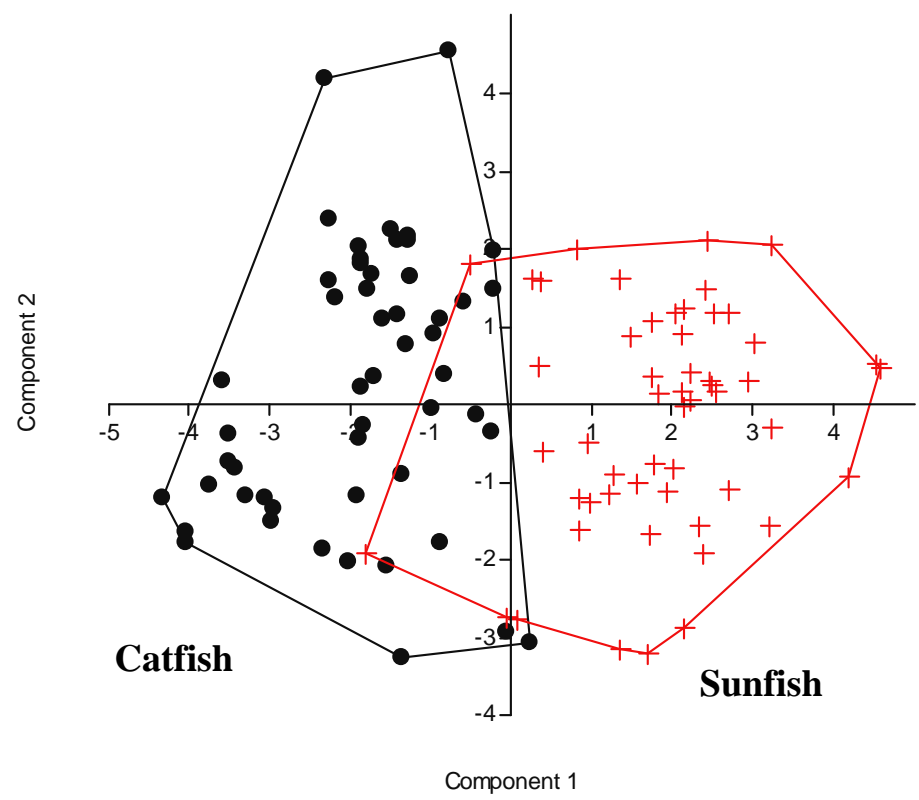

Fig. 13. Plot of principle components 1 and 2 for 53 catfish (circles) and 52 sunfish (plus signs) samples based on 20 of the most common PCB congeners. Polygons enclose every point for the two groups. 


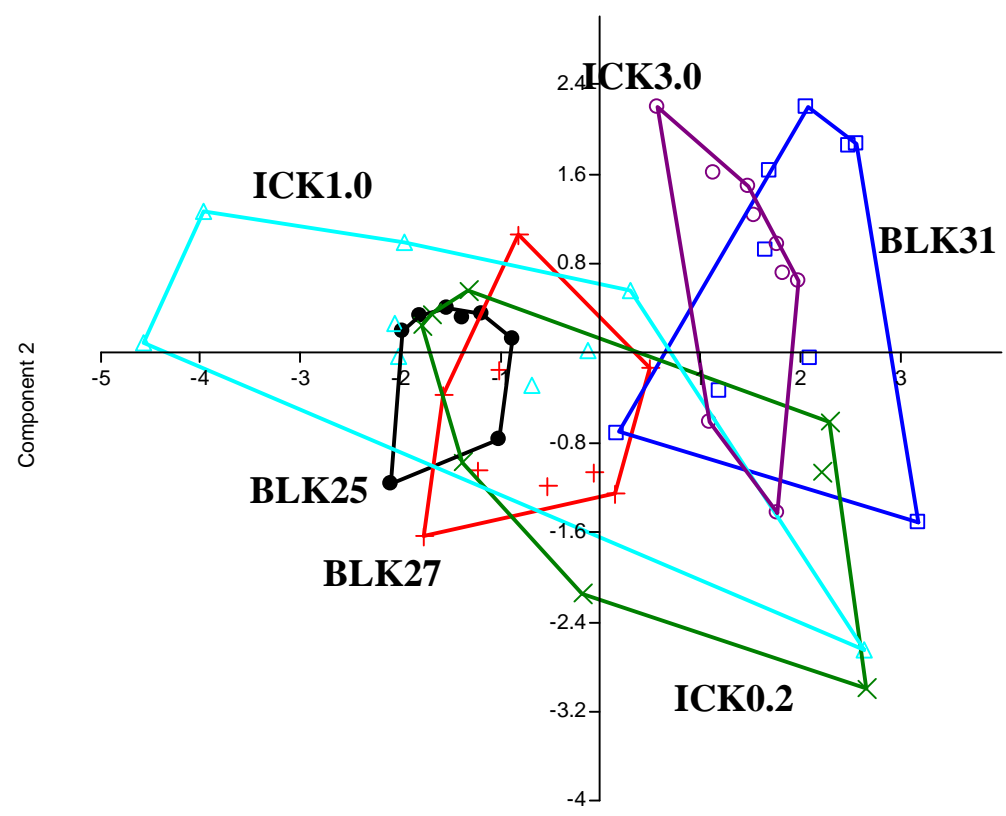

Component 1

Fig. 14. Plot of the first two principle component scores for 52 sunfish from 6 sites.

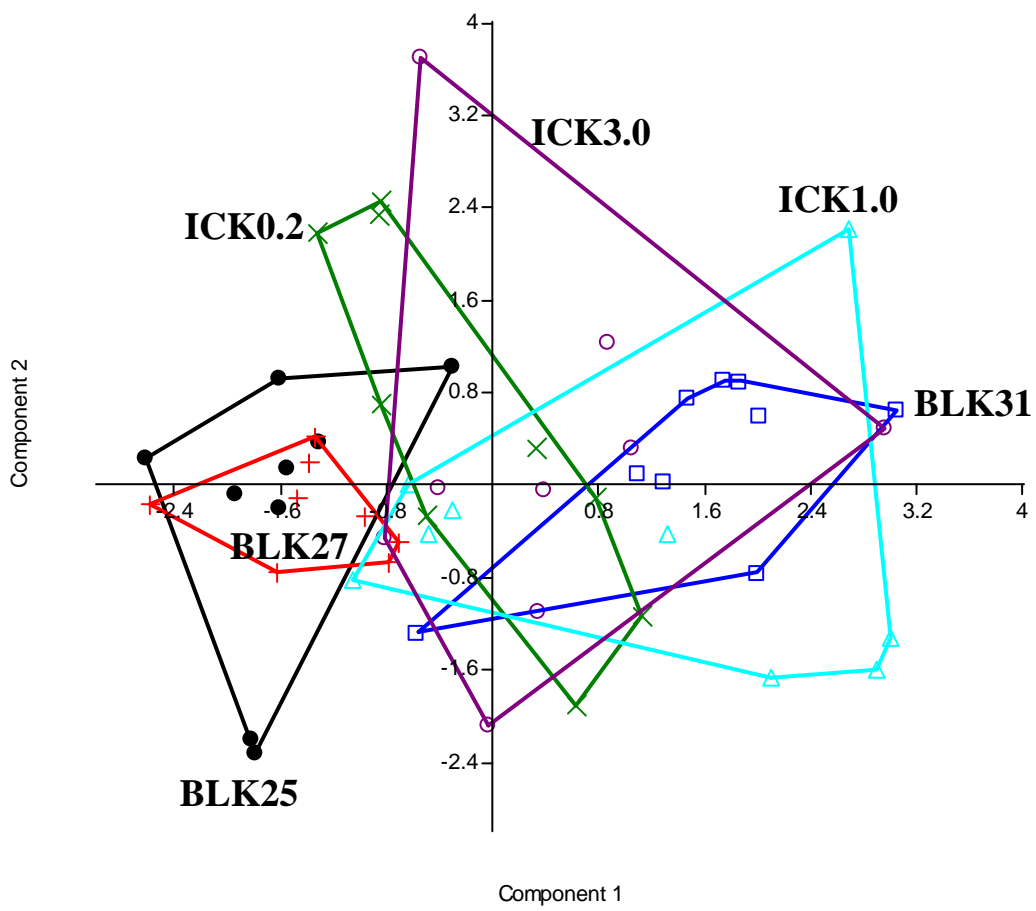

Fig. 15. Plot of the first two principle component scores for 53 catfish from 6 sites. 


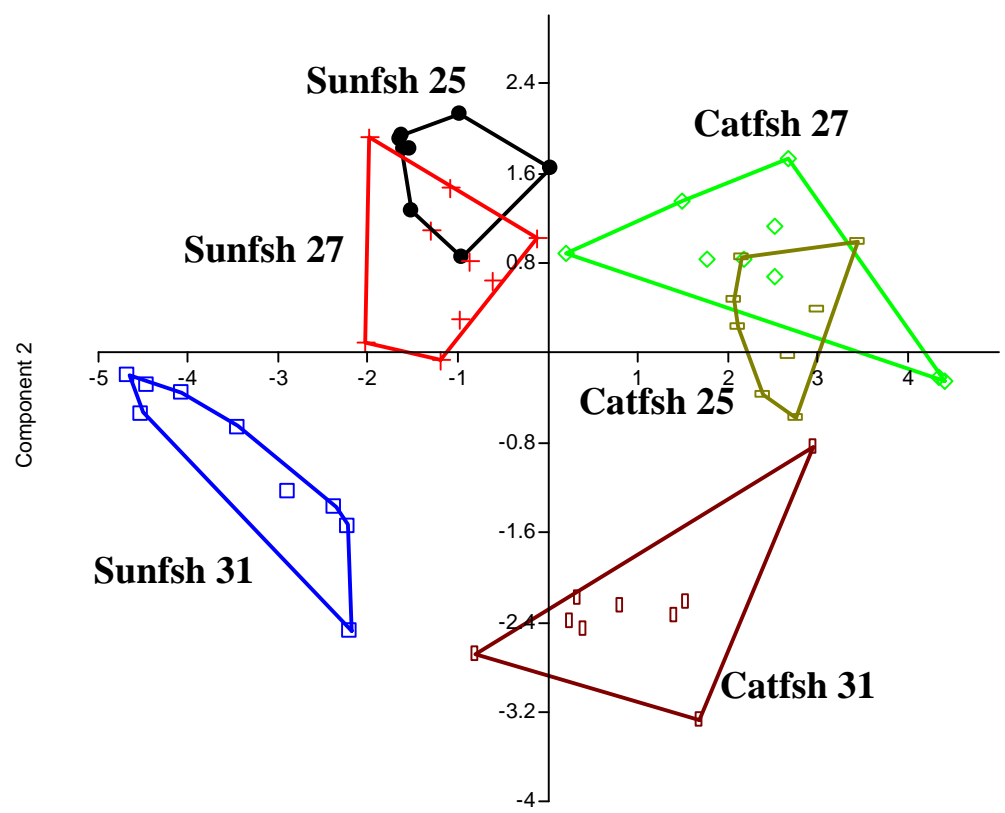

Component 1

Fig. 16. Plot of the first two principle component scores for sunfish and catfish from three Blue River sites (BLK 25, 27, and 31).

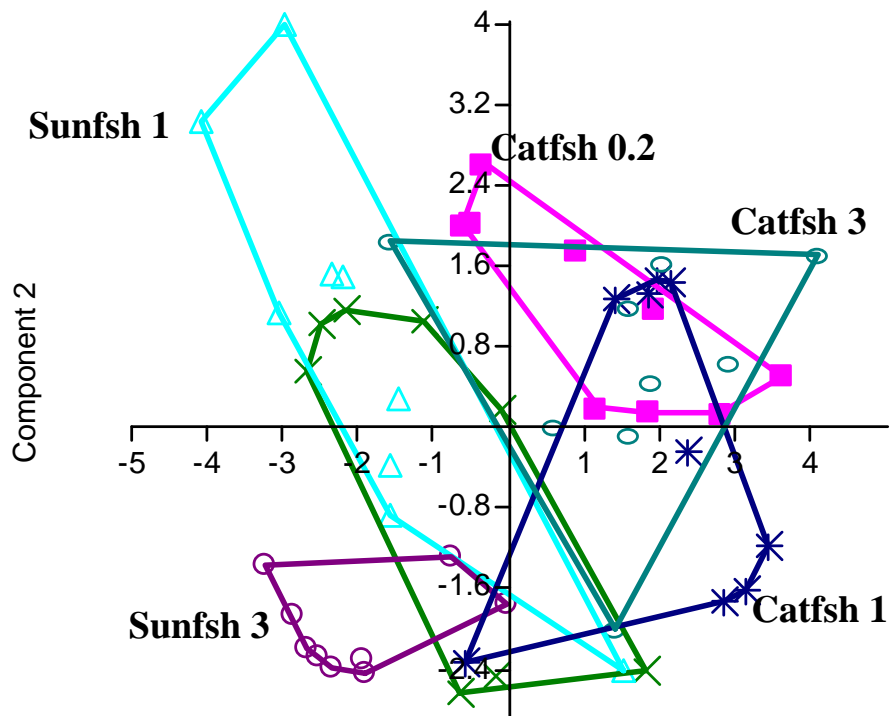

Sunfsh 0.2

Component 1

Fig. 17. Plot of the first two principle component scores for sunfish and catfish from three Indian Creek sites (ICK 0.2, 1.0, and 3.0). 


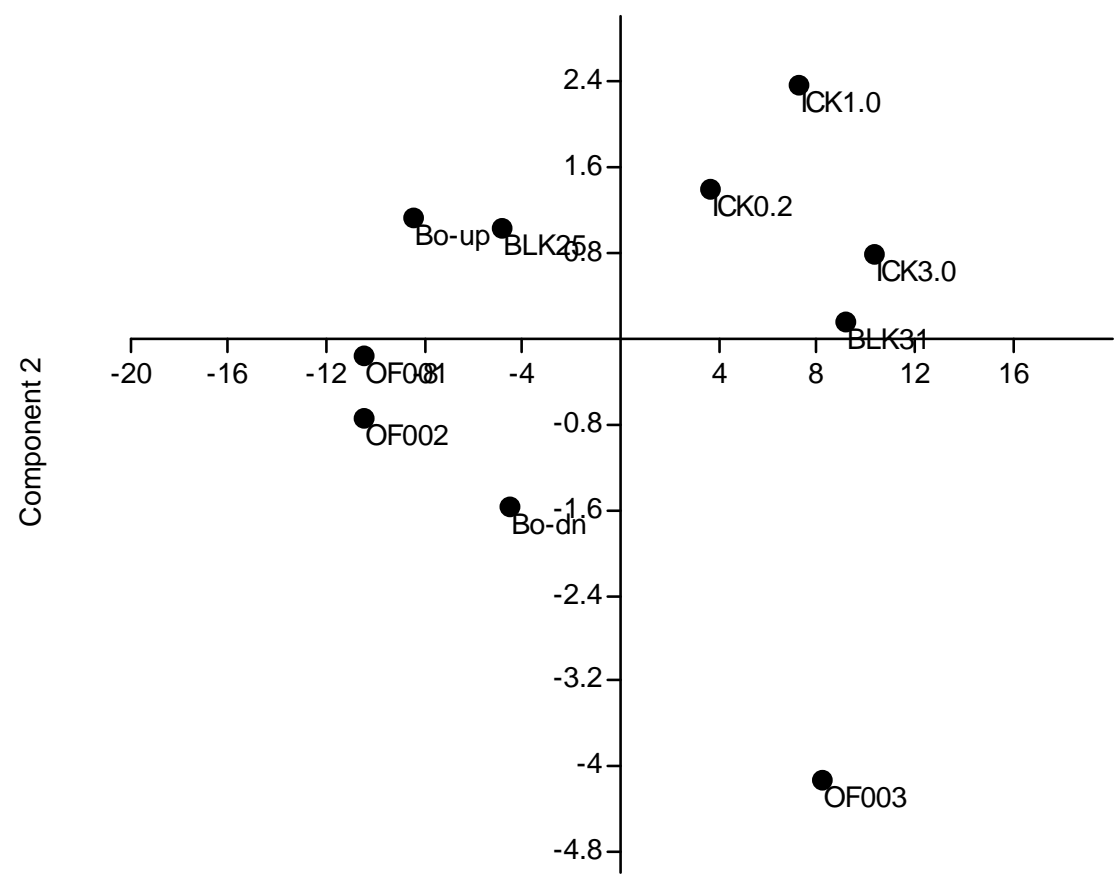

Component 1

Fig. 18. Plot of the first two principle components derived from 40 PCB congeners analyzed from SPMDs at 10 locations. 


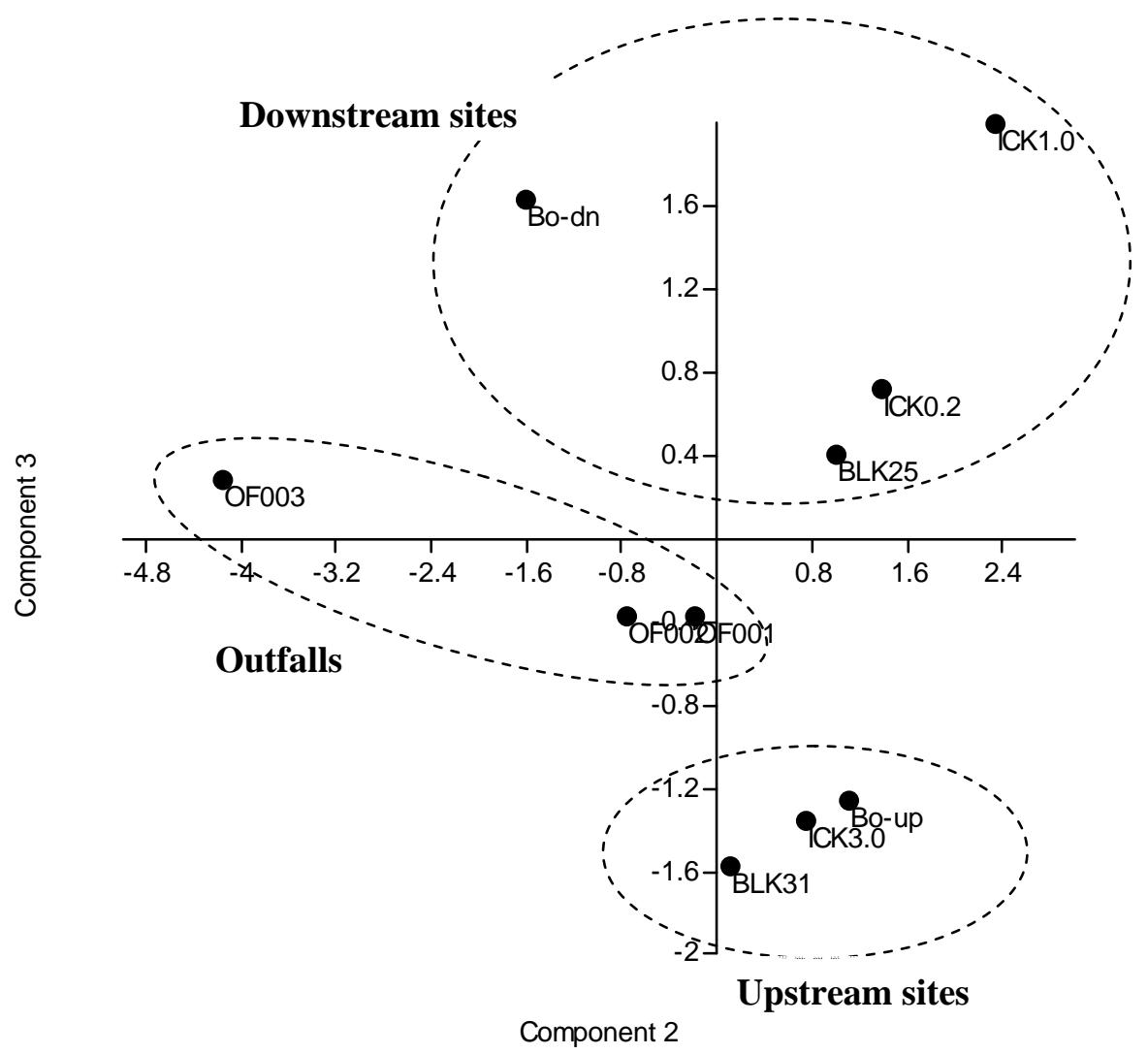

Fig. 19. Plot of the second and third principle components derived from 40 PCB congeners analyzed from SPMDs at 10 locations. 


\subsection{TEMPORAL TRENDS}

In general, PCB concentrations in green sunfish and channel catfish from Indian Creek and the Blue River near the KCP have decreased substantially since the early $1990 \mathrm{~s}$, even at the reference locations (Figures 20-28). If comparing levels reported in catfish from the Blue River in the mid-1980s $(1-2 \mu \mathrm{g} / \mathrm{g})$, and catfish in the Blue River in the early $1990 \mathrm{~s}(0.7-0.9 \mu \mathrm{g} / \mathrm{g})$, today's levels in fish are dramatically lower, averaging around $0.4 \mu \mathrm{g} / \mathrm{g}$ in catfish. The only two sites around the KCP that exhibit slightly higher concentrations in the 2000s relative to the early 1990s are ICK 0.2 and BCK 0.2.

At the sites downstream of KCP discharges, the 2007 fish are higher in PCBs than recent fish collections in 2002 and 2005, with the exception of BLK 25.0 and BCK 0.2 where the levels in 2007 were similar to 2005. Trending in Boone Creek is complicated by the need to collect very small individual fish in some years. Various factors could explain the PCB increase at most sites downstream of KCP in Indian Creek and the Blue River, including size differences between years as was discussed previously relative to the catfish. However, sunfish sizes were similar between years and slight increases were still evident in that species. PCBs did not increase in fish from reference sites (BCK 31.0 and ICK 3.0). Care should be taken to not over interpret small changes in PCB levels. In the case of both species the absolute change in recent years is extremely small (well less than $0.2 \mu \mathrm{g} / \mathrm{g}$ in most cases). PCB concentrations in fish from small streams exhibit substantial short-term changes, often increasing or decreasing more than $50 \%$ between semiannual sampling periods (Southworth et al 1997). A single high or low flow period may represent unusual conditions that may change PCB levels in fish.

The PCB congener data was used to make a comparison between the levels in 2005 and 2007 fish (Figure 29). Of the 209 PCB congeners, only the 12 dioxin-like congeners were analyzed in samples collected in 2005, and thus the comparison focuses on these congeners. Overall, the congener data is not unlike the pattern exhibited by the Aroclor analysis: levels appear to be slightly higher at most sites in 2007 than in 2005.

The advantage of the temporal comparisons herein is that multiple years of data are available. The major message of these comparisons is that PCBs in recent years are substantially down in fish from measured highs in the 1980s and 1990s. Over the 2002-2007 period, however, there is some evidence of a slight to modest increase in PCB fish levels at sites downstream of the KCP. Again, absolute change when comparing the 2007 data set to previous years (i.e., 2002 and 2005) is small. Interpreting data trends at relatively low levels in fish as seen in this study is complicated by weight bias of individuals collected, analytical variability, recent changes to stream flow, and other changes within the system being studied.

\subsection{KCP PCB LEVELS IN PERSPECTIVE}

PCBs are ubiquitous compounds in the aquatic environment, and the presence of low-level PCB concentrations in fish from urban streams like Indian Creek and the Blue River is not unexpected. In the US, PCBs were used in hundreds of commercial and industrial processes including electrical insulation, pigments for plastics, and plasticizers in paints. Over 1.5 billion pounds of PCBs were produced in the US prior to the ban on the manufacture and distribution of PCBs in the late 1970s. Once in the aquatic environment, PCBs are bioaccumulative and persistent compounds, and elevated levels in fish can be expected for many years. PCBs are second only to mercury in the number of lake acres (approximately 2 million) and river miles (approximately 120,000) in the US currently under a fish consumption advisory (EPA 2003). 

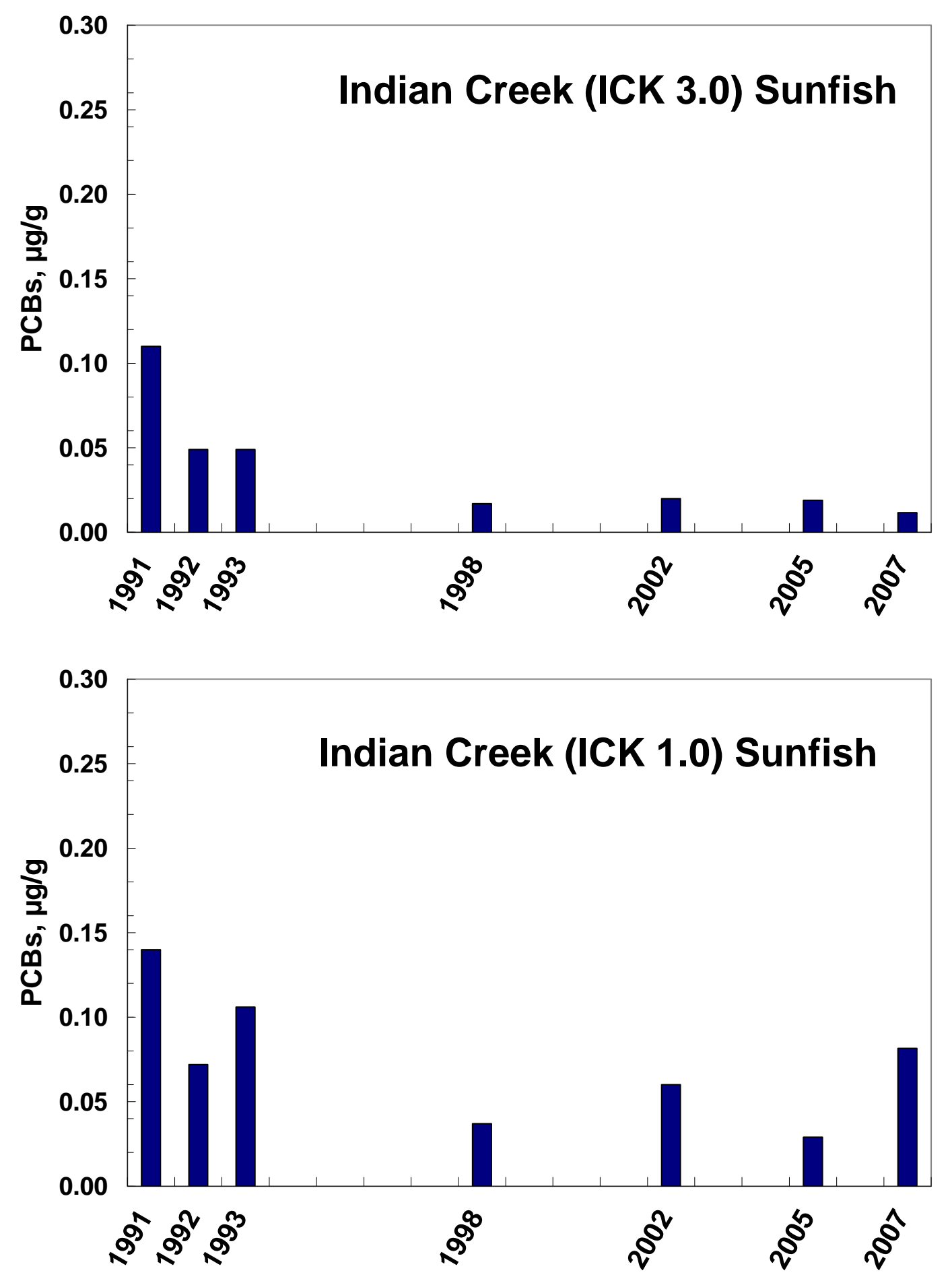

Fig. 20. Temporal changes in mean total $P C B$ concentrations in green sunfish in Indian Creek at sites upstream (ICK 3.0) and downstream of outfall 003/004 (ICK 1.0) at the U.S. Dept. of Energy Kansas City Plant, 1991- 2007. 


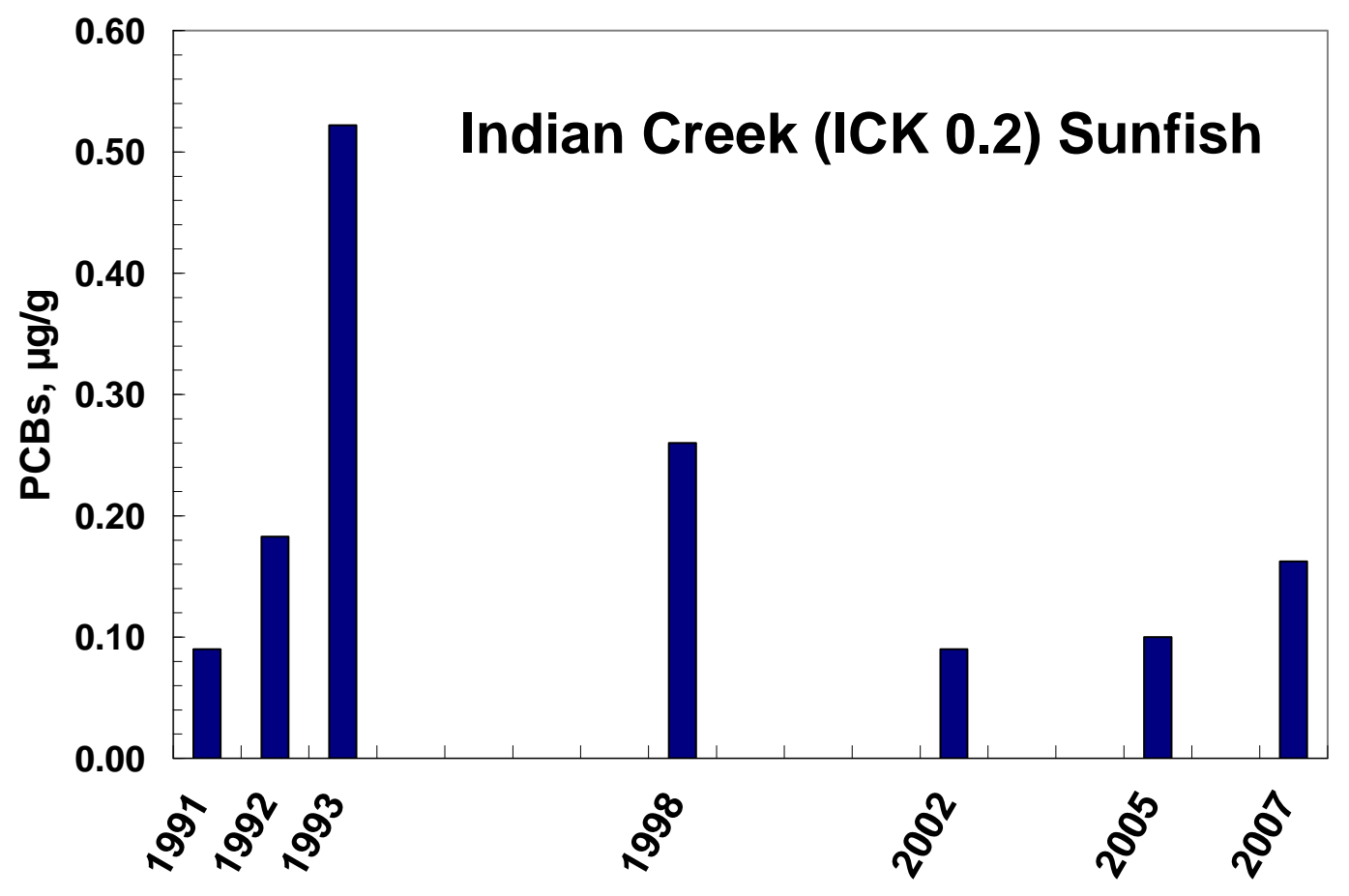

Fig. 21. Temporal changes in mean total PCB concentrations in green sunfish in Indian Creek at ICK 0.2, downstream of outfall 002 at the U.S. Dept. of Energy Kansas City Plant, 1991- 2007. Note: This figure has a different $y$-axis scale than Fig 21.

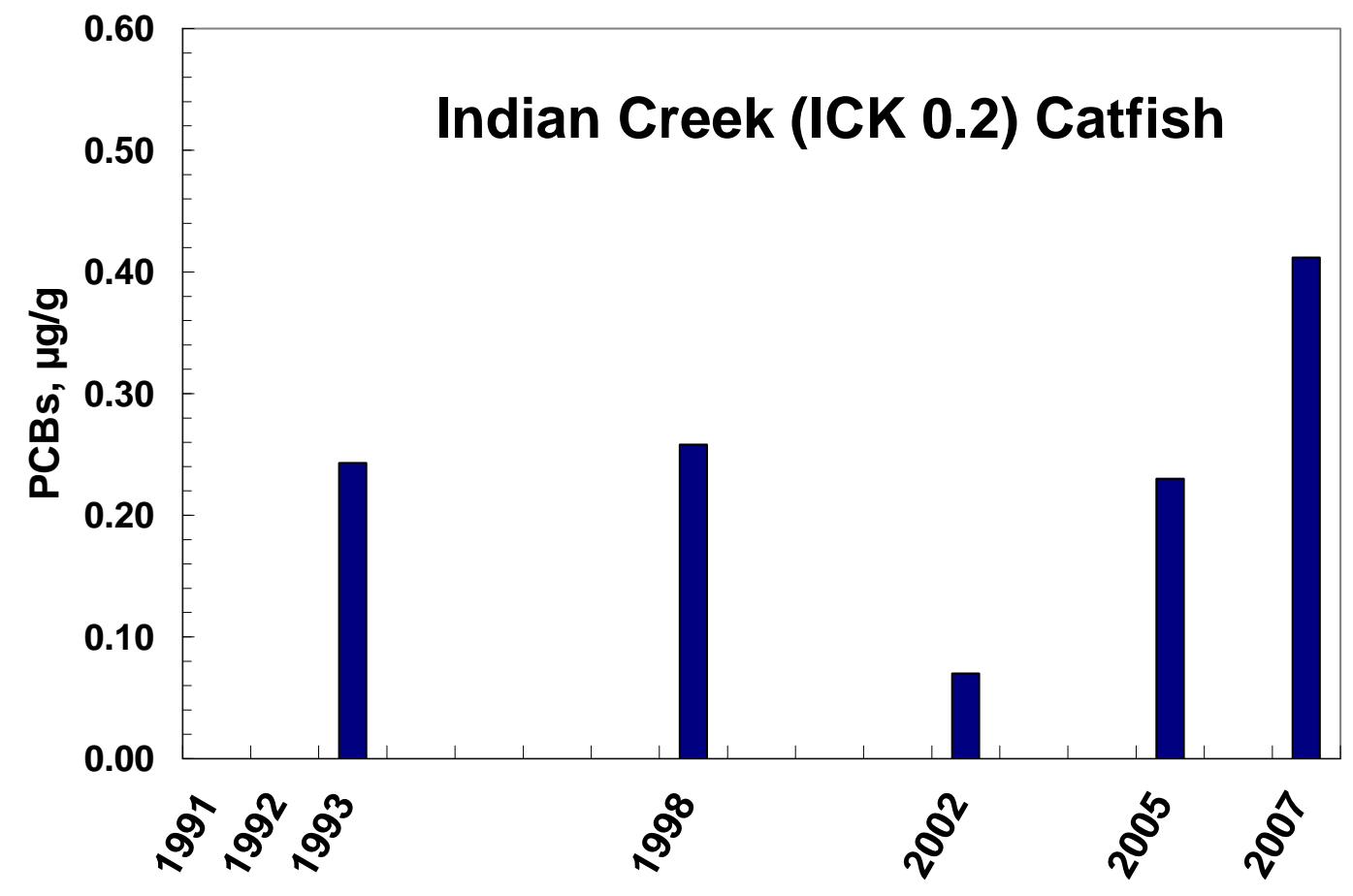

Fig. 22. Changes in mean total PCB concentrations in channel catfish at the lowermost Indian Creek site (ICK 0.2), downstream of outfall 002 near the U.S. Dept. of Energy Kansas City Plant, 1991- 2007. 

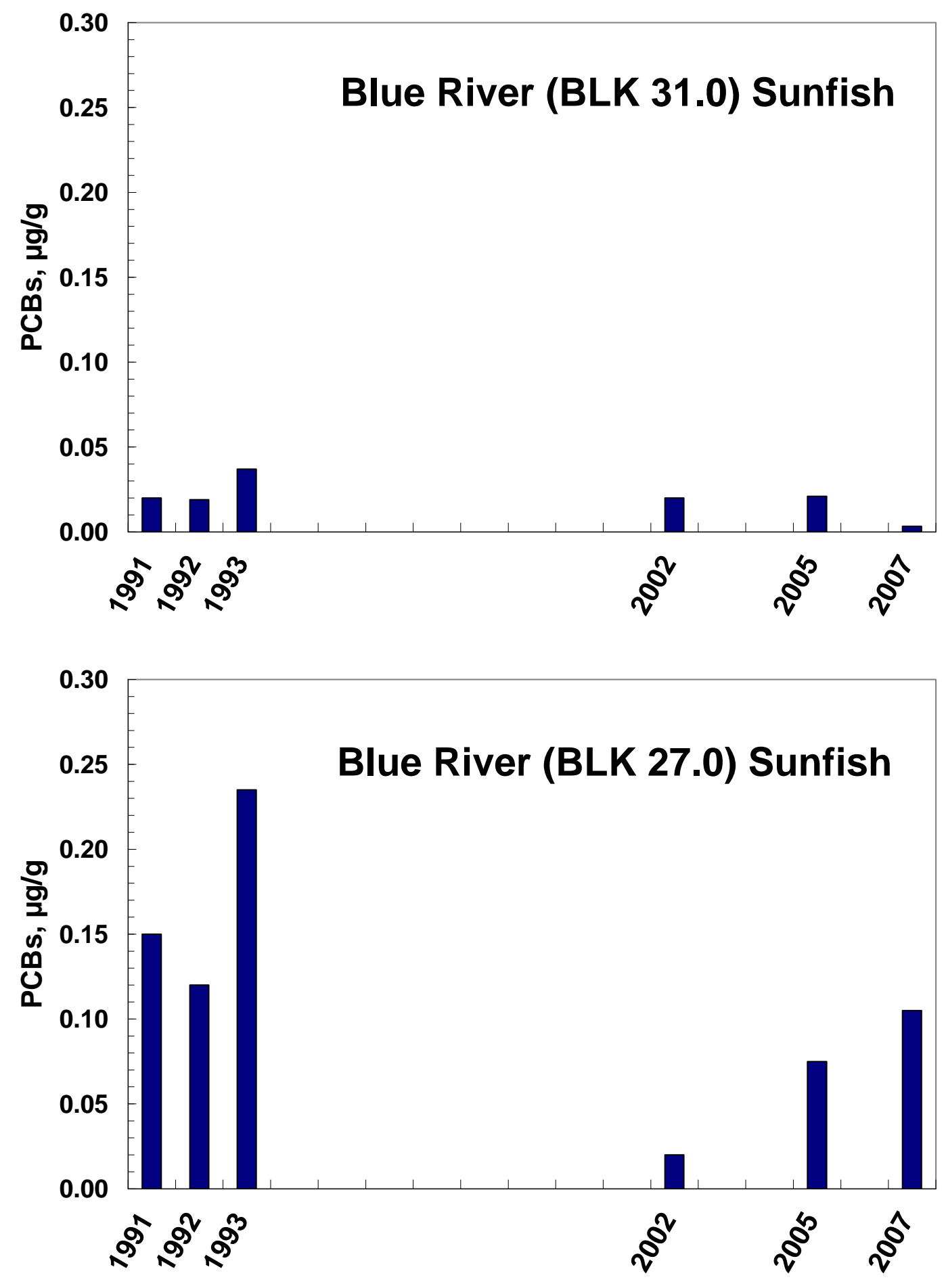

Fig. 23. Temporal changes in mean total PCB concentrations in green sunfish in the Blue River, upstream (BLK 31.0) and downstream (BLK 27.0) of the confluence of Indian Creek, 1991- 2007. 


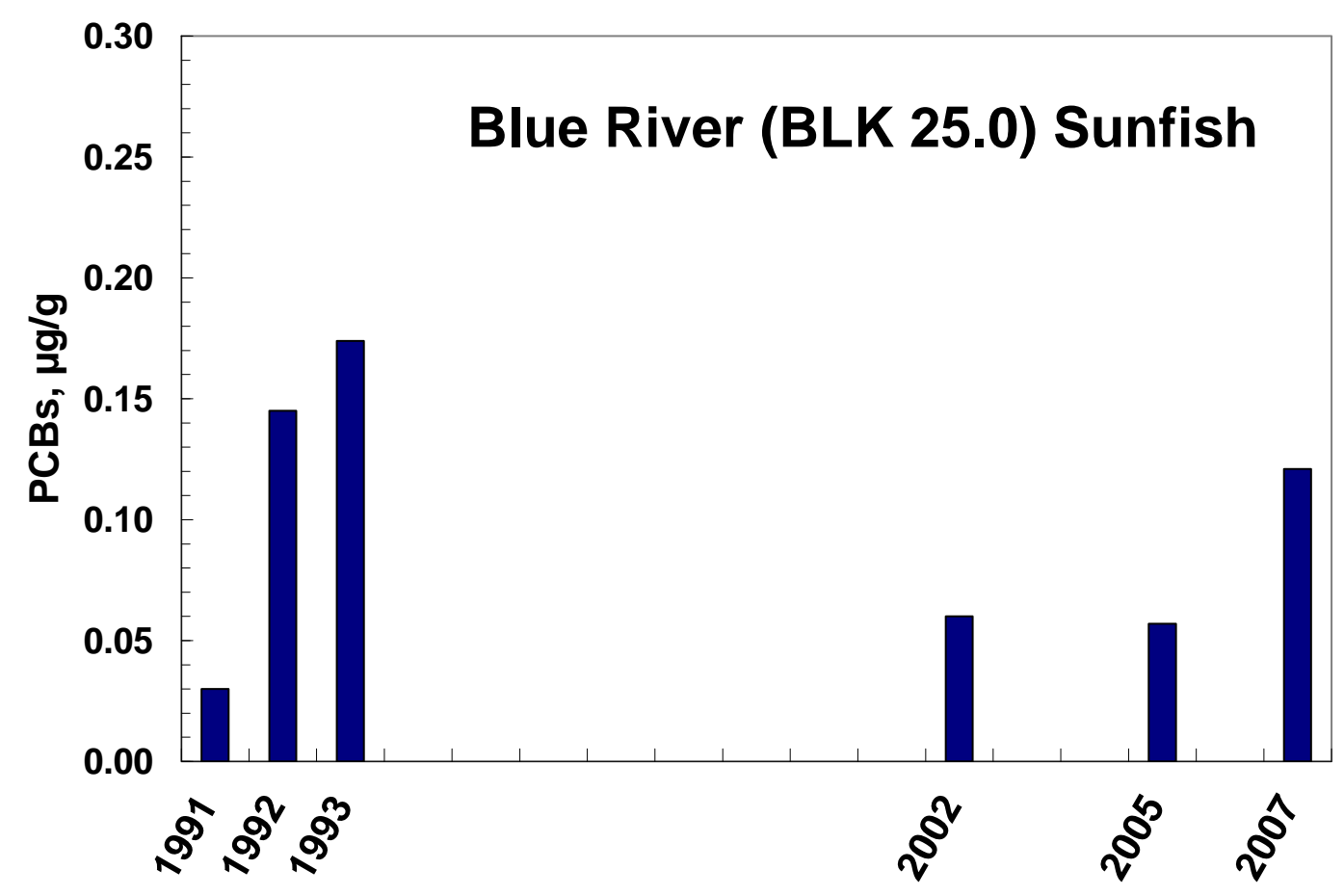

Fig. 24. Temporal changes in mean total PCB concentrations in green sunfish in the Blue River, downstream of the Indian Creek and Boone Creek confluences, 1991- 2007.

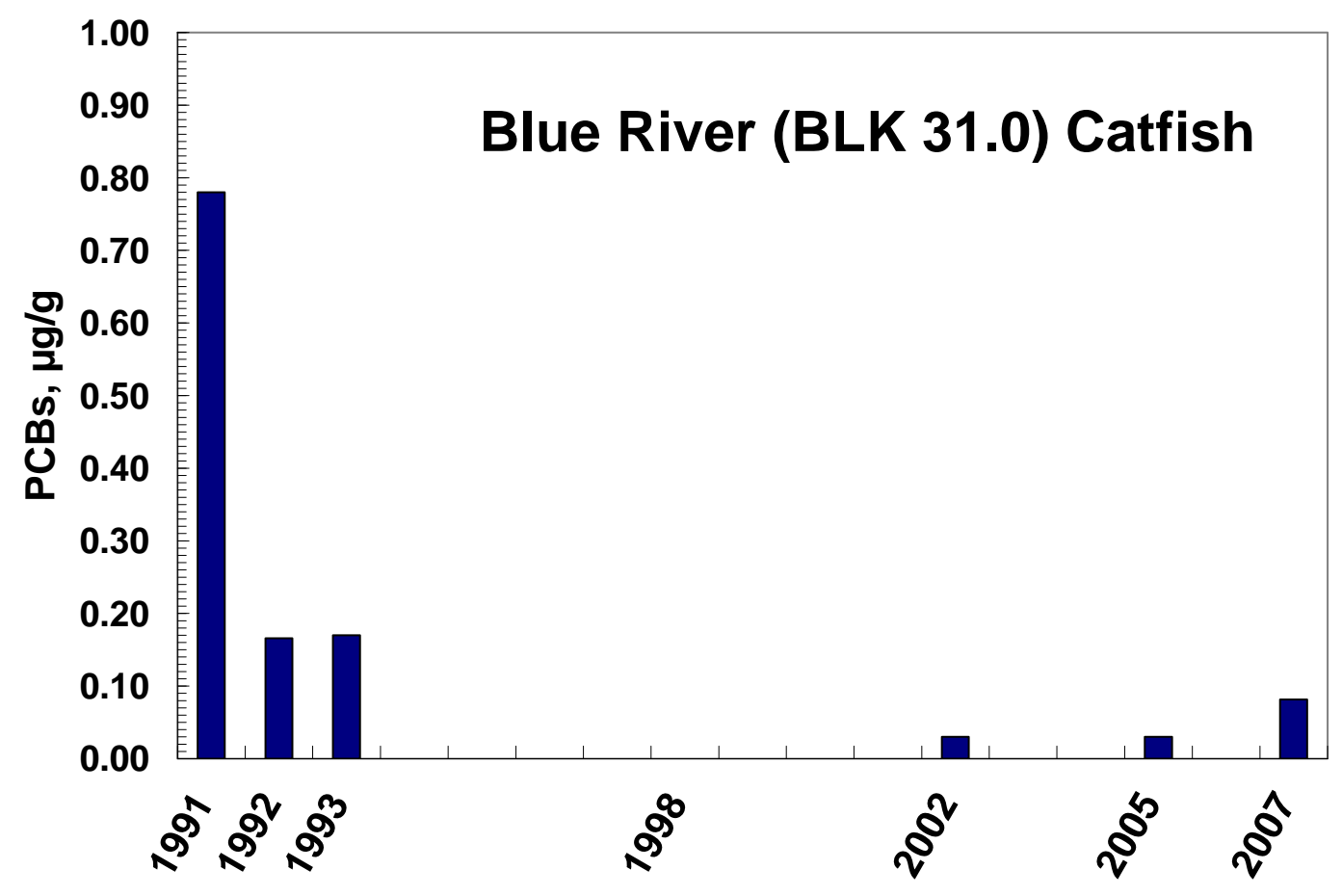

Fig. 25. Changes in mean total PCB concentrations in channel catfish at the uppermost Blue River sampling site, upstream of the U.S. Dept. of Energy Kansas City Plant, 1991- 2007. 


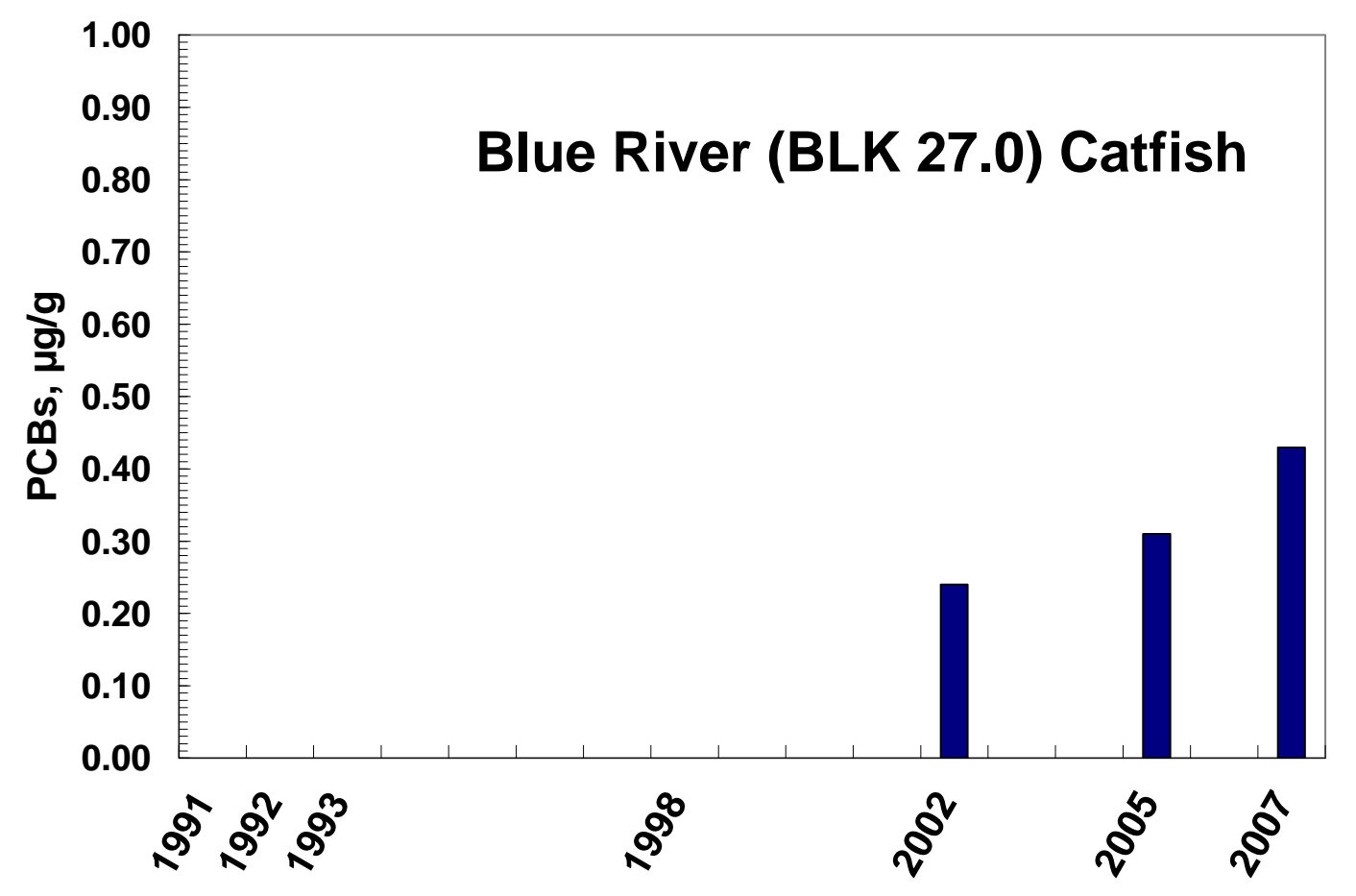

Fig. 26. Changes in mean total PCB concentrations in channel catfish in the Blue River downstream of the confluence with Indian Creek, 1991- 2007.

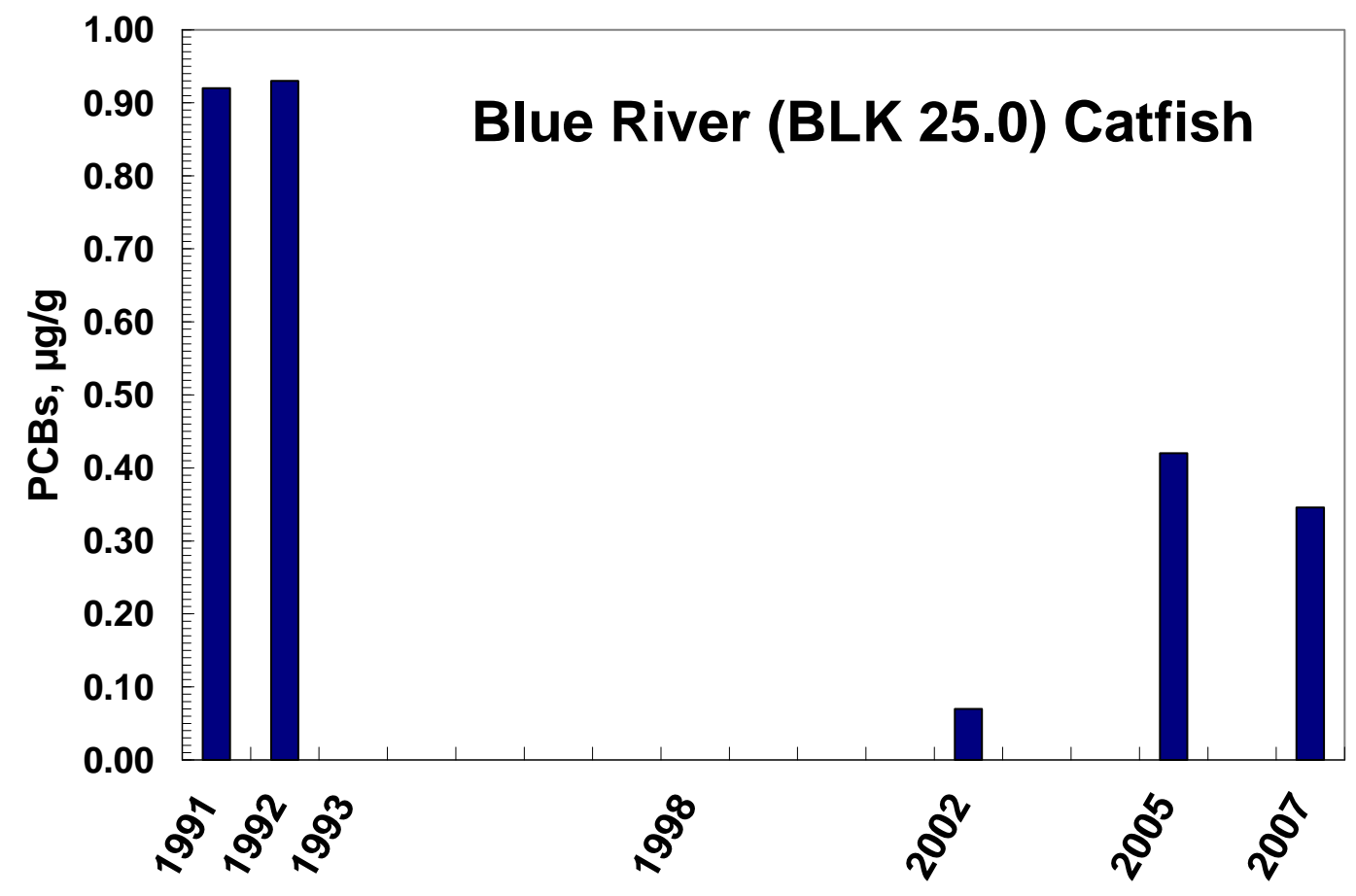

Fig. 27. Changes in mean total PCB concentrations in channel catfish in the Blue River downstream of the confluences with Indian Creek and Boone Creek, 1991- 2007. 


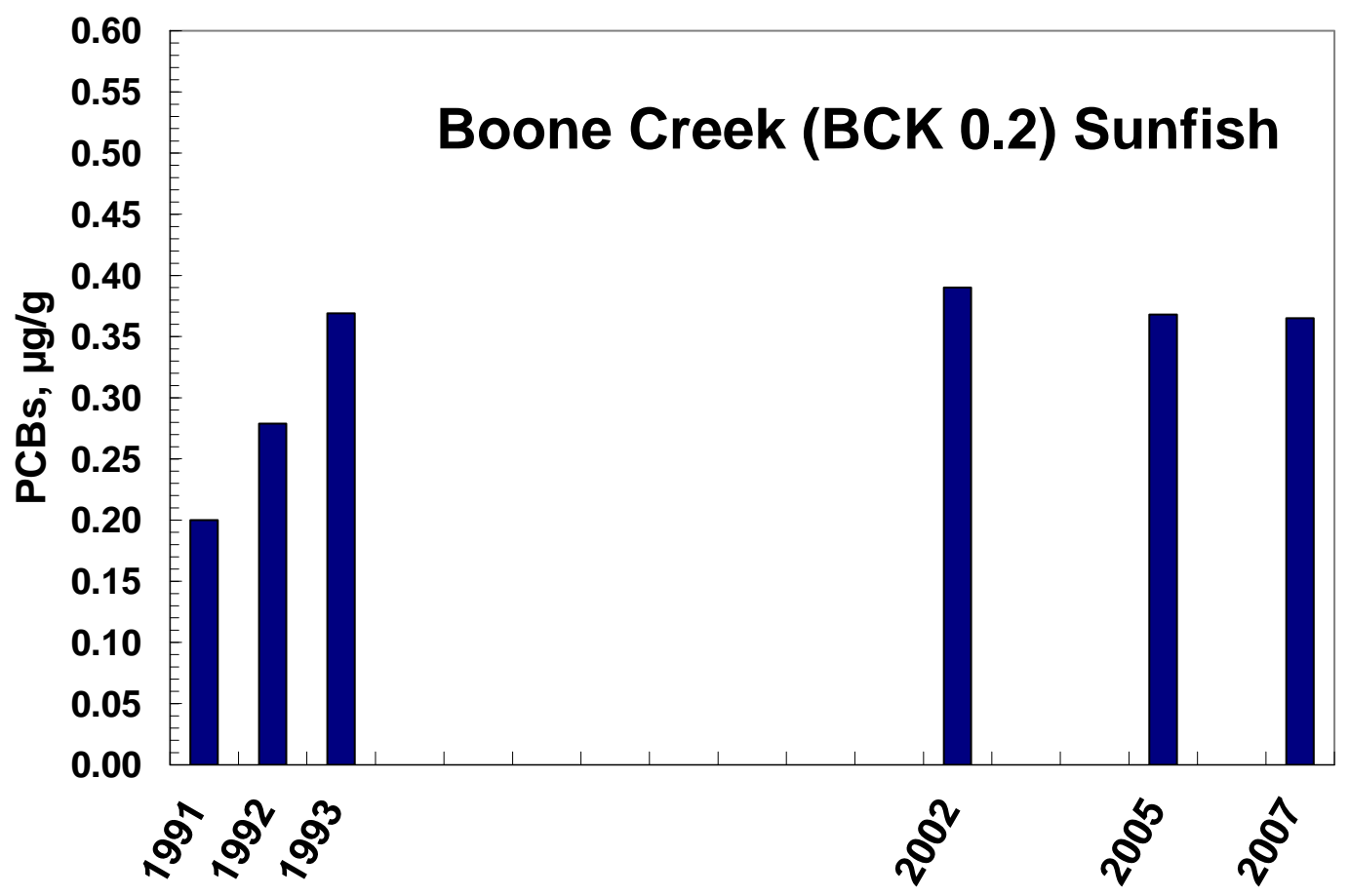

Fig. 28. Changes in mean total PCB concentrations in sunfish in Boone Creek at a site downstream of the U.S. Dept. of Energy Kansas City Plant, 1991- 2007. 

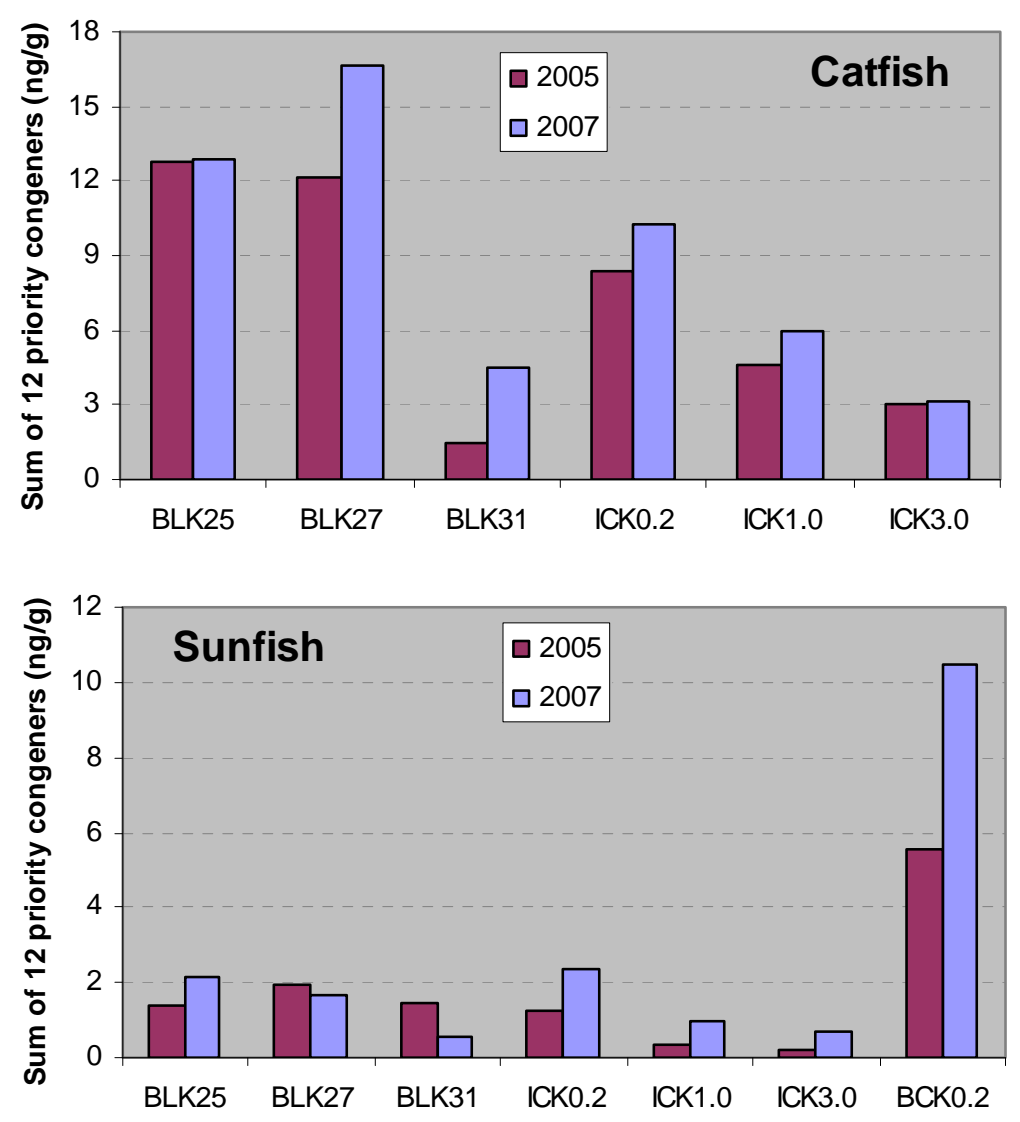

Fig. 29. Mean sum of 12 dioxin-like congeners for sunfish and catfish in 2005 and 2007 at seven sites (see also Table 3). 
In EPA's National Fish Tissue Study (1999-2000) all 143 sites surveyed had detectable PCB levels in fish. Of 362 sites sampled by EPA in their National Study of Chemical Residues in Fish (EPA 1992), the median concentration in fish tissue was $0.21 \mu \mathrm{g} / \mathrm{g}$ total PCBs, and $25 \%$ of the sites monitored exceeded 1 $\mu \mathrm{g} / \mathrm{g}$ in fish. The median concentration of total PCBs in whole fish collected from 100 urban streams over the 1992-2001 period by the USGS National Water Quality Assessment Program was $0.14 \mu \mathrm{g} / \mathrm{g}$ (USGS 2003). Fish from the most highly contaminated sites in the US, particularly large fatty fish like channel catfish, carp, and largemouth bass, often exceed $2 \mu \mathrm{g} / \mathrm{g}$ (the FDA threshold limit) and can be as high as 50 ppm (USGS 2003; EPA 1992). Thus, the levels of PCBs in fish near the KCP, ranging from approximately 0.1 to $0.45 \mu \mathrm{g} / \mathrm{g}$, are at or below national norms for urban streams.

There is considerable scientific and regulatory disagreement regarding the level of human health concern associated with PCB-contaminated fish. The differences in opinion regarding perceived risks to the public are highlighted by the differences in the US regulatory agencies' PCB threshold limits in fish. Using the cancer health endpoint, EPA recommends no consumption of fish when PCB values in fish are $>0.1$; however, FDA sets the "no sale of commercial fish across state lines" threshold at $\geq 2 \mu \mathrm{g} / \mathrm{g}$ (20 times higher). Both regulatory agencies point out that that there are considerable health benefits from eating fish that are not considered in conventional risk analyses.

Given the somewhat conflicted federal guidance, States have dealt with the potential PCB risks associated with fish in very different ways. Some states have used EPA guidance as a basis for issuing detailed consumption limits for specific sites, even when PCB levels are very low. Other states have adopted statewide approaches that attempt to educate the public on overall ways to reduce risks (e.g., cutting off fatty tissue, grilling fish), and limit site-specific advisories to the most highly contaminated sites. In the case of Indian Creek and the Blue River, levels of PCBs in fish are such that the Missouri Department of Health and Senior Services has posted advisories to encourage people to limit consumption based on the species and size of the fish (DHSS 2008). At the KCP, warning signs are also posted for the four regulated outfalls and on Indian Creek near outfall 002.

The magnitude of the risks to people who eat fish is highly dependent on a number of factors, including the species of fish, fish size, type of consumer (e.g., children, pregnant women), and the total consumption of fish per month/year. Using standard risk assessment assumptions, EPA has established recommended consumption limits based on ranges of PCBs in fish tissue (EPA 1999). Based on EPA's reference dose $\left(2 \times 10^{-5} \mathrm{mg} / \mathrm{kg}\right.$-d $)$ and cancer slope factor $(2$ per $\mathrm{mg} / \mathrm{kg}-\mathrm{d})$, some limits to eating fish would be recommended for almost all game fish in US lakes and rivers, since most of these fish species would be expected to contain greater than $0.0015 \mu \mathrm{g} / \mathrm{g}$ of PCBs. Using general EPA risk guidance, fish containing $0.05 \mu \mathrm{g} / \mathrm{g}$ PCBs (a level similar to Indian Creek fish averages) could be safely consumed at a rate of one 4-ounce meal per month (equivalent to 6 eight-ounce meals per year). Identification of specific risks associated with eating Indian Creek or Blue River fish is highly dependent on the assumptions used in the risk analysis.

Conventional risk analysis for PCBs uses the same assumption of carcinogenic risk (Slope Factor) for all PCBs, irrespective of what specific congeners comprise the mixture. Thus, $1 \mathrm{ppm}$ of Aroclor 1242 in fish is assumed to pose the same carcinogenic risk as $1 \mathrm{ppm}$ of Aroclor 1254, or $1 \mathrm{ppm}$ of total PCBs (sum of all congeners or Aroclor mixtures). However, the fraction of any commercial PCB mixture made up of dioxin-like PCB varies widely among the various Aroclor mixtures, peaking within Aroclor 1254 (18\% dioxin-like congeners). Less chlorinated mixtures such as those used at KCP have much lower contents of these highly toxic congeners. The list below was calculated from data obtained from the USEPA (Frame et al. 1996): 
$\underline{\text { Mixture }}$

Aroclor 1016

Aroclor 1242

Aroclor 1248

Aroclor 1254

Aroclor 1260
\% toxic congeners

$<0.01$

1.5

4.6

18.0

1.4

Most of the toxicity and carcinogenic risk associated with PCB mixtures arises from a small number of PCB congeners whose chemical structures and toxicological mode of action resemble that of 2,3,7,8 tetrachlorodibenzodioxin, commonly referred to as TCDD or 'dioxin'. TCDD is the most toxic of a class of highly toxic chlorinated organic compounds known as chlorinated dibenzodioxins and chlorinated dibenzofurans. The toxicity of the constituents of this group, as well as the 'dioxin-like' PCBs, has been evaluated by EPA and normalized to TCDD, using a 'Toxicity Equivalent Factor', or TEF. In this scheme, TCDD would have a TEF of 1 , and other dioxin-like chemicals factors of 1 or less. The dioxinlike PCBs generally have TEF's of 0.0001 to 0.0005 , with two congeners (PCB-126 and PCB-169) having higher values ( 0.1 and 0.01 , respectively). Within mixtures such as environmental PCB extracts, the concentration of each of the 12 dioxin-like PCB congeners is multiplied by its TEF to generate a Toxic Equivalent (TEQ). The TEQ's of the mixture's components can then be summed to yield a single value that can be used in risk analyses. Because concentration of the dioxin-like PCBs was relatively low, the average TEQ values for fish downstream of the facility are also low ( 0.009 to 0.017 for catfish and 0.0050 to 0.0065 for sunfish; Table 3).

Dioxin equivalents of toxic PCBs (TEQ) in sunfish were similar among sites, with no obvious trend between reference sites and KCP sites when setting non-detects at half the detection limit (Figure 30), though among site differences are suggested when non-detects are set equal to 0 (Table 3 ). In catfish, TEQs were higher than reference sites in lower Indian Creek (ICK 0.2) and the two Blue River sites, consistent with the total PCB spatial patterns (Figure 31).

Because PCB mixtures arising from the injection molding process at KCP were similar to Aroclor 1242, it has been presumed that PCBs accumulated by fish in Indian Creek and the Blue River downstream from KCP would contain a lower fraction of toxic congeners than would be expected from analysis of Aroclor standards. The congener data were used to evaluate the true relative concentration of dioxin-like congeners compared to what might be expected based on Aroclor concentrations.

In a comparison of the percent of dioxin-like congeners in biological samples from sites downstream from $\mathrm{KCP}$ with expected values from the mean ratio of PCB Aroclors in those samples, the toxic content of the fish is 20 to $40 \%$ of the expected value (Table 5). The fraction of total PCBs constituted by dioxin-like congeners in streams near the KCP ranged from 2 to $4 \%$. As a point of reference, the mean percent of dioxin-like congeners in PCB-contaminated fish from the Great Lakes ranged from 5 to $10 \%$ (Hickey et al. 2006).

Thus, PCBs in fish downstream from KCP were less toxic than predicted from their Aroclor composition. Presumably that difference should be reflected in a risk analysis based on TEQs rather than total PCBs. However, conventional risk assessment methodology for PCBs does not allow the use of TEQs, but instead uses methods based on total PCBs. Total PCB approaches to risk assessment are likely to be more conservative than direct congener-based analyses. 
Table 5. Comparison of observed and expected toxicity of PCB mixtures in fish from sites near KCP (reference sites excluded). Expected and observed \% toxic congeners are concentration based for 12 toxic congeners.

\begin{tabular}{|l|c|c|c|c|c|}
\hline \multicolumn{1}{|c|}{ Species } & $\begin{array}{c}\text { Aroclor percent } \\
\mathbf{1 2 4 8 / 1 2 5 4 / 1 2 6 0}\end{array}$ & $\begin{array}{c}\text { Expected \% } \\
\text { toxic congeners }\end{array}$ & $\begin{array}{c}\text { Observed \% } \\
\text { toxic congeners }\end{array}$ & $\begin{array}{c}\text { KCP } \\
\text { TEQ }\end{array}$ & $\begin{array}{c}\text { Reference } \\
\text { TEQ }\end{array}$ \\
\hline Sunfish & $61 / 38 / 1$ & 9.4 & 1.8 & 0.006 & 0.007 \\
\hline Catfish & $47 / 39 / 14$ & 9.7 & 4.0 & 0.012 & 0.006 \\
\hline
\end{tabular}

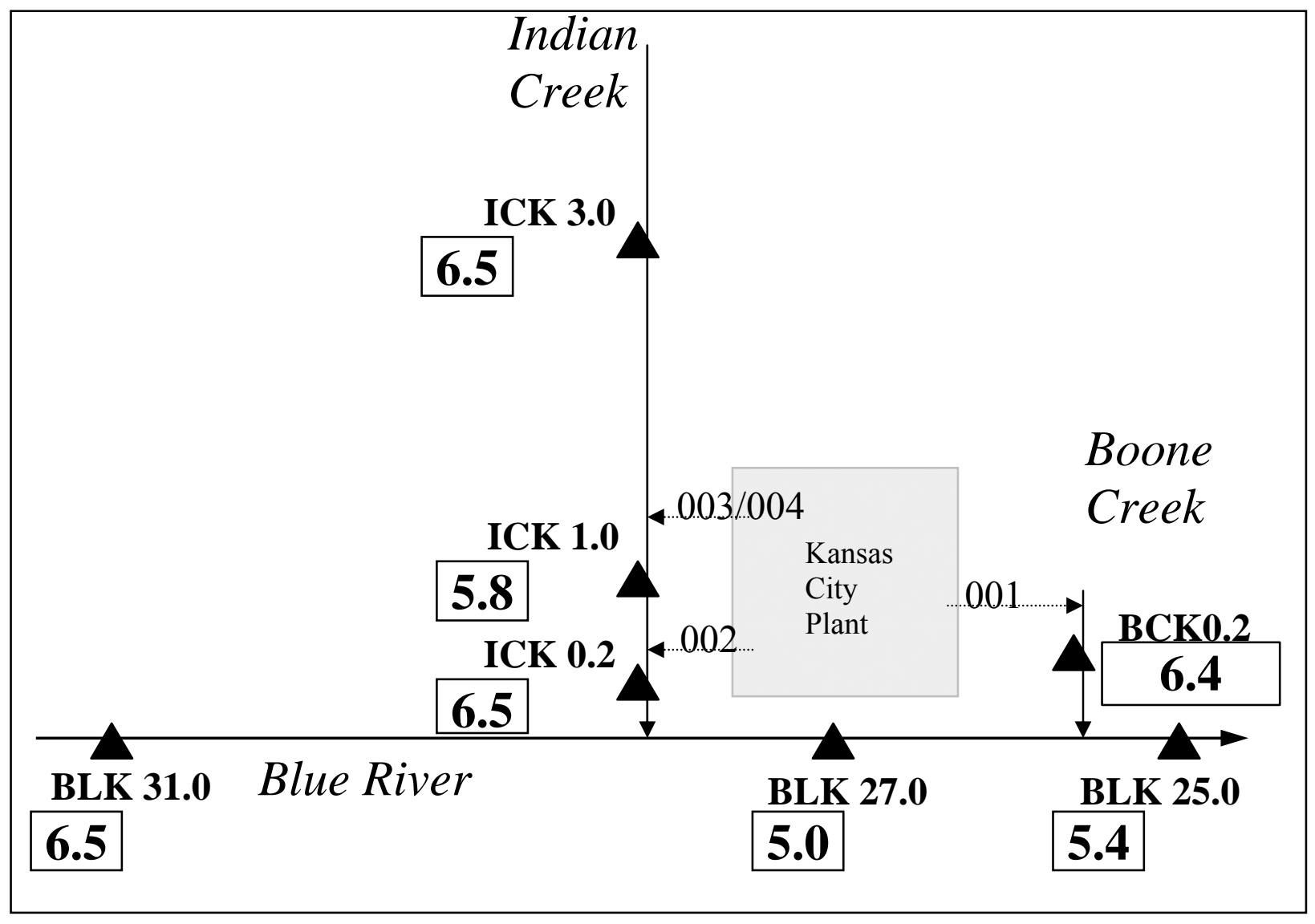

Fig. 30. Mean concentrations (ng/kg) of dioxin toxic equivalents (TEQs) in green sunfish, 2007. 


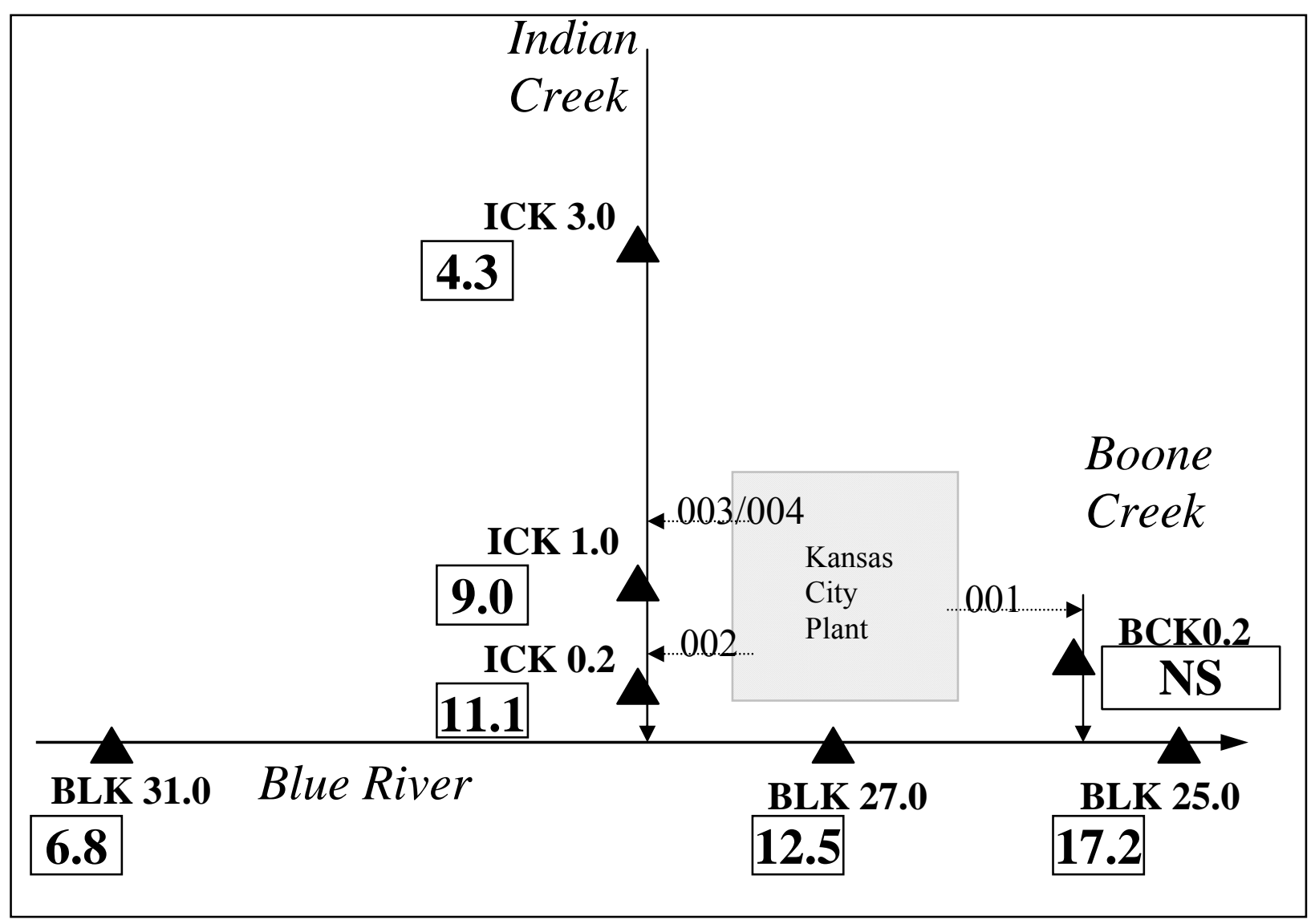

Fig. 31. Mean concentrations (ng/kg) of dioxin toxic equivalents (TEQs) in channel catfish, 2007. 



\section{CONCLUSIONS}

The concurrent monitoring of a variety of biotic and abiotic media for the present study, across a number of sites upstream and downstream of KCP discharges, provides a valuable picture of PCB exposure and bioaccumulation in Indian Creek and the Blue River. Similar patterns of contamination, both spatially and temporally, were observed across species and media, providing additional confidence in the observed values.

Following are some key conclusions that can be drawn from this study:

- PCB concentrations in Indian Creek and Blue River fish are relatively low, and similar to many national urban sites. Potential risks to humans who eat fish from Indian Creek or the Blue River is highly dependent on assumptions used in the risk analysis.

- Concentrations of highly toxic dioxin-like PCB congeners in fish from sites near KCP are lower than would be predicted from Aroclor analysis of PCBs. Risk analyses based on the toxicity of standard Aroclor mixtures may overestimate risks associated with PCBs at this site.

- The spatial pattern of PCB contamination in fish, coupled with statistical analyses of the congener pattern in fish, continues to indicate that the KCP vicinity contributes to the PCB body burdens of fish in the receiving streams.

- The presence of PCBs in fish near the KCP is at least partially due to other sources of PCBs to the watershed, as evidenced by detectable levels of PCBs in biota upstream of the plant.

- The levels of PCBs in fish in 2007 are substantially lower than the levels observed in the mid-1980s and early 1990s, but have exhibited a slight increase over the 2002-2007 time period.

- It is clear from the congener data which congeners are being released from the facility area.

- Analysis of the congener data reveals that most of the PCB load in the environment is not comprised of congeners recognized as being highly toxic.

- The multivariate approach taken to analyze the congener data indicates that there are differences in the pattern of congeners between species and among the upstream reference and downstream impacted sites.

- When converted to dioxin-like toxic equivalencies, the risk is relatively low. 



\section{REFERENCES}

Ashwood, T.L., and M.J. Peterson. 1994. Polychlorinated Biphenyls and Pesticides in Fish from Streams near the U.S. Department of Energy's Kansas City Plant: 1993 Report. Draft ORNL/TM-12892. Oak Ridge, Tennessee.

Ashwood, T.L., G.R. Southworth, and M.J. Peterson. 1993. Polychlorinated Biphenyls and Pesticides in Fish from Streams near the U.S. Department of Energy's Kansas City Plant. ORNL/TM-12298. Oak Ridge National Laboratory, Oak Ridge, Tennessee.

Ashwood, T.L., and M. J. Peterson. 1994. Polychlorinated Biphenyls and Pesticides in Fish from Streams near the U.S. Department of Energy's Kansas City Plant: 1993 Report. ORNL/TM-12892. Oak Ridge National Laboratory, Oak Ridge, Tennessee.

Ashwood, T.L. 1998. Polychlorinated Biphenyl Concentrations in Fish from Indian Creek. Letter Report from T.L. Ashwood, Oak Ridge National Laboratory, to A.D. Laase, DOE Kansas City Plant, September $14,1998$.

Betzen, G.A. 1995. Review of General Investigation of Flood Damage Reduction for Blue River at Dodson Industrial District, Draft Feasibility report and Environmental Assessment, October 1995. Letter from G.A. Betzen, DOE Kansas City Plant, to J. Lilley, U.S. Army Corps of Engineers-Kansas City, December 19, 1995.

Carlson, G. 2002. Health Department Adviser Missourians on Fish Safety. News Release, July 25, 2002. Missouri Department of Health, Jefferson City Missouri.

DHSS (Department of Health and Senior Services). 2008. Missouri Department of Health and Senior Services 2008 Fish Advisory, A Guide to Eating Missouri Fish. Internet accessed, December 17, 2008: http://www.dhss.mo.gov/NewsAndPublicNotices/2008/08FishAdvisory.pdf.

EPA (U.S. Environmental Protection Agency). 1986. Test Methods for Evaluating Solid Waste. SW-846, Third Edition. Office of Solid Waste and Emergency Response, U.S. Environmental Protection Agency, Washington, D.C.

EPA (U.S. Environmental Protection Agency). 1992. National Study of Chemical Residues in Fish, Volume I. EPA 823-R-92-008a, Office of Science and Technology, Washington, D.C.

EPA (U.S. Environmental Protection Agency). 1995. Guidance for Assessing Chemical Contaminant Data for Use in Fish Advisories. Volume 1, Fish Sampling and Analysis, Second Edition. EPA 823-R-95007. Office of Water, U.S. Environmental Protection Agency, Washington D.C.

EPA (U.S. Environmental Protection Agency). 1999. Polychlorinated Biphenyls (PCBs) Update: Impact on Fish Advisories EPA-823-F-99-019. Office of Water, U..S. Environmental Agency, Washington, D.C.

EPA (U.S. Environmental Protection Agency). 1999. Method 1668, Revision A: Chlorinated Biphenyl Congeners in Water, Soil, Sediment and Tissue by HRGC/HRMS. EPA 821-R-00-002. Office of Water, U.S. Environmental Protection Agency, Washington D.C. 
EPA (U.S. Environmental Protection Agency). 2003. EPA Fact Sheet. Polychlorinated Biphenyls (PCBs) Update: Impact on Fish Advisories. EPA 823-F-99-019. Office of Water, U.S. Environmental Protection Agency, Washington D.C.

EPA (U.S. Environmental Protection Agency). 2003. EPA Fact Sheet. EPA Update: National listing of Fish and Wildlife advisories. EPA 823-F-03-003. Office of Water, U.S. Environmental Protection Agency, Washington D.C.

EPA (U.S. Environmental Protection Agency). 2008. Framework for Application of the Toxicity Equivalence Methodology for Polychlorinated Dioxins, Furans, and Biphenyls in Ecological Risk Assessment. (EPA/100/R-08/004).

Frame, G.M., J. W. Cochran, and S.S. Boewadt. 1996. Complete PCB congener distributions for 17 Aroclor mixtures determined by 3 HRGC systems optimized for comprehensive, quantitative, congenerspecific analysis. J. High Resol. Chromatogr., 19:657-668.

Hickey, J.P., S.A. Batterman, and S.M. Chernyak. 2006. Trends of Chlorinated Organic Contaminants in Great Lakes Trout and Walleye from 1970 to 1998. Arch. Environ. Contam. Toxicol. 50:97-110.

Huckins, J.N., M.U. Tubergen, and G.K. Manuweera. 1990. Semipermeable Membrane Devices containing a model lipid: a new approach to monitoring the bioavailability of lipophilic contaminants and estimating their bioconcentration potential. Chemosphere 20(5), 533-552.

McCarthy, J. F., G.R. Southworth, K.D.Ham, and J.A. Palmer. 2000. Time Integrated, Flux-based Monitoring Using Semipermeable Membrane Devices to Estimate the Contribution of Industrial Facilities to Regional Polychlorinated Biphenyl Budgets. Envtl. Toxicol. Chem. 19:352 - 359.

McGrath, K. E., 1988a. Contaminant levels in Missouri Fish - 1985. Missouri Department of Conservation, Jefferson City, Mo.

McGrath, K. E., 1988b. Contaminant levels in Missouri Fish - 1986. Missouri Department of Conservation, Jefferson City, Mo.

Missouri Dept. of Conservation. 2001. Four Phased Total Maximum Daily Loads (TMDLs) for the Blue River, Pollutant: Chlordane. http://www.epa.gov/region7/water/pdf/BlueRiverFinalTMDL.pdf

Papp, Z., G. R. Bortolotti, M. Sebastian, and J. E. G. Smits. 2007. PCB congener profiles in nestling tree swallows and their insect prey. Archives of Environmental Contamination and Toxicology 52: 257-263.

Peterson, M. J., G. R. Southworth, and K. D. Ham. 1994. Effect of sublethal chlorinated discharges on PCB accumulation in transplanted Asiatic clams (Corbicula fluminea). Water, Air, and Soil Pollution 73:169-178.

Pitchford, G.D., R.D. Pulliam, K.P. Sullivan and P.J. Jeffries. 1999. Blue River Watershed Inventory and Assessment. Kansas City Regional Fisheries Office, Missouri Department of Conservation, Blue Springs, Missouri. 
Southworth, G.R., G.F. Cada, L.A. Kszos, M.J. Peterson, E.M. Schilling, J.G. Smith, A.J. Stewart, and R. L. Hinzman. 1997. Monitoring ecological recovery in a stream impacted by contaminated groundwater. Proceedings, 70th Annual Conference of Water Environment Federation.

Southworth, G.R., A.J. Stewart, M.J. Peterson, and T.L. Ashwood. 1992. Bioaccumulation Monitoring and Toxicity Testing in Streams and Groundwater Wells at the U.S. Department of Energy Kansas City Plant. ORNL/TM-11932. Oak Ridge National laboratory, Oak Ridge, Tennessee.

USGS (United States Geological Survey). 2003. Organochlorine Pesticides and PCBs in Bed Sediment and Whole Fish from United States Rivers and Streams: Summary Statistics; Preliminary Results from Cycle I of the National Water Quality Assessment Program (NAWQA), 1992-2001.

http://ca.water.usgs.gov/pnsp/oc doc.html.

Van Den Berg et al. 2006. The 2005 World Health Organization Reevaluation of Human and Mammalian Toxic Equivalency Factors for Dioxins and Dioxin-Like Compounds. Toxicological Sciences. 93(2):223241.

Van den Brink, P. J., N. W. Van den Brink, and C. J. F. Ter Braak. 2003. Multivariate analysis of ecotoxicological data using ordination: demonstrations of utility on the basis of various examples. Australasian Journal of Ecotoxicology 9:141-156.

Wilkison, D.H., Armstrong, D.J., Norman, R.D., Poulton, B.C., Furlong, E.T., and Zaugg, S.D., 2006. Water Quality in the Blue River Basin, Kansas City Metropolitan Area, Missouri and Kansas, July 1998 to October 2004: U.S. Geological Survey Scientific Investigations Report 2006-5147, 170 p.

World Health Organization. 1997. WHO toxic equivalency factors for dioxin-like compounds for humans and wildlife, June 15-18, Stockholm, Sweden. 

APPENDIX A

SAMPLE DATA 

Table A-1. 2007 Kansas City Plant fish collections

\begin{tabular}{|c|c|c|c|c|c|c|c|c|c|c|c|}
\hline \multirow{2}{*}{ Date } & \multirow{2}{*}{ Sex } & \multirow{2}{*}{ Tag } & \multirow{2}{*}{ Length } & \multirow{2}{*}{ Weight } & \multirow{2}{*}{ Smp_mth } & \multirow{2}{*}{ Sampleid } & \multirow{2}{*}{ Tiss_cod } & \multirow{2}{*}{ Type } & \multicolumn{2}{|c|}{ PCB Method } & \multirow{2}{*}{ Archive } \\
\hline & & & & & & & & & Aroclor & Congener & \\
\hline \multicolumn{12}{|c|}{ GREEN SUNFISH - BLK25 } \\
\hline $6 / 5 / 07$ & M & 13171 & 10.1 & 20.0 & & 13171 & MUSC & REG & $\mathrm{X}$ & $\mathrm{X}$ & \\
\hline $6 / 6 / 07$ & M & 13172 & 11.6 & 32.9 & & 13172 & MUSC & REG & $\mathrm{X}$ & $\mathrm{X}$ & \\
\hline $6 / 6 / 07$ & $\mathrm{~F}$ & 13173 & 11.2 & 31.1 & & 13173 & MUSC & REG & $\mathrm{X}$ & $\mathrm{X}$ & \\
\hline $6 / 6 / 07$ & M & 13174 & 10.8 & 23.8 & & 13174 & MUSC & REG & $\mathrm{X}$ & $\mathrm{X}$ & \\
\hline $6 / 6 / 07$ & $\mathrm{~F}$ & 13175 & 9.5 & 18.3 & & 13175 & MUSC & REG & $\mathrm{X}$ & $\mathrm{X}$ & \\
\hline $6 / 6 / 07$ & M & 13176 & 8.3 & 11.6 & & 13176 & MUSC & REG & $\mathrm{X}$ & $\mathrm{X}$ & \\
\hline $6 / 6 / 07$ & $\mathrm{~F}$ & 13177 & 15.1 & 96.4 & & 13177 & MUSC & REG & $\mathrm{X}$ & $X$ & \\
\hline \multirow[t]{2}{*}{$6 / 6 / 07$} & M & 13178 & 12.0 & 43.8 & & 13178 & MUSC & REG & $\mathrm{X}$ & $\mathrm{X}$ & \\
\hline & & Mean: & 11.1 & 34.7 & & & & & & & \\
\hline \multicolumn{12}{|c|}{ GREEN SUNFISH - BLK27 } \\
\hline $6 / 6 / 07$ & M & 13240 & 11.7 & 36.2 & & 13240 & MUSC & REG & $\mathrm{X}$ & $\mathrm{X}$ & \\
\hline $6 / 6 / 07$ & M & 13241 & 13.0 & 47.5 & & 13241 & MUSC & REG & $\mathrm{X}$ & $\mathrm{X}$ & \\
\hline $6 / 6 / 07$ & $\mathrm{~F}$ & 13242 & 12.5 & 48.1 & & 13242 & MUSC & REG & $\mathrm{X}$ & $\mathrm{X}$ & \\
\hline $6 / 6 / 07$ & $\mathrm{~F}$ & 13243 & 11.4 & 30.2 & & 13243 & MUSC & REG & $\mathrm{X}$ & $\mathrm{X}$ & \\
\hline $6 / 6 / 07$ & M & 13244 & 10.2 & 25.2 & & 13244 & MUSC & REG & $\mathrm{X}$ & $\mathrm{X}$ & \\
\hline $6 / 6 / 07$ & M & 13245 & 12.6 & 40.6 & & 13245 & MUSC & REG & $\mathrm{X}$ & $\mathrm{X}$ & \\
\hline $6 / 6 / 07$ & $\mathrm{~F}$ & 13246 & 10.9 & 27.8 & & 13246 & MUSC & REG & $X$ & $X$ & \\
\hline $6 / 6 / 07$ & M & 13247 & 13.8 & 65.7 & & 13247 & MUSC & REG & $\mathrm{X}$ & $X$ & \\
\hline \multirow[t]{2}{*}{$6 / 6 / 07$} & $\mathrm{M}$ & 13247 & & & SPLT & 13248 & MUSC & REP & $X$ & $X$ & \\
\hline & & Mean: & 12.0 & 40.2 & & & & & & & \\
\hline
\end{tabular}


Table A-1. (cont'd)

\begin{tabular}{|c|c|c|c|c|c|c|c|c|c|c|c|}
\hline \multirow{2}{*}{ Date } & \multirow{2}{*}{ Sex } & \multirow{2}{*}{ Tag } & \multirow{2}{*}{ Length } & \multirow{2}{*}{ Weight } & \multirow{2}{*}{ Smp_mth } & \multirow{2}{*}{ Sampleid } & \multirow{2}{*}{ Tiss_cod } & \multirow{2}{*}{ Type } & \multicolumn{2}{|c|}{ PCB Method } & \multirow{2}{*}{ Archive } \\
\hline & & & & & & & & & Aroclor & Congener & \\
\hline \multicolumn{12}{|c|}{ GREEN SUNFISH - BLK31 } \\
\hline $6 / 6 / 07$ & $\mathrm{~F}$ & 13280 & 13.9 & 54.5 & & 13280 & MUSC & REG & $\mathrm{X}$ & $\mathrm{X}$ & \\
\hline $6 / 6 / 07$ & $\mathrm{M}$ & 13281 & 11.4 & 32.1 & & 13281 & MUSC & REG & $\mathrm{X}$ & $\mathrm{X}$ & \\
\hline $6 / 6 / 07$ & $\mathrm{~F}$ & 13282 & 9.9 & 17.8 & & 13282 & MUSC & REG & $\mathrm{X}$ & $\mathrm{X}$ & \\
\hline $6 / 6 / 07$ & $\mathrm{~F}$ & 13283 & 9.4 & 20.6 & & 13283 & MUSC & REG & $\mathrm{X}$ & $\mathrm{X}$ & \\
\hline $6 / 6 / 07$ & $\mathrm{M}$ & 13284 & 10.8 & 26.9 & & 13284 & MUSC & REG & $\mathrm{X}$ & $\mathrm{X}$ & \\
\hline $6 / 6 / 07$ & $\mathrm{~F}$ & 13285 & 9.7 & 16.1 & & 13285 & MUSC & REG & $\mathrm{X}$ & $\mathrm{X}$ & \\
\hline $6 / 6 / 07$ & $\mathrm{~F}$ & 13286 & 9.6 & 15.7 & & 13286 & MUSC & REG & $\mathrm{X}$ & $\mathrm{X}$ & \\
\hline $6 / 6 / 07$ & $\mathrm{M}$ & 13287 & 15.8 & 83.8 & & 13287 & MUSC & REG & $\mathrm{X}$ & $\mathrm{X}$ & \\
\hline \multirow[t]{2}{*}{ 6/6/07 } & $\mathrm{M}$ & 13287 & & & SPLT & 13288 & MUSC & REP & $\mathrm{X}$ & $\mathrm{X}$ & \\
\hline & & Mean: & 11.3 & 33.4 & & & & & & & \\
\hline \multicolumn{12}{|c|}{ GREEN SUNFISH - ICK0.2 } \\
\hline $6 / 5 / 07$ & $\mathrm{~F}$ & 13120 & 11.1 & 29.7 & & 13120 & MUSC & REG & $\mathrm{X}$ & $\mathrm{X}$ & \\
\hline $6 / 5 / 07$ & M & 13121 & 12.8 & 46.6 & & 13121 & MUSC & REG & $\mathrm{X}$ & $\mathrm{X}$ & \\
\hline $6 / 5 / 07$ & M & 13122 & 12.9 & 51.4 & & 13122 & MUSC & REG & $\mathrm{X}$ & $\mathrm{X}$ & \\
\hline $6 / 5 / 07$ & $\mathrm{~F}$ & 13123 & 12.0 & 34.4 & & 13123 & MUSC & REG & $\mathrm{X}$ & $\mathrm{X}$ & \\
\hline $6 / 5 / 07$ & M & 13124 & 12.6 & 38.4 & & 13124 & MUSC & REG & $\mathrm{X}$ & $\mathrm{X}$ & \\
\hline $6 / 5 / 07$ & M & 13125 & 11.9 & 35.1 & & 13125 & MUSC & REG & $\mathrm{X}$ & $\mathrm{X}$ & \\
\hline $6 / 5 / 07$ & $\mathrm{M}$ & 13126 & 11.5 & 33.5 & & 13126 & MUSC & REG & $\mathrm{X}$ & $\mathrm{X}$ & \\
\hline \multirow[t]{2}{*}{$6 / 5 / 07$} & $\mathrm{M}$ & 13127 & 13.8 & 55.4 & & 13127 & MUSC & REG & $\mathrm{X}$ & $\mathrm{X}$ & \\
\hline & & Mean: & 12.3 & 40.6 & & & & & & & \\
\hline
\end{tabular}


Table A-1. (cont'd)

\begin{tabular}{|c|c|c|c|c|c|c|c|c|c|c|c|}
\hline \multirow{2}{*}{ Date } & \multirow{2}{*}{ Sex } & \multirow{2}{*}{ Tag } & \multirow{2}{*}{ Length } & \multirow{2}{*}{ Weight } & \multirow{2}{*}{ Smp_mth } & \multirow{2}{*}{ Sampleid } & \multirow{2}{*}{ Tiss_cod } & \multirow{2}{*}{ Type } & \multicolumn{2}{|c|}{ PCB Method } & \multirow{2}{*}{ Archive } \\
\hline & & & & & & & & & Aroclor & Congener & \\
\hline \multicolumn{12}{|c|}{ GREEN SUNFISH - ICK1.0 } \\
\hline $6 / 5 / 07$ & $\mathrm{~F}$ & 12890 & 11.7 & 31.1 & & 12890 & MUSC & REG & $\mathrm{X}$ & $\mathrm{X}$ & \\
\hline $6 / 5 / 07$ & M & 12891 & 11.5 & 31.1 & & 12891 & MUSC & REG & $\mathrm{X}$ & $\mathrm{X}$ & \\
\hline $6 / 5 / 07$ & $\mathrm{~F}$ & 12892 & 10.6 & 29.7 & & 12892 & MUSC & REG & $\mathrm{X}$ & $\mathrm{X}$ & \\
\hline $6 / 5 / 07$ & $\mathrm{~F}$ & 12893 & 11.5 & 35.5 & & 12893 & MUSC & REG & $\mathrm{X}$ & $\mathrm{X}$ & \\
\hline $6 / 5 / 07$ & M & 12894 & 12.0 & 37.7 & & 12894 & MUSC & REG & $\mathrm{X}$ & $\mathrm{X}$ & \\
\hline $6 / 5 / 07$ & M & 12895 & 12.1 & 36.8 & & 12895 & MUSC & REG & $\mathrm{X}$ & $\mathrm{X}$ & \\
\hline $6 / 5 / 07$ & M & 12896 & 12.5 & 44.7 & & 12896 & MUSC & REG & $\mathrm{X}$ & $\mathrm{X}$ & \\
\hline $6 / 5 / 07$ & M & 12897 & 14.1 & 62.9 & & 12897 & MUSC & REG & $\mathrm{X}$ & $\mathrm{X}$ & \\
\hline \multirow[t]{2}{*}{$6 / 5 / 07$} & M & 12897 & & & SPLT & 12898 & MUSC & REP & $\mathrm{X}$ & $\mathrm{X}$ & \\
\hline & & Mean: & 12.0 & 38.7 & & & & & & & \\
\hline \multicolumn{12}{|c|}{ GREEN SUNFISH - ICK3.0 } \\
\hline $6 / 7 / 07$ & M & 13190 & 13.2 & 55.0 & & 13190 & MUSC & REG & $\mathrm{X}$ & $\mathrm{X}$ & \\
\hline $6 / 7 / 07$ & $\mathrm{~F}$ & 13191 & 12.8 & 42.4 & & 13191 & MUSC & REG & $\mathrm{X}$ & $\mathrm{X}$ & \\
\hline $6 / 7 / 07$ & M & 13192 & 10.5 & 22.4 & & 13192 & MUSC & REG & $\mathrm{X}$ & $\mathrm{X}$ & \\
\hline $6 / 7 / 07$ & $\mathrm{~F}$ & 13194 & 10.6 & 24.5 & & 13194 & MUSC & REG & $\mathrm{X}$ & $\mathrm{X}$ & \\
\hline $6 / 7 / 07$ & M & 13195 & 15.5 & 81.3 & & 13195 & MUSC & REG & $\mathrm{X}$ & $\mathrm{X}$ & \\
\hline $6 / 7 / 07$ & M & 13196 & 13.5 & 53.2 & & 13196 & MUSC & REG & $\mathrm{X}$ & $\mathrm{X}$ & \\
\hline $6 / 7 / 07$ & $\mathrm{~F}$ & 13197 & 10.6 & 23.6 & & 13197 & MUSC & REG & $X$ & $X$ & \\
\hline $6 / 7 / 07$ & $\mathrm{M}$ & 13198 & 15.7 & 91.5 & & 13198 & MUSC & REG & $X$ & $X$ & \\
\hline \multirow[t]{2}{*}{$6 / 7 / 07$} & M & 13198 & & & SPLT & 13199 & MUSC & REP & $X$ & $X$ & \\
\hline & & Mean: & 12.8 & 49.2 & & & & & & & \\
\hline
\end{tabular}


Table A-1. (cont'd)

\begin{tabular}{|c|c|c|c|c|c|c|c|c|c|c|c|}
\hline \multirow{2}{*}{ Date } & \multirow{2}{*}{ Sex } & \multirow{2}{*}{ Tag } & \multirow{2}{*}{ Length } & \multirow{2}{*}{ Weight } & \multirow{2}{*}{ Smp_mth } & \multirow{2}{*}{ Sampleid } & \multirow{2}{*}{ Tiss_cod } & \multirow{2}{*}{ Type } & \multicolumn{2}{|c|}{ PCB Method } & \multirow{2}{*}{ Archive } \\
\hline & & & & & & & & & Aroclor & Congener & \\
\hline \multicolumn{12}{|c|}{ GREEN SUNFISH - BCK0.2 (3- or 4-fish composites) } \\
\hline $6 / 7 / 07$ & & 12967 & 6.5 & 5.2 & $\mathrm{SC}$ & 12967 & MUSC & REG & $\mathrm{X}$ & $\mathrm{X}$ & \\
\hline $6 / 7 / 07$ & & 12968 & 5.8 & 3.6 & $\mathrm{SC}$ & 12968 & MUSC & REG & $\mathrm{X}$ & $\mathrm{X}$ & \\
\hline \multirow[t]{2}{*}{$6 / 7 / 07$} & & 12969 & 5.7 & 3.5 & $\mathrm{SC}$ & 12969 & MUSC & REG & $\mathrm{X}$ & $\mathrm{X}$ & \\
\hline & & Mean: & 6.0 & 4.1 & & & & & & & \\
\hline \multicolumn{12}{|c|}{ CHANNEL CATFISH - BLK25 } \\
\hline $6 / 5 / 07$ & M & 13150 & 39.4 & 560.0 & & 13150 & MUSC & REG & $\mathrm{X}$ & $\mathrm{X}$ & $\mathrm{X}$ \\
\hline $6 / 5 / 07$ & M & 13151 & 46.2 & 956.7 & & 13151 & MUSC & REG & $\mathrm{X}$ & $\mathrm{X}$ & $\mathrm{X}$ \\
\hline $6 / 6 / 07$ & $\mathrm{M}$ & 13152 & 41.1 & 656.7 & & 13152 & MUSC & REG & $X$ & $X$ & $X$ \\
\hline $6 / 6 / 07$ & M & 13153 & 41.1 & 695.0 & & 13153 & MUSC & REG & $X$ & $X$ & $X$ \\
\hline $6 / 6 / 07$ & F & 13154 & 36.8 & 462.7 & & 13154 & MUSC & REG & $X$ & $X$ & $X$ \\
\hline $6 / 6 / 07$ & $\mathrm{M}$ & 13155 & 33.4 & 380.4 & & 13155 & MUSC & REG & $X$ & $\mathrm{X}$ & $\mathrm{X}$ \\
\hline $6 / 6 / 07$ & M & 13156 & 48.1 & 715.0 & & 13156 & MUSC & REG & $X$ & $X$ & $X$ \\
\hline $6 / 6 / 07$ & $\mathrm{M}$ & 13157 & 46.1 & 1067.8 & & 13157 & MUSC & REG & $X$ & $X$ & $X$ \\
\hline \multirow[t]{2}{*}{$6 / 6 / 07$} & M & 13157 & & & SPLT & 13158 & MUSC & REP & $X$ & $X$ & \\
\hline & & Mean: & 41.5 & 686.8 & & & & & & & \\
\hline \multicolumn{12}{|c|}{ CHANNEL CATFISH - BLK27 } \\
\hline $6 / 6 / 07$ & M & 13220 & 38.6 & 572.2 & & 13220 & MUSC & REG & $\mathrm{X}$ & $\mathrm{X}$ & $\mathrm{X}$ \\
\hline $6 / 6 / 07$ & $\mathrm{~F}$ & 13221 & 42.2 & 849.2 & & 13221 & MUSC & REG & $\mathrm{X}$ & $\mathrm{X}$ & $\mathrm{X}$ \\
\hline $6 / 6 / 07$ & M & 13222 & 34.5 & 372.2 & & 13222 & MUSC & REG & $\mathrm{X}$ & $\mathrm{X}$ & $\mathrm{X}$ \\
\hline $6 / 6 / 07$ & M & 13223 & 42.1 & 710.0 & & 13223 & MUSC & REG & $\mathrm{X}$ & $\mathrm{X}$ & $\mathrm{X}$ \\
\hline $6 / 6 / 07$ & $\mathrm{~F}$ & 13224 & 51.0 & 1509.1 & & 13224 & MUSC & REG & $\mathrm{X}$ & $\mathrm{X}$ & $\mathrm{X}$ \\
\hline $6 / 6 / 07$ & M & 13225 & 32.0 & 286.6 & & 13225 & MUSC & REG & $\mathrm{X}$ & $\mathrm{X}$ & $\mathrm{X}$ \\
\hline $6 / 6 / 07$ & F & 13226 & 45.2 & 1078.8 & & 13226 & MUSC & REG & $X$ & $X$ & $\mathrm{X}$ \\
\hline \multirow[t]{2}{*}{$6 / 6 / 07$} & $\mathrm{~F}$ & 13226 & & & SPLT & 13227 & MUSC & REP & $\mathrm{X}$ & $\mathrm{X}$ & \\
\hline & & Mean: & 40.8 & 768.3 & & & & & & & \\
\hline
\end{tabular}


Table A-1. (cont'd)

\begin{tabular}{|c|c|c|c|c|c|c|c|c|c|c|c|}
\hline \multirow{2}{*}{ Date } & \multirow{2}{*}{ Sex } & \multirow{2}{*}{ Tag } & \multirow{2}{*}{ Length } & \multirow{2}{*}{ Weight } & \multirow{2}{*}{ Smp_mth } & \multirow{2}{*}{ Sampleid } & \multirow{2}{*}{ Tiss_cod } & \multirow{2}{*}{ Type } & \multicolumn{2}{|c|}{ PCB Method } & \multirow{2}{*}{ Archive } \\
\hline & & & & & & & & & Aroclor & Congener & \\
\hline \multicolumn{12}{|c|}{ CHANNEL CATFISH - BLK31 } \\
\hline $6 / 6 / 07$ & $\mathrm{M}$ & 13250 & 40.2 & 665.2 & & 13250 & MUSC & REG & $\mathrm{X}$ & $\mathrm{X}$ & $\mathrm{X}$ \\
\hline $6 / 6 / 07$ & M & 13251 & 33.2 & 342.3 & & 13251 & MUSC & REG & $\mathrm{X}$ & $\mathrm{X}$ & $\mathrm{X}$ \\
\hline $6 / 6 / 07$ & M & 13252 & 36.5 & 502.0 & & 13252 & MUSC & REG & $\mathrm{X}$ & $\mathrm{X}$ & $\mathrm{X}$ \\
\hline $6 / 6 / 07$ & F & 13253 & 37.1 & 575.9 & & 13253 & MUSC & REG & $\mathrm{X}$ & $\mathrm{X}$ & $\mathrm{X}$ \\
\hline $6 / 6 / 07$ & $\mathrm{M}$ & 13254 & 36.0 & 430.0 & & 13254 & MUSC & REG & $\mathrm{X}$ & $\mathrm{X}$ & $\mathrm{X}$ \\
\hline $6 / 6 / 07$ & F & 13255 & 41.0 & 737.1 & & 13255 & MUSC & REG & $\mathrm{X}$ & $\mathrm{X}$ & $\mathrm{X}$ \\
\hline $6 / 6 / 07$ & M & 13256 & 46.7 & 983.7 & & 13256 & MUSC & REG & $\mathrm{X}$ & $\mathrm{X}$ & $\mathrm{X}$ \\
\hline $6 / 6 / 07$ & $\mathrm{M}$ & 13257 & 48.0 & 1059.4 & & 13257 & MUSC & REG & $\mathrm{X}$ & $\mathrm{X}$ & $\mathrm{X}$ \\
\hline \multirow[t]{2}{*}{$6 / 6 / 07$} & $\mathrm{M}$ & 13257 & & & SPLT & 13258 & MUSC & REP & $\mathrm{X}$ & $\mathrm{X}$ & \\
\hline & & Mean: & 39.8 & 662.0 & & & & & & & \\
\hline \multicolumn{12}{|c|}{ CHANNEL CATFISH - ICK0.2 } \\
\hline $6 / 5 / 07$ & $\mathrm{M}$ & 13110 & 56.9 & 1892.7 & & 13110 & MUSC & REG & $\mathrm{X}$ & $\mathrm{X}$ & $\mathrm{X}$ \\
\hline $6 / 5 / 07$ & $\mathrm{M}$ & 13111 & 43.8 & 711.9 & & 13111 & MUSC & REG & $\mathrm{X}$ & $\mathrm{X}$ & $\mathrm{X}$ \\
\hline $6 / 5 / 07$ & M & 13112 & 45.3 & 827.3 & & 13112 & MUSC & REG & $\mathrm{X}$ & $\mathrm{X}$ & $\mathrm{X}$ \\
\hline $6 / 5 / 07$ & $\mathrm{~F}$ & 13113 & 42.2 & 710.7 & & 13113 & MUSC & REG & $\mathrm{X}$ & $\mathrm{X}$ & $\mathrm{X}$ \\
\hline $6 / 5 / 07$ & M & 13114 & 41.2 & 548.8 & & 13114 & MUSC & REG & $\mathrm{X}$ & $\mathrm{X}$ & $\mathrm{X}$ \\
\hline $6 / 5 / 07$ & $\mathrm{~F}$ & 13115 & 45.1 & 808.0 & & 13115 & MUSC & REG & $\mathrm{X}$ & $\mathrm{X}$ & $\mathrm{X}$ \\
\hline $6 / 5 / 07$ & M & 13116 & 41.7 & 627.8 & & 13116 & MUSC & REG & $X$ & $X$ & $\mathrm{X}$ \\
\hline $6 / 5 / 07$ & $\mathrm{M}$ & 13117 & 33.3 & 326.3 & & 13117 & MUSC & REG & $X$ & $X$ & $X$ \\
\hline \multirow[t]{2}{*}{$6 / 5 / 07$} & $\mathrm{M}$ & 13117 & & & SPLT & 13118 & MUSC & REP & $\mathrm{X}$ & $\mathrm{X}$ & \\
\hline & & Mean: & 43.7 & 806.7 & & & & & & & \\
\hline
\end{tabular}


Table A-1. (cont'd)

\begin{tabular}{|c|c|c|c|c|c|c|c|c|c|c|c|}
\hline \multirow{2}{*}{ Date } & \multirow{2}{*}{ Sex } & \multirow{2}{*}{ Tag } & \multirow{2}{*}{ Length } & \multirow{2}{*}{ Weight } & \multirow{2}{*}{ Smp_mth } & \multirow{2}{*}{ Sampleid } & \multirow{2}{*}{ Tiss_cod } & \multirow{2}{*}{ Type } & \multicolumn{2}{|c|}{ PCB Method } & \multirow{2}{*}{ Archive } \\
\hline & & & & & & & & & Aroclor & Congener & \\
\hline \multicolumn{12}{|c|}{ CHANNEL CATFISH - ICK1.0 } \\
\hline $6 / 5 / 07$ & M & 13210 & 35.8 & 462.3 & & 13210 & MUSC & REG & $\mathrm{X}$ & $\mathrm{X}$ & $\mathrm{X}$ \\
\hline $6 / 5 / 07$ & M & 13211 & 45.0 & 818.0 & & 13211 & MUSC & REG & $\mathrm{X}$ & $\mathrm{X}$ & $X$ \\
\hline $6 / 5 / 07$ & M & 13212 & 39.3 & 624.5 & & 13212 & MUSC & REG & $\mathrm{X}$ & $\mathrm{X}$ & $\mathrm{X}$ \\
\hline $6 / 5 / 07$ & $\mathrm{~F}$ & 13213 & 45.4 & 1046.3 & & 13213 & MUSC & REG & $\mathrm{X}$ & $\mathrm{X}$ & $\mathrm{X}$ \\
\hline $6 / 5 / 07$ & $\mathrm{M}$ & 13214 & 51.0 & 1220.2 & & 13214 & MUSC & REG & $\mathrm{X}$ & $\mathrm{X}$ & $\mathrm{X}$ \\
\hline $6 / 5 / 07$ & F & 13215 & 47.0 & 1112.2 & & 13215 & MUSC & REG & $\mathrm{X}$ & $\mathrm{X}$ & $\mathrm{X}$ \\
\hline $6 / 5 / 07$ & M & 13216 & 50.2 & 1153.5 & & 13216 & MUSC & REG & $\mathrm{X}$ & $\mathrm{X}$ & $\mathrm{X}$ \\
\hline $6 / 5 / 07$ & F & 13217 & 55.7 & 1641.3 & & 13217 & MUSC & REG & $\mathrm{X}$ & $\mathrm{X}$ & $\mathrm{X}$ \\
\hline \multirow[t]{2}{*}{$6 / 5 / 07$} & $\mathrm{~F}$ & 13217 & & & SPLT & 13218 & MUSC & REP & $\mathrm{X}$ & $\mathrm{X}$ & \\
\hline & & Mean: & 46.2 & 1009.8 & & & & & & & \\
\hline \multicolumn{12}{|c|}{ CHANNEL CATFISH - ICK3.0 } \\
\hline $6 / 7 / 07$ & M & 13270 & 40.2 & 586.5 & & 13270 & MUSC & REG & $\mathrm{X}$ & $\mathrm{X}$ & $\mathrm{X}$ \\
\hline $6 / 7 / 07$ & M & 13271 & 32.8 & 352.8 & & 13271 & MUSC & REG & $\mathrm{X}$ & $\mathrm{X}$ & $\mathrm{X}$ \\
\hline $6 / 7 / 07$ & M & 13272 & 37.2 & 470.6 & & 13272 & MUSC & REG & $\mathrm{X}$ & $\mathrm{X}$ & $\mathrm{X}$ \\
\hline $6 / 7 / 07$ & M & 13273 & 38.5 & 546.5 & & 13273 & MUSC & REG & $\mathrm{X}$ & $\mathrm{X}$ & $\mathrm{X}$ \\
\hline $6 / 7 / 07$ & M & 13274 & 37.1 & 510.2 & & 13274 & MUSC & REG & $\mathrm{X}$ & $\mathrm{X}$ & $\mathrm{X}$ \\
\hline $6 / 7 / 07$ & M & 13275 & 42.5 & 762.4 & & 13275 & MUSC & REG & $\mathrm{X}$ & $\mathrm{X}$ & $\mathrm{X}$ \\
\hline $6 / 7 / 07$ & M & 13276 & 45.0 & 971.4 & & 13276 & MUSC & REG & $X$ & $X$ & $\mathrm{X}$ \\
\hline $6 / 7 / 07$ & F & 13277 & 48.5 & 1267.2 & & 13277 & MUSC & REG & $X$ & $X$ & $X$ \\
\hline \multirow[t]{2}{*}{$6 / 7 / 07$} & F & 13277 & & & SPLT & 13278 & MUSC & REP & $\mathrm{X}$ & $\mathrm{X}$ & \\
\hline & & Mean: & 40.2 & 683.5 & & & & & & & \\
\hline
\end{tabular}


Table A-2. Field data, Aroclor-specific PCB concentrations (ng/g, wet wt), and \% lipid content, in individual green sunfish and channel catfish fillet collected from sites on Indian Creek (ICK), Blue River (BLK), and Boone Creek (BCK) near the Kansas City Plant, June 2007

\begin{tabular}{|c|c|c|c|c|c|c|c|c|c|c|}
\hline Site & $\begin{array}{c}\text { Collection } \\
\text { date }\end{array}$ & Species & Sex & $\begin{array}{c}\text { Length } \\
(\mathrm{cm})\end{array}$ & $\begin{array}{c}\text { Weight } \\
\text { (g) }\end{array}$ & $\begin{array}{l}\text { Sample } \\
\text { number }\end{array}$ & $\begin{array}{c}\text { Aroclor } \\
1248 \\
\end{array}$ & $\begin{array}{c}\text { Aroclor } \\
1254 \\
\end{array}$ & $\begin{array}{c}\text { Aroclor } \\
1260 \\
\end{array}$ & \% Lipids \\
\hline BLK25 & $6 / 5 / 07$ & GREENS & $\mathrm{M}$ & 10.1 & 20.0 & 13171 & 65 & 40 & $24 \mathrm{iu}$ & 1.8 \\
\hline BLK25 & $6 / 6 / 07$ & GREENS & $\mathrm{M}$ & 11.6 & 32.9 & 13172 & 36 & 19 & $<14 \mathrm{iu}$ & nd \\
\hline BLK25 & $6 / 6 / 07$ & GREENS & $\mathrm{F}$ & 11.2 & 31.1 & 13173 & 62 & 43 & $<16 \mathrm{iu}$ & 1.4 \\
\hline BLK25 & $6 / 6 / 07$ & GREENS & $\mathrm{M}$ & 10.8 & 23.8 & 13174 & 43 & 32 & $<21 \mathrm{iu}$ & 1.1 \\
\hline BLK25 & $6 / 6 / 07$ & GREENS & $\mathrm{F}$ & 9.5 & 18.3 & 13175 & 90 & 44 & $<33 \mathrm{iu}$ & 1.3 \\
\hline BLK25 & $6 / 6 / 07$ & GREENS & $\mathrm{M}$ & 8.3 & 11.6 & 13176 & 95 & 42 & $<42 \mathrm{iu}$ & 1.6 \\
\hline BLK25 & $6 / 6 / 07$ & GREENS & $\mathrm{F}$ & 15.1 & 96.4 & 13177 & 83 & 48 & $<20 \mathrm{iu}$ & 1.8 \\
\hline BLK25 & $6 / 6 / 07$ & GREENS & $\mathrm{M}$ & 12.0 & 43.8 & 13178 & 95 & 59 & $<28 \mathrm{iu}$ & 1.1 \\
\hline BLK27 & $6 / 6 / 07$ & GREENS & $\mathrm{M}$ & 11.7 & 36.2 & 13240 & 33 & 39 & 15 & 1.1 \\
\hline BLK27 & $6 / 6 / 07$ & GREENS & $\mathrm{M}$ & 13.0 & 47.5 & 13241 & 22 & 31 & $<15 \mathrm{iu}$ & nd \\
\hline BLK27 & $6 / 6 / 07$ & GREENS & $\mathrm{F}$ & 12.5 & 48.1 & 13242 & 16 & 34 & 14 & nd \\
\hline BLK27 & $6 / 6 / 07$ & GREENS & $\mathrm{F}$ & 11.4 & 30.2 & 13243 & 120 & 67 & $<32 \mathrm{iu}$ & 1.3 \\
\hline BLK27 & $6 / 6 / 07$ & GREENS & $\mathrm{M}$ & 10.2 & 25.2 & 13244 & 44 & 24 & $<20 \mathrm{iu}$ & nd \\
\hline BLK27 & $6 / 6 / 07$ & GREENS & $\mathrm{M}$ & 12.6 & 40.6 & 13245 & 28 & 24 & $<10 \mathrm{iu}$ & nd \\
\hline BLK27 & $6 / 6 / 07$ & GREENS & $\mathrm{F}$ & 10.9 & 27.8 & 13246 & 76 & 84 & $<39 \mathrm{iu}$ & 1.1 \\
\hline BLK27 & $6 / 6 / 07$ & GREENS & $\mathrm{M}$ & 13.8 & 65.7 & 13247 & 84 & 85 & $<31 \mathrm{iu}$ & 2.9 \\
\hline BLK31 & $6 / 6 / 07$ & GREENS & $\mathrm{F}$ & 13.9 & 54.5 & 13280 & $<7 \mathrm{iu}$ & $4 \mathrm{j}$ ap & $<7 \mathrm{iu}$ & nd \\
\hline BLK31 & $6 / 6 / 07$ & GREENS & $\mathrm{M}$ & 11.4 & 32.1 & 13281 & $<14 \mathrm{iu}$ & $7 \mathrm{j}$ ap & $<14 \mathrm{iu}$ & nd \\
\hline BLK31 & $6 / 6 / 07$ & GREENS & $\mathrm{F}$ & 9.9 & 17.8 & 13282 & $14 \mathrm{j}$ ap & $9 \mathrm{j}$ ap & $<29 \mathrm{iu}$ & nd \\
\hline BLK31 & $6 / 6 / 07$ & GREENS & $\mathrm{F}$ & 9.4 & 20.6 & 13283 & $<110 \mathrm{iu}$ & $<110 \mathrm{iu}$ & $<110 \mathrm{iu}$ & 1.2 \\
\hline BLK31 & $6 / 6 / 07$ & GREENS & $\mathrm{M}$ & 10.8 & 26.9 & 13284 & $7 \mathrm{j}$ ap & $8 \mathrm{j}$ ap & $<14 \mathrm{iu}$ & 1.2 \\
\hline BLK31 & $6 / 6 / 07$ & GREENS & $\mathrm{F}$ & 9.7 & 16.1 & 13285 & $<37 \mathrm{u}$ & $<37 \mathrm{iu}$ & $<37 \mathrm{u}$ & nd \\
\hline BLK31 & $6 / 6 / 07$ & GREENS & $\mathrm{F}$ & 9.6 & 15.7 & 13286 & $<40 \mathrm{u}$ & $<40 \mathrm{iu}$ & $<40 \mathrm{u}$ & nd \\
\hline BLK31 & $6 / 6 / 07$ & GREENS & $\mathrm{M}$ & 15.8 & 83.8 & 13287 & $2 \mathrm{j}$ ap & $<11 \mathrm{iu}$ & $<11 \mathrm{iu}$ & nd \\
\hline ICK 0.2 & $6 / 5 / 07$ & GREENS & $\mathrm{F}$ & 11.1 & 29.7 & 13120 & 59 & 31 & $<17 \mathrm{iu}$ & 1.2 \\
\hline ICK 0.2 & $6 / 5 / 07$ & GREENS & $\mathrm{M}$ & 12.8 & 46.6 & 13121 & 540 & 130 & $<110 \mathrm{iu}$ & 1.4 \\
\hline ICK 0.2 & $6 / 5 / 07$ & GREENS & $\mathrm{M}$ & 12.9 & 51.4 & 13122 & 52 & 42 & $<17 \mathrm{iu}$ & 1.3 \\
\hline ICK 0.2 & $6 / 5 / 07$ & GREENS & $\mathrm{F}$ & 12.0 & 34.4 & 13123 & 24 & 15 & $<14 \mathrm{iu}$ & nd \\
\hline ICK 0.2 & $6 / 5 / 07$ & GREENS & $\mathrm{M}$ & 12.6 & 38.4 & 13124 & 12 & 14 & $<11 \mathrm{iu}$ & nd \\
\hline ICK 0.2 & $6 / 5 / 07$ & GREENS & $\mathrm{M}$ & 11.9 & 35.1 & 13125 & 190 & 46 & $<33 \mathrm{iu}$ & 1 \\
\hline ICK 0.2 & $6 / 5 / 07$ & GREENS & $\mathrm{M}$ & 11.5 & 33.5 & 13126 & 58 & 26 & $<14 \mathrm{iu}$ & nd \\
\hline ICK 0.2 & $6 / 5 / 07$ & GREENS & $\mathrm{M}$ & 13.8 & 55.4 & 13127 & 42 & 19 & $<18 \mathrm{iu}$ & 1.2 \\
\hline
\end{tabular}


Table A-2. (cont'd)

\begin{tabular}{|c|c|c|c|c|c|c|c|c|c|c|}
\hline Site & $\begin{array}{c}\text { Collection } \\
\text { date }\end{array}$ & Species & Sex & $\begin{array}{c}\text { Length } \\
(\mathrm{cm})\end{array}$ & $\begin{array}{c}\text { Weight } \\
\text { (g) }\end{array}$ & $\begin{array}{l}\text { Sample } \\
\text { number }\end{array}$ & $\begin{array}{c}\text { Aroclor } \\
1248 \\
\end{array}$ & $\begin{array}{c}\text { Aroclor } \\
1254 \\
\end{array}$ & $\begin{array}{c}\text { Aroclor } \\
1260 \\
\end{array}$ & \% Lipids \\
\hline ICK 1.0 & $6 / 5 / 07$ & GREENS & $\mathrm{F}$ & 11.7 & 31.1 & 12890 & 83 & 38 & $<16 \mathrm{iu}$ & 1.1 \\
\hline ICK 1.0 & $6 / 5 / 07$ & GREENS & M & 11.5 & 31.1 & 12891 & $16 \mathrm{iu}$ & 18 & $<16 \mathrm{iu}$ & 1.4 \\
\hline ICK 1.0 & $6 / 5 / 07$ & GREENS & $\mathrm{F}$ & 10.6 & 29.7 & 12892 & 60 & 33 & $<16 \mathrm{iu}$ & 1.6 \\
\hline ICK 1.0 & $6 / 5 / 07$ & GREENS & $\mathrm{F}$ & 11.5 & 35.5 & 12893 & 120 & 51 & $<28 \mathrm{iu}$ & 1.5 \\
\hline ICK 1.0 & $6 / 5 / 07$ & GREENS & M & 12.0 & 37.7 & 12894 & 48 & 29 & $<11 \mathrm{iu}$ & nd \\
\hline ICK 1.0 & $6 / 5 / 07$ & GREENS & M & 12.1 & 36.8 & 12895 & $<11 \mathrm{iu}$ & $9 \mathrm{j}$ ap & $<11 \mathrm{iu}$ & nd \\
\hline ICK1.0 & $6 / 5 / 07$ & GREENS & M & 12.5 & 44.7 & 12896 & 30 & 21 & $<11 \mathrm{iu}$ & nd \\
\hline ICK1.0 & $6 / 5 / 07$ & GREENS & $\mathrm{M}$ & 14.1 & 62.9 & 12897 & $<14 \mathrm{iu}$ & $9 \mathrm{j}$ ap & $<14 \mathrm{iu}$ & nd \\
\hline ICK3.0 & $6 / 7 / 07$ & GREENS & $\mathrm{M}$ & 13.2 & 55.0 & 13190 & $<17 \mathrm{iu}$ & $9 \mathrm{j}$ ap & $<17 \mathrm{iu}$ & 1.3 \\
\hline ICK 3.0 & $6 / 7 / 07$ & GREENS & $\mathrm{F}$ & 12.8 & 42.4 & 13191 & $<20 \mathrm{iu}$ & $8 \mathrm{j}$ ap & $<20 \mathrm{iu}$ & 1 \\
\hline ICK3.0 & $6 / 7 / 07$ & GREENS & M & 10.5 & 22.4 & 13192 & $<24 \mathrm{iu}$ & $6 \mathrm{j}$ ap & $<24 \mathrm{iu}$ & 1 \\
\hline ICK3.0 & $6 / 7 / 07$ & GREENS & $\mathrm{F}$ & 10.6 & 24.5 & 13194 & $<18 \mathrm{iu}$ & $7 \mathrm{j}$ ap & $<18 \mathrm{iu}$ & 1.1 \\
\hline ICK 3.0 & $6 / 7 / 07$ & GREENS & M & 15.5 & 81.3 & 13195 & $<16 \mathrm{iu}$ & 25 & $11 \mathrm{j}$ ap & 1.6 \\
\hline ICK 3.0 & $6 / 7 / 07$ & GREENS & M & 13.5 & 53.2 & 13196 & $<16 \mathrm{iu}$ & $6 \mathrm{j}$ ap & $<16 \mathrm{iu}$ & 1.1 \\
\hline ICK3.0 & $6 / 7 / 07$ & GREENS & $\mathrm{F}$ & 10.6 & 23.6 & 13197 & $<22$ iu & $7 \mathrm{j}$ ap & $<22 \mathrm{iu}$ & nd \\
\hline ICK3.0 & $6 / 7 / 07$ & GREENS & $\mathrm{M}$ & 15.7 & 91.5 & 13198 & $5 \mathrm{j}$ ap & $7 \mathrm{j}$ ap & $<11 \mathrm{iu}$ & nd \\
\hline BCK0.2 & $6 / 7 / 07$ & GREENS & NA & 6.5 & 5.2 & 12967 & 140 & 76 & $<38 \mathrm{iu}$ & 1.6 \\
\hline BCK0.2 & $6 / 7 / 07$ & GREENS & NA & 5.8 & 3.6 & 12968 & 310 & 280 & $<140 \mathrm{iu}$ & 1.7 \\
\hline BCK0.2 & $6 / 7 / 07$ & GREENS & NA & 5.7 & 3.5 & 12969 & 190 & 100 & $<58 \mathrm{iu}$ & 1.9 \\
\hline BLK25 & $6 / 5 / 07$ & CHNCAT & $\mathrm{M}$ & 39.4 & 560.0 & 13150 & 180 & 140 & 56 & 6.4 \\
\hline BLK25 & $6 / 5 / 07$ & CHNCAT & M & 46.2 & 956.7 & 13151 & 300 & 250 & $<110 \mathrm{iu}$ & 5.6 \\
\hline BLK25 & $6 / 6 / 07$ & CHNCAT & M & 41.1 & 656.7 & 13152 & 300 & 240 & $<110 \mathrm{iu}$ & 5.6 \\
\hline BLK25 & $6 / 6 / 07$ & CHNCAT & M & 41.1 & 695.0 & 13153 & 200 & 150 & 61 & 4.6 \\
\hline BLK25 & $6 / 6 / 07$ & CHNCAT & $\mathrm{F}$ & 36.8 & 462.7 & 13154 & 200 & 180 & 70 & 5.4 \\
\hline BLK25 & $6 / 6 / 07$ & CHNCAT & M & 33.4 & 380.4 & 13155 & 170 & 120 & 44 & 4.1 \\
\hline BLK25 & $6 / 6 / 07$ & CHNCAT & M & 48.1 & 715.0 & 13156 & 14 & $9 \mathrm{j}$ ap & $8 \mathrm{j}$ ap & nd \\
\hline BLK25 & $6 / 6 / 07$ & CHNCAT & $\mathrm{M}$ & 46.1 & 1067.8 & 13157 & 260 & 190 & 120 & 2.7 \\
\hline BLK27 & $6 / 6 / 07$ & CHNCAT & $\mathrm{M}$ & 38.6 & 572.2 & 13220 & 440 & 290 & 110 & 7.1 \\
\hline BLK27 & $6 / 6 / 07$ & CHNCAT & $\mathrm{F}$ & 42.2 & 849.2 & 13221 & 170 & 170 & 69 & 4.6 \\
\hline BLK27 & $6 / 6 / 07$ & CHNCAT & M & 34.5 & 372.2 & 13222 & 110 & 130 & 48 & 3.7 \\
\hline BLK27 & $6 / 6 / 07$ & CHNCAT & M & 42.1 & 710.0 & 13223 & 100 & 140 & 63 & 4.1 \\
\hline BLK27 & $6 / 6 / 07$ & CHNCAT & $\mathrm{F}$ & 51.0 & 1509.1 & 13224 & 150 & 160 & 64 & 5.5 \\
\hline BLK27 & $6 / 6 / 07$ & CHNCAT & M & 32.0 & 286.6 & 13225 & 110 & 120 & 45 & 4 \\
\hline
\end{tabular}


Table A-2. (cont'd)

\begin{tabular}{|c|c|c|c|c|c|c|c|c|c|c|}
\hline Site & $\begin{array}{c}\text { Collection } \\
\text { date }\end{array}$ & Species & Sex & $\begin{array}{c}\text { Length } \\
\text { (cm) }\end{array}$ & $\begin{array}{c}\text { Weight } \\
\text { (g) }\end{array}$ & $\begin{array}{l}\text { Sample } \\
\text { number }\end{array}$ & $\begin{array}{c}\text { Aroclor } \\
1248 \\
\end{array}$ & $\begin{array}{c}\text { Aroclor } \\
1254 \\
\end{array}$ & $\begin{array}{c}\text { Aroclor } \\
1260 \\
\end{array}$ & \% Lipids \\
\hline BLK27 & $6 / 6 / 07$ & CHNCAT & $\mathrm{F}$ & 45.2 & 1078.8 & 13226 & 210 & 180 & 59 & 5.5 \\
\hline BLK27 & $6 / 6 / 07$ & CHNCAT & $\mathrm{F}$ & & & 13227 & 230 & 200 & 68 & 5.8 \\
\hline BLK31 & $6 / 6 / 07$ & CHNCAT & $\mathrm{M}$ & 40.2 & 665.2 & 13250 & 29 & 34 & 12 & 5.1 \\
\hline BLK31 & $6 / 6 / 07$ & CHNCAT & M & 33.2 & 342.3 & 13251 & 15 & 19 & $<11 \mathrm{iu}$ & 2.4 \\
\hline BLK31 & $6 / 6 / 07$ & CHNCAT & M & 36.5 & 502.0 & 13252 & 23 & 24 & 12 & 5 \\
\hline BLK31 & $6 / 6 / 07$ & CHNCAT & $\mathrm{F}$ & 37.1 & 575.9 & 13253 & $<11 \mathrm{iu}$ & 11 & $<11 \mathrm{iu}$ & 3.4 \\
\hline BLK31 & $6 / 6 / 07$ & CHNCAT & M & 36.0 & 430.0 & 13254 & $<11 \mathrm{iu}$ & 11 & $<11 \mathrm{iu}$ & 2.5 \\
\hline BLK31 & $6 / 6 / 07$ & CHNCAT & $\mathrm{F}$ & 41.0 & 737.1 & 13255 & 20 & 25 & $<11 \mathrm{iu}$ & 3.7 \\
\hline BLK31 & $6 / 6 / 07$ & CHNCAT & M & 46.7 & 983.7 & 13256 & 150 & 190 & 70 & 5.5 \\
\hline BLK31 & $6 / 6 / 07$ & CHNCAT & M & 48.0 & 1059.4 & 13257 & 20 & 20 & $<11 \mathrm{iu}$ & 4.6 \\
\hline ICK0.2 & $6 / 5 / 07$ & CHNCAT & $\mathrm{M}$ & 56.9 & 1892.7 & 13110 & 330 & 380 & 160 & 1 \\
\hline ICK0.2 & $6 / 5 / 07$ & CHNCAT & M & 43.8 & 711.9 & 13111 & 600 & 240 & $<22 \mathrm{iu}$ & 4.1 \\
\hline ICK0.2 & $6 / 5 / 07$ & CHNCAT & M & 45.3 & 827.3 & 13112 & 190 & 130 & $<110 \mathrm{iu}$ & 5.3 \\
\hline ICK 0.2 & $6 / 5 / 07$ & CHNCAT & $\mathrm{F}$ & 42.2 & 710.7 & 13113 & 52 & 63 & 39 & 2.7 \\
\hline ICK 0.2 & $6 / 5 / 07$ & CHNCAT & M & 41.2 & 548.8 & 13114 & 46 & 55 & 43 & 4.4 \\
\hline ICK 0.2 & $6 / 5 / 07$ & CHNCAT & $\mathrm{F}$ & 45.1 & 808.0 & 13115 & 110 & 140 & 110 & 4.3 \\
\hline ICK0.2 & $6 / 5 / 07$ & CHNCAT & M & 41.7 & 627.8 & 13116 & 60 & 60 & 38 & 2.7 \\
\hline ICK0.2 & $6 / 5 / 07$ & CHNCAT & $\mathrm{M}$ & 33.3 & 326.3 & 13117 & 310 & 140 & $<110 \mathrm{iu}$ & 2.9 \\
\hline ICK 1.0 & $6 / 5 / 07$ & CHNCAT & $M$ & 35.8 & 462.3 & 13210 & $<22$ iu & 46 & 30 & 3.3 \\
\hline ICK 1.0 & $6 / 5 / 07$ & CHNCAT & M & 45.0 & 818.0 & 13211 & $<11 \mathrm{iu}$ & $<11 \mathrm{iu}$ & $<11 \mathrm{iu}$ & 1.7 \\
\hline ICK 1.0 & $6 / 5 / 07$ & CHNCAT & M & 39.3 & 624.5 & 13212 & 160 & 140 & 69 & 3.2 \\
\hline ICK 1.0 & $6 / 5 / 07$ & CHNCAT & $\mathrm{F}$ & 45.4 & 1046.3 & 13213 & 160 & 120 & 60 & 2.1 \\
\hline ICK 1.0 & $6 / 5 / 07$ & CHNCAT & M & 51.0 & 1220.2 & 13214 & 63 & 68 & 41 & 4.8 \\
\hline ICK 1.0 & $6 / 5 / 07$ & CHNCAT & $\mathrm{F}$ & 47.0 & 1112.2 & 13215 & 350 & 250 & 140 & 6.4 \\
\hline ICK 1.0 & $6 / 5 / 07$ & CHNCAT & M & 50.2 & 1153.5 & 13216 & 34 & 48 & $<33 \mathrm{iu}$ & 4.6 \\
\hline ICK 1.0 & $6 / 5 / 07$ & CHNCAT & $\mathrm{F}$ & 55.7 & 1641.3 & 13217 & 0 & 34 & $<33 \mathrm{iu}$ & 2.8 \\
\hline ICK3.0 & $6 / 7 / 07$ & CHNCAT & $\mathrm{M}$ & 32.8 & 352.8 & 13271 & 38 & 26 & $<11 \mathrm{iu}$ & 4.2 \\
\hline ICK3.0 & $6 / 7 / 07$ & CHNCAT & M & 37.2 & 470.6 & 13272 & 18 & 24 & 11 & 3.8 \\
\hline ICK 3.0 & $6 / 7 / 07$ & CHNCAT & M & 38.5 & 546.5 & 13273 & 51 & 52 & 24 & 5.5 \\
\hline ICK 3.0 & $6 / 7 / 07$ & CHNCAT & $\mathrm{M}$ & 37.1 & 510.2 & 13274 & 90 & 88 & 44 & 4.2 \\
\hline ICK 3.0 & $6 / 7 / 07$ & CHNCAT & M & 42.5 & 762.4 & 13275 & 23 & 31 & 19 & 3.8 \\
\hline ICK 3.0 & $6 / 7 / 07$ & CHNCAT & M & 45.0 & 971.4 & 13276 & 27 & 36 & 20 & 3.2 \\
\hline ICK 3.0 & $6 / 7 / 07$ & CHNCAT & $\mathrm{F}$ & 48.5 & 1267.2 & 13277 & 46 & 42 & 21 & 3.2 \\
\hline ICK 3.0 & $6 / 7 / 07$ & CHNCAT & $\mathrm{F}$ & & & 13278 & 44 & 38 & $<22 \mathrm{iu}$ & 3 \\
\hline
\end{tabular}


Table A-2. (cont'd)

NA: Sex was not determined on fish comprising composite samples. Average length and weight of 3 fish composite sample was reported in this table.

Qualifiers:

$<$

iu

j

nd
Altered pattern

Aroclor analysis

Estimated concentration

non-detect for lipids
PCB peak pattern did not match fingerprint of Aroclor standards

Common in environmental samples; extra peaks observed

PCB concentration was below the reporting limit, a statistically-based value related to the quantitative confidence in the reported number

Actual detection limit is $10-20 \%$ of reporting limit

Value reported falls below reporting limit but above detection limit 
Table A-3. Congener-specific PCB concentrations (ng/g, wet wt) in individual green sunfish and channel catfish fillets and SPMD collected from sites on Indian Creek (ICK), Blue River (BLK), and Boone Creek (BCK) near the Kansas City Plant, July 2007

\begin{tabular}{|c|c|c|c|c|c|c|c|c|c|c|c|c|c|}
\hline \multirow{2}{*}{ Site } & \multirow{2}{*}{$\begin{array}{l}\text { Sample } \\
\text { number }\end{array}$} & \multirow{2}{*}{ Species } & \multicolumn{11}{|c|}{ PCB Congeners } \\
\hline & & & 77 & 81 & 105 & 114 & 118 & 123 & 126 & $156 / 157$ & 167 & 169 & 189 \\
\hline BLK25 & 13171 & GREENS & 0.12 & ND & 0.34 & 0.021 & 0.74 & 0.011 & ND & 0.072 & 0.025 & ND & ND \\
\hline BLK25 & 13172 & GREENS & 0.17 & ND & 0.71 & 0.058 & 1.4 & 0.034 & ND & 0.087 & 0.031 & ND & ND \\
\hline BLK25 & 13173 & GREENS & 0.16 & ND & 0.36 & 0.016 & 0.76 & 0.02 & 0.024 & 0.066 & 0.021 & ND & ND \\
\hline BLK25 & 13174 & GREENS & 0.11 & ND & 0.28 & 0.017 & 0.55 & 0.014 & ND & 0.048 & ND & ND & ND \\
\hline BLK25 & 13175 & GREENS & 0.47 & 0.026 & 1.4 & 0.12 & 3.2 & 0.08 & 0.055 & 0.23 & 0.09 & 0.023 & 0.021 \\
\hline BLK25 & 13176 & GREENS & 0.13 & ND & 0.29 & 0.02 & 0.64 & 0.014 & 0.013 & 0.059 & 0.025 & ND & ND \\
\hline BLK25 & 13177 & GREENS & 0.13 & ND & 0.32 & 0.019 & 0.75 & 0.013 & ND & 0.054 & 0.02 & ND & ND \\
\hline BLK25 & 13178 & GREENS & 0.12 & ND & 0.32 & 0.02 & 0.67 & 0.0088 & 0.018 & 0.036 & 0.017 & ND & 0.0075 \\
\hline BLK27 & 13240 & GREENS & 0.13 & ND & 0.32 & 0.018 & 0.73 & 0.017 & 0.02 & 0.054 & 0.023 & ND & 0.011 \\
\hline BLK27 & 13241 & GREENS & 0.044 & ND & 0.15 & ND & 0.39 & 0.0066 & 0.015 & 0.031 & 0.013 & ND & ND \\
\hline BLK27 & 13242 & GREENS & 0.084 & ND & 0.36 & 0.033 & 0.92 & 0.016 & 0.028 & 0.11 & 0.054 & ND & 0.016 \\
\hline BLK27 & 13243 & GREENS & 0.14 & ND & 0.36 & 0.022 & 0.75 & 0.022 & 0.015 & 0.061 & 0.024 & ND & ND \\
\hline BLK27 & 13244 & GREENS & 0.07 & ND & 0.22 & ND & 0.47 & 0.014 & 0.014 & 0.063 & 0.021 & ND & 0.011 \\
\hline BLK27 & 13245 & GREENS & 0.058 & ND & 0.21 & 0.013 & 0.5 & 0.012 & ND & 0.06 & 0.019 & ND & ND \\
\hline BLK27 & 13246 & GREENS & 0.086 & ND & 0.35 & 0.018 & 0.9 & 0.017 & ND & 0.064 & 0.024 & ND & ND \\
\hline BLK27 & 13247 & GREENS & 0.37 & 0.021 & 0.91 & 0.088 & 2.1 & 0.055 & 0.077 & 0.14 & 0.065 & ND & 0.026 \\
\hline BLK31 & 13280 & GREENS & ND & ND & 0.01 & ND & 0.027 & ND & ND & 0.0062 & ND & ND & ND \\
\hline BLK31 & 13281 & GREENS & 0.0099 & ND & 0.047 & ND & 0.13 & 0.0017 & ND & 0.017 & 0.0078 & ND & ND \\
\hline BLK31 & 13282 & GREENS & 0.083 & ND & 0.27 & 0.018 & 0.52 & 0.013 & ND & 0.032 & 0.011 & ND & ND \\
\hline BLK31 & 13283 & GREENS & ND & ND & 0.013 & ND & 0.038 & ND & ND & 0.0038 & ND & ND & ND \\
\hline BLK31 & 13284 & GREENS & ND & ND & 0.057 & ND & 0.15 & ND & ND & 0.011 & ND & ND & ND \\
\hline BLK31 & 13285 & GREENS & 0.01 & ND & 0.08 & 0.011 & 0.24 & 0.0041 & ND & 0.037 & 0.013 & ND & ND \\
\hline BLK31 & 13286 & GREENS & ND & ND & 0.017 & ND & 0.04 & ND & ND & ND & ND & ND & ND \\
\hline BLK31 & 13287 & GREENS & 0.0051 & ND & 0.038 & ND & 0.091 & ND & ND & 0.012 & ND & ND & ND \\
\hline ICK 0.2 & 13120 & GREENS & 0.15 & ND & 0.39 & 0.027 & 0.93 & 0.025 & ND & 0.042 & 0.024 & ND & ND \\
\hline ICK 0.2 & 13121 & GREENS & 1.3 & 0.089 & 3 & 0.35 & 5.8 & 0.18 & 0.046 & 0.22 & 0.087 & ND & 0.025 \\
\hline ICK0.2 & 13122 & GREENS & 0.025 & ND & 0.15 & 0.012 & 0.4 & 0.0055 & ND & 0.022 & 0.0091 & ND & ND \\
\hline ICK 0.2 & 13123 & GREENS & 0.048 & ND & 0.16 & 0.0088 & 0.37 & 0.016 & ND & 0.034 & 0.015 & ND & ND \\
\hline ICK0.2 & 13124 & GREENS & 0.027 & ND & 0.11 & ND & 0.27 & ND & ND & 0.036 & 0.016 & ND & ND \\
\hline ICK0.2 & 13125 & GREENS & 0.12 & ND & 0.23 & 0.019 & 0.69 & 0.011 & ND & 0.023 & 0.0086 & ND & ND \\
\hline ICK0.2 & 13126 & GREENS & 0.1 & ND & 0.36 & 0.034 & 0.73 & 0.019 & ND & 0.042 & 0.017 & ND & ND \\
\hline ICK0.2 & 13127 & GREENS & 0.067 & ND & 0.13 & 0.011 & 0.37 & 0.011 & ND & 0.042 & 0.016 & ND & ND \\
\hline
\end{tabular}


Table A-3. (cont'd)

\begin{tabular}{|c|c|c|c|c|c|c|c|c|c|c|c|c|c|}
\hline \multirow{2}{*}{ Site } & \multirow{2}{*}{$\begin{array}{l}\text { Sample } \\
\text { number }\end{array}$} & \multirow{2}{*}{ Species } & \multicolumn{11}{|c|}{ PCB Congeners } \\
\hline & & & 77 & 81 & 105 & 114 & 118 & 123 & 126 & $156 / 157$ & 167 & 169 & 189 \\
\hline ICK 1.0 & 12890 & GREENS & 0.083 & ND & 0.19 & 0.014 & 0.41 & 0.01 & ND & 0.029 & 0.0066 & ND & ND \\
\hline ICK 1.0 & 12891 & GREENS & ND & ND & 0.049 & ND & 0.13 & ND & ND & 0.015 & ND & ND & ND \\
\hline ICK 1.0 & 12892 & GREENS & 0.16 & 0.0074 & 0.38 & 0.029 & 0.92 & 0.022 & 0.017 & 0.085 & 0.035 & ND & ND \\
\hline ICK 1.0 & 12893 & GREENS & 0.086 & ND & 0.22 & 0.015 & 0.45 & 0.012 & ND & 0.025 & 0.011 & ND & ND \\
\hline ICK 1.0 & 12894 & GREENS & 0.087 & ND & 0.37 & 0.028 & 0.82 & 0.027 & 0.014 & 0.058 & 0.027 & ND & ND \\
\hline ICK 1.0 & 12895 & GREENS & 0.0074 & ND & 0.044 & ND & 0.16 & 0.0029 & ND & 0.019 & 0.0057 & ND & ND \\
\hline ICK 1.0 & 12896 & GREENS & 0.032 & ND & 0.18 & ND & 0.42 & 0.0092 & ND & 0.031 & 0.015 & ND & ND \\
\hline ICK 1.0 & 12897 & GREENS & ND & ND & 0.091 & ND & 0.24 & ND & ND & 0.036 & 0.014 & ND & ND \\
\hline ICK 3.0 & 13190 & GREENS & ND & ND & 0.023 & ND & 0.073 & ND & ND & ND & ND & ND & ND \\
\hline ICK 3.0 & 13191 & GREENS & ND & ND & 0.018 & 0.0023 & 0.052 & ND & ND & ND & ND & ND & ND \\
\hline ICK 3.0 & 13192 & GREENS & ND & ND & 0.038 & ND & 0.11 & ND & ND & ND & ND & ND & ND \\
\hline ICK 3.0 & 13194 & GREENS & ND & ND & 0.025 & ND & 0.068 & ND & ND & ND & ND & ND & ND \\
\hline ICK 3.0 & 13195 & GREENS & ND & ND & 0.13 & 0.0089 & 0.33 & ND & ND & 0.052 & 0.012 & ND & ND \\
\hline ICK 3.0 & 13196 & GREENS & ND & ND & 0.059 & ND & 0.13 & ND & ND & 0.028 & ND & ND & ND \\
\hline ICK 3.0 & 13197 & GREENS & ND & ND & 0.033 & ND & 0.078 & ND & ND & ND & ND & ND & ND \\
\hline ICK 3.0 & 13198 & GREENS & ND & ND & 0.037 & ND & 0.11 & ND & ND & 0.016 & ND & ND & ND \\
\hline BLK25 & 13150 & CHNCAT & 0.09 & ND & 2.6 & 0.16 & 6.3 & 0.13 & 0.18 & 0.45 & 0.21 & ND & 0.053 \\
\hline BLK25 & 13151 & CHNCAT & ND & ND & 4.5 & 0.45 & 11 & 0.22 & 0.23 & 0.7 & 0.28 & ND & 0.086 \\
\hline BLK25 & 13152 & CHNCAT & ND & ND & 4.5 & 0.28 & 11 & 0.29 & 0.15 & 0.66 & 0.34 & ND & ND \\
\hline BLK25 & 13153 & CHNCAT & 0.082 & ND & 2.7 & 0.25 & 6.7 & 0.15 & 0.13 & 0.44 & 0.22 & ND & 0.045 \\
\hline BLK25 & 13154 & CHNCAT & 0.062 & 0.019 & 3.2 & 0.28 & 8.4 & 0.18 & 0.19 & 0.54 & 0.28 & 0.046 & 0.053 \\
\hline BLK25 & 13155 & CHNCAT & 0.074 & 0.026 & 2.5 & 0.22 & 6.3 & 0.17 & 0.079 & 0.38 & 0.22 & ND & 0.049 \\
\hline BLK25 & 13156 & CHNCAT & ND & ND & 0.16 & 0.012 & 0.4 & 0.014 & ND & 0.044 & 0.022 & ND & ND \\
\hline BLK25 & 13157 & CHNCAT & 0.13 & 0.042 & 3.9 & 0.34 & 11 & 0.3 & 0.17 & 0.94 & 0.5 & ND & 0.12 \\
\hline BLK27 & 13220 & CHNCAT & 0.13 & 0.09 & 7.4 & 0.55 & 20 & 0.51 & 0.16 & 1.1 & 0.61 & 0.068 & 0.061 \\
\hline BLK27 & 13221 & CHNCAT & 0.075 & 0.046 & 3.8 & 0.35 & 10 & 0.21 & 0.078 & 0.93 & 0.4 & 0.03 & 0.058 \\
\hline BLK27 & 13222 & CHNCAT & 0.07 & 0.023 & 2.3 & 0.21 & 6.1 & 0.16 & 0.061 & 0.6 & 0.24 & 0.019 & 0.029 \\
\hline BLK27 & 13223 & CHNCAT & 0.076 & 0.026 & 3.2 & 0.23 & 8.5 & 0.18 & 0.13 & 0.74 & 0.31 & 0.025 & 0.047 \\
\hline BLK27 & 13224 & CHNCAT & 0.087 & 0.022 & 3.3 & 0.28 & 8.8 & 0.21 & 0.11 & 0.89 & 0.38 & 0.038 & 0.061 \\
\hline BLK27 & 13225 & CHNCAT & 0.054 & 0.023 & 2 & 0.16 & 5.7 & 0.095 & 0.074 & 0.58 & 0.24 & 0.029 & 0.037 \\
\hline BLK27 & 13226 & CHNCAT & 0.13 & 0.058 & 4.7 & 0.38 & 12 & 0.29 & 0.13 & 1 & 0.42 & 0.044 & 0.064 \\
\hline BLK27 & 13227 & CHNCAT & 0.094 & 0.035 & 5.3 & 0.39 & 13 & 0.31 & 0.13 & 1.1 & 0.43 & 0.037 & 0.078 \\
\hline
\end{tabular}


Table A-3. (cont'd)

\begin{tabular}{|c|c|c|c|c|c|c|c|c|c|c|c|c|c|}
\hline \multirow{2}{*}{ Site } & \multirow{2}{*}{$\begin{array}{l}\text { Sample } \\
\text { number }\end{array}$} & \multirow{2}{*}{ Species } & \multicolumn{11}{|c|}{ PCB Congeners } \\
\hline & & & 77 & 81 & 105 & 114 & 118 & 123 & 126 & $156 / 157$ & 167 & 169 & 189 \\
\hline BLK31 & 13250 & CHNCAT & ND & ND & 0.76 & 0.065 & 1.7 & 0.03 & 0.013 & 0.13 & 0.065 & ND & ND \\
\hline BLK31 & 13251 & CHNCAT & ND & ND & 0.55 & 0.059 & 1.2 & 0.05 & ND & 0.12 & 0.062 & ND & ND \\
\hline BLK31 & 13252 & CHNCAT & ND & ND & 0.64 & 0.033 & 1.5 & 0.028 & 0.011 & 0.12 & 0.05 & ND & 0.011 \\
\hline BLK31 & 13253 & CHNCAT & ND & ND & 0.38 & 0.023 & 0.94 & 0.016 & ND & 0.073 & 0.03 & ND & ND \\
\hline BLK31 & 13254 & CHNCAT & ND & ND & 0.24 & 0.017 & 0.56 & 0.011 & ND & 0.047 & 0.03 & ND & ND \\
\hline BLK31 & 13255 & CHNCAT & ND & ND & 0.15 & ND & 0.44 & ND & ND & 0.027 & ND & ND & ND \\
\hline BLK31 & 13256 & CHNCAT & 0.097 & 0.035 & 5.3 & 0.34 & 15 & 0.33 & 0.18 & 1.6 & 0.63 & 0.055 & 0.09 \\
\hline BLK31 & 13257 & CHNCAT & 0.0083 & 0.013 & 0.61 & 0.043 & 1.3 & 0.026 & 0.0086 & 0.094 & 0.037 & ND & ND \\
\hline ICK 0.2 & 13110 & CHNCAT & 0.099 & 0.062 & 4 & 0.41 & 10 & 0.31 & 0.11 & 1.4 & 0.55 & ND & 0.13 \\
\hline ICK 0.2 & 13111 & CHNCAT & 0.2 & 0.17 & 6.1 & 0.63 & 13 & 0.43 & 0.18 & 0.81 & 0.34 & ND & 0.11 \\
\hline ICK 0.2 & 13112 & CHNCAT & 0.067 & 0.028 & 1.8 & 0.17 & 4.2 & 0.12 & 0.047 & 0.33 & 0.15 & ND & 0.034 \\
\hline ICK 0.2 & 13113 & CHNCAT & 0.041 & 0.013 & 1.3 & 0.11 & 3.6 & 0.086 & 0.072 & 0.39 & 0.19 & 0.029 & 0.058 \\
\hline ICK0.2 & 13114 & CHNCAT & ND & ND & 0.59 & 0.04 & 1.6 & 0.049 & 0.047 & 0.22 & 0.11 & ND & 0.036 \\
\hline ICK 0.2 & 13115 & CHNCAT & 0.062 & 0.026 & 2 & 0.18 & 5.1 & 0.078 & 0.12 & 0.65 & 0.33 & ND & 0.12 \\
\hline ICK 0.2 & 13116 & CHNCAT & 0.03 & ND & 1.5 & 0.15 & 4.4 & 0.08 & 0.069 & 0.76 & 0.31 & ND & 0.053 \\
\hline ICK0.2 & 13117 & CHNCAT & 0.13 & 0.098 & 3.2 & 0.38 & 6.6 & 0.22 & 0.085 & 0.48 & 0.2 & ND & 0.053 \\
\hline ICK 1.0 & 13210 & CHNCAT & ND & ND & 0.37 & 0.032 & 1 & 0.022 & 0.042 & 0.16 & 0.068 & 0.017 & 0.023 \\
\hline ICK 1.0 & 13211 & CHNCAT & ND & ND & 0.058 & ND & 0.17 & ND & ND & 0.023 & ND & ND & ND \\
\hline ICK 1.0 & 13212 & CHNCAT & 0.051 & 0.03 & 2.3 & 0.24 & 5.9 & 0.15 & 0.12 & 0.47 & 0.24 & 0.057 & 0.054 \\
\hline ICK 1.0 & 13213 & CHNCAT & 0.054 & 0.019 & 2.2 & 0.2 & 6.1 & 0.17 & 0.092 & 0.44 & 0.24 & 0.029 & 0.044 \\
\hline ICK 1.0 & 13214 & CHNCAT & 0.019 & ND & 1 & 0.088 & 2.7 & 0.041 & 0.023 & 0.27 & 0.1 & ND & 0.034 \\
\hline ICK 1.0 & 13215 & CHNCAT & 0.088 & 0.089 & 4.3 & 0.43 & 12 & 0.33 & 0.2 & 0.77 & 0.41 & ND & 0.068 \\
\hline ICK 1.0 & 13216 & CHNCAT & 0.012 & ND & 0.68 & 0.06 & 1.9 & 0.027 & 0.03 & 0.27 & 0.1 & ND & 0.019 \\
\hline ICK 1.0 & 13217 & CHNCAT & ND & ND & 0.57 & 0.049 & 1.8 & 0.035 & 0.056 & 0.29 & 0.17 & ND & 0.056 \\
\hline ICK 3.0 & 13271 & CHNCAT & 0.027 & 0.013 & 2.2 & 0.16 & 5.3 & 0.089 & 0.016 & 0.46 & 0.12 & ND & 0.0092 \\
\hline ICK 3.0 & 13272 & CHNCAT & ND & ND & 0.27 & 0.019 & 0.75 & 0.013 & 0.02 & 0.082 & 0.032 & ND & ND \\
\hline ICK 3.0 & 13273 & CHNCAT & ND & ND & 0.43 & 0.038 & 1.3 & 0.017 & ND & 0.12 & 0.066 & ND & ND \\
\hline ICK 3.0 & 13274 & CHNCAT & 0.02 & 0.011 & 1.6 & 0.13 & 4.3 & 0.1 & 0.046 & 0.3 & 0.15 & ND & 0.025 \\
\hline ICK 3.0 & 13275 & CHNCAT & ND & ND & 0.37 & 0.021 & 1.1 & 0.015 & 0.015 & 0.1 & 0.041 & ND & 0.011 \\
\hline ICK 3.0 & 13276 & CHNCAT & ND & ND & 0.4 & 0.031 & 1.1 & 0.017 & 0.017 & 0.12 & 0.043 & ND & 0.014 \\
\hline ICK 3.0 & 13277 & CHNCAT & ND & ND & 0.56 & 0.047 & 1.4 & 0.027 & 0.016 & 0.14 & 0.055 & ND & 0.015 \\
\hline ICK 3.0 & 13278 & CHNCAT & ND & ND & 0.55 & 0.038 & 1.4 & 0.036 & 0.016 & 0.15 & 0.059 & ND & 0.01 \\
\hline
\end{tabular}


Table A-3. (cont'd)

\begin{tabular}{|c|c|c|c|c|c|c|c|c|c|c|c|c|c|}
\hline \multirow{2}{*}{ Site } & \multirow{2}{*}{$\begin{array}{l}\text { Sample } \\
\text { number }\end{array}$} & \multirow{2}{*}{ Species } & \multicolumn{11}{|c|}{ PCB Congeners } \\
\hline & & & 77 & 81 & 105 & 114 & 118 & 123 & 126 & $156 / 157$ & 167 & 169 & 189 \\
\hline ВCK0.2 & 12967 & GREENS & 0.32 & ND & 1.5 & 0.11 & 3.7 & 0.069 & ND & 0.36 & 0.1 & ND & ND \\
\hline BCK 0.2 & 12968 & GREENS & 0.54 & ND & 4.1 & 0.32 & 11 & 0.11 & ND & 1.3 & 0.34 & ND & 0.044 \\
\hline BCK 0.2 & 12969 & GREENS & 0.3 & ND & 1.8 & 0.11 & 4.3 & 0.058 & 0.037 & 0.39 & 0.11 & ND & ND \\
\hline $\begin{array}{l}\text { Boone- } \\
\text { up }\end{array}$ & 12587 & SPMD & 7.2 & 0.3 & 20 & 1.3 & 51 & 0.81 & 0.2 & 2.1 & 0.7 & ND & 0.055 \\
\hline OF 001 & $12938 \mathrm{~A}$ & SPMD & 11 & 0.38 & 37 & 2.8 & 100 & 1.6 & 0.27 & 5.3 & 1.9 & ND & 0.11 \\
\hline $\begin{array}{l}\text { Boone- } \\
\text { down }\end{array}$ & 12739 & SPMD & 9.8 & 0.52 & 19 & 1.7 & 52 & 1.1 & 0.26 & 1.9 & 0.82 & ND & 0.093 \\
\hline ICK 3.0 & 12937 & SPMD & 0.74 & 0.065 & 12 & 1.1 & 40 & 0.88 & 0.061 & 0 & 0.42 & ND & ND \\
\hline OF 003 & $12589 \mathrm{~A}$ & SPMD & 1.8 & 0.043 & 25 & 2.1 & 100 & 1.5 & 0.18 & 2.8 & 1 & ND & 0.054 \\
\hline ICK 1.0 & 12768 & SPMD & 0.9 & ND & 7.9 & 0.55 & 21 & 0.31 & ND & 1.6 & 0.56 & ND & ND \\
\hline OF 002 & 12939 & SPMD & 13 & 0.63 & 34 & 2.7 & 93 & 1.6 & 0.34 & 3.6 & 1.5 & ND & 0.13 \\
\hline ICK 0.2 & 12737 & SPMD & 2.6 & 0.14 & 9.4 & 0.77 & 27 & 0.38 & ND & 0.93 & 0.37 & ND & ND \\
\hline BLK 31 & 12738 & SPMD & 1.1 & 0 & 20 & 1.9 & 73 & 0.93 & ND & 1.7 & 0.65 & ND & ND \\
\hline BLK 25 & 12769 & SPMD & 5.2 & 0.22 & 12 & 1.1 & 33 & 2.7 & 0.088 & 1.1 & 0.48 & ND & ND \\
\hline OF 003 & 12589B & SPMD & 1.9 & 0.14 & 45 & 3.9 & 160 & 2.1 & 0.64 & 4.6 & 1.9 & ND & 0.093 \\
\hline OF 001 & 12938B & SPMD & 10 & 0.45 & 41 & 2.8 & 120 & 1.7 & 0.26 & 5.7 & 2.1 & ND & 0.081 \\
\hline $\begin{array}{l}\text { Trip } \\
\text { blank }\end{array}$ & 12767 & SPMD & 2.4 & 0.08 & 17 & 1.3 & 51 & 0.74 & 0.13 & 1.9 & 0.76 & ND & ND \\
\hline ICK0.2 & 12737B & SPMD & 0.92 & ND & 6.9 & 0.39 & 19 & 0.35 & ND & 0.65 & 0.21 & ND & ND \\
\hline ICK 1.0 & 12768B & SPMD & 1.1 & 0.038 & 9.5 & 0.66 & 31 & 0.45 & 0.085 & 1.1 & 0.44 & ND & ND \\
\hline BCK 0.5 & 13610 & SPMD & 1.4 & ND & 5.3 & 0.36 & 12 & 0.19 & ND & 0.63 & 0.18 & ND & ND \\
\hline BCK 0.2 & 13611 & SPMD & 1.3 & 0.071 & 4.2 & 0.29 & 10 & 0.25 & ND & 0.53 & 0.15 & ND & ND \\
\hline $\begin{array}{l}\text { BCK0.4 } \\
\text { trip }\end{array}$ & 13612 & SPMD & 0.91 & ND & 2.7 & 0.13 & 6.8 & 0.092 & ND & 0.2 & ND & ND & ND \\
\hline blank & 13613 & SPMD & 0.51 & ND & 11 & 0.76 & 33 & 0.49 & ND & 0.8 & 0.23 & ND & ND \\
\hline OF001 & 13614 & SPMD & 1.7 & 0.073 & 5.6 & 0.31 & 14 & 0.35 & ND & 0.65 & 0.24 & ND & ND \\
\hline BCK 0.7 & 13615 & SPMD & 0.74 & 0.03 & 2.6 & 0.12 & 6 & 0.095 & ND & 0.31 & 0.092 & ND & ND \\
\hline BCK0.3 & 13616 & SPMD & 1.2 & ND & 3.2 & 0.21 & 6.8 & 0.13 & ND & 0.33 & 0.097 & ND & ND \\
\hline
\end{tabular}




\section{APPENDIX B QUALITY ASSURANCE SUMMARY}





\section{Quality Assurance Summary}

Test results from the fish tissue and SPMD analyses met all applicable NELAC requirements. Due to sample matrix interferences in some samples, estimated results below the reporting limit were not reported for some analytes for most samples. Also, due to limited sample volumes in some samples, a laboratory control sample/laboratory control sample duplicate was performed instead of a matrix spike/matrix spike duplicate. Extremely altered patterns of PCBs were observed, as well as additional peaks not belonging to a clear Aroclor pattern. Most of the Aroclors were identified as 1248 and 1254 because the heaviest concentration of peaks eluted within the retention time area of the Aroclor 1248 and 1254 standards. The reporting limits for the other Aroclors were elevated.

Duplicate fish sample runs were deemed acceptable. Low-PCB reference fish samples were also within a normal and expected range very near analytical detection limits. For 20 of the most often detected congeners, a ratio of the original value to duplicate value was calculated for each duplicate pair. Of the 10 duplicate fish samples all but two of the ratios were generally around 1 as expected (Figure B-1). The poorest replication of results was for two sunfish samples - one with moderate values (BLK27) and one with barely detectable values (ICK3.0).

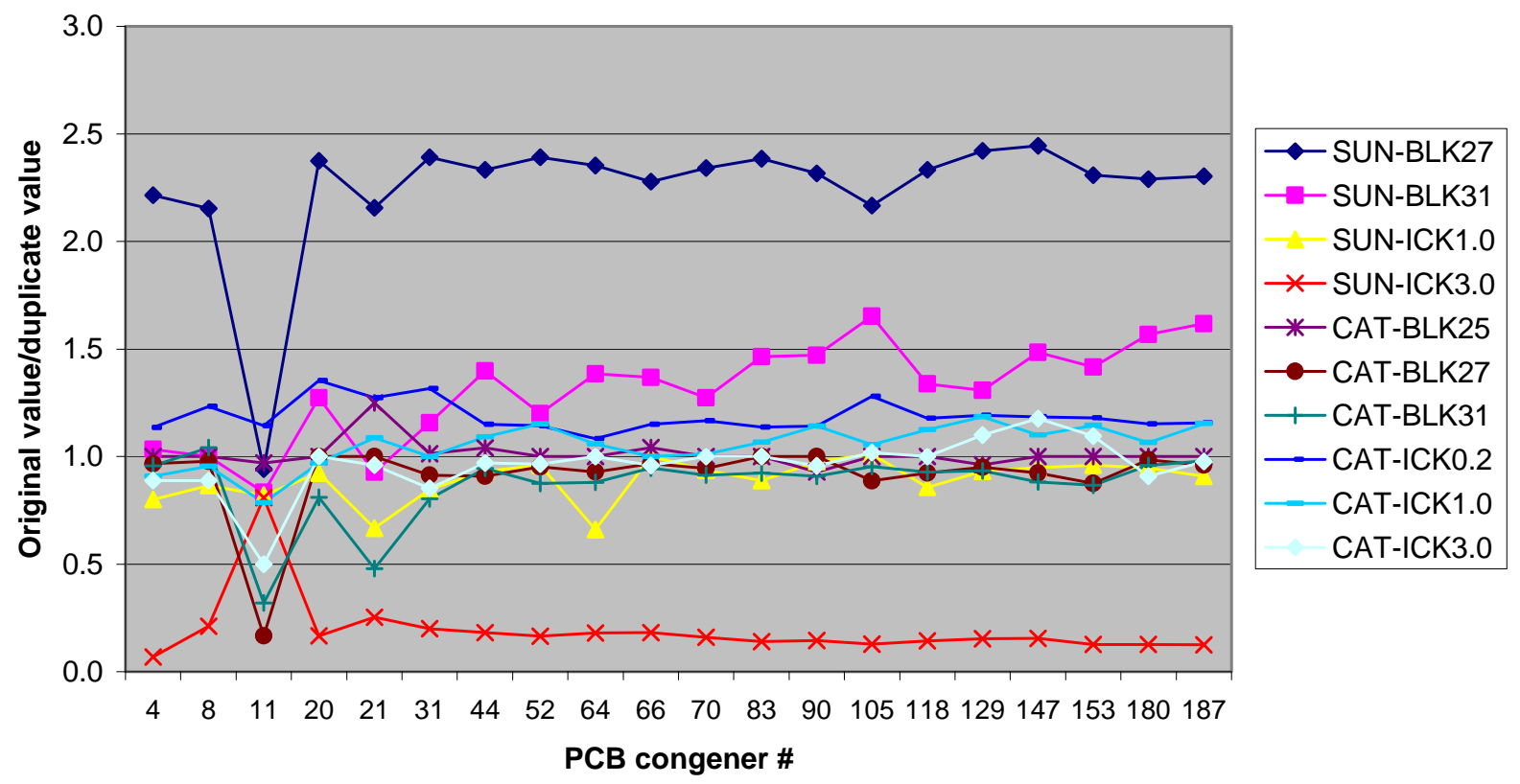

Fig. B-1. Ratio of original to duplicate result for 20 PCB congeners for 10 pairs of duplicate fish samples.

The high PCBs found in SPMD blanks was undesirable, although when subtracted from site SPMD concentrations the results did provide site differences not inconsistent with expectations. That said, given the variability in PCB analyses and the many factors that affect PCB uptake in SPMDs, only the results substantially higher than the blank concentrations should be considered definitive.

The high resolution gas chromatography/mass spectrometry procedure used for analysis of PCB congeners uses a C-13 isotopically labeled internal standard for each congener being quantified. Quantitative identification of weathered PCBs at concentrations near analytical detection limits is problematic, especially if other chlorinated compounds are present. Previous monitoring at KCP has 
found peak patterns of PCB extracts from biota to be atypical of the PCB standards against which they are quantified, and commonly identified different Aroclors (1242 vs 1248, 1254 vs 1260) in different monitoring campaigns. The 2007 data also exhibited a highly altered PCB patterns and the presence of interferences. However, the highly specific HRGC/HRMS analysis of coplanar PCB clearly confirms that material identified as PCBs in Aroclor analysis was indeed PCBs. 


\section{INTERNAL DISTRIBUTION}

1-44. M. J. Peterson

45. L. Liang

46. S. D. Wullschleger

47-48. ESD Library

49. ORNL Office of Technical Information and Classification

\section{EXTERNAL DISTRIBUTION}

50. Michael Stites, Honeywell FM\&T, D/SE1, OD48, 2000 East 95th Street Kansas City, MO 641416159 